\title{
Hydraulic, Water-Quality, and Temperature Performance of Three Types of Permeable Pavement under High Sediment Loading Conditions
}

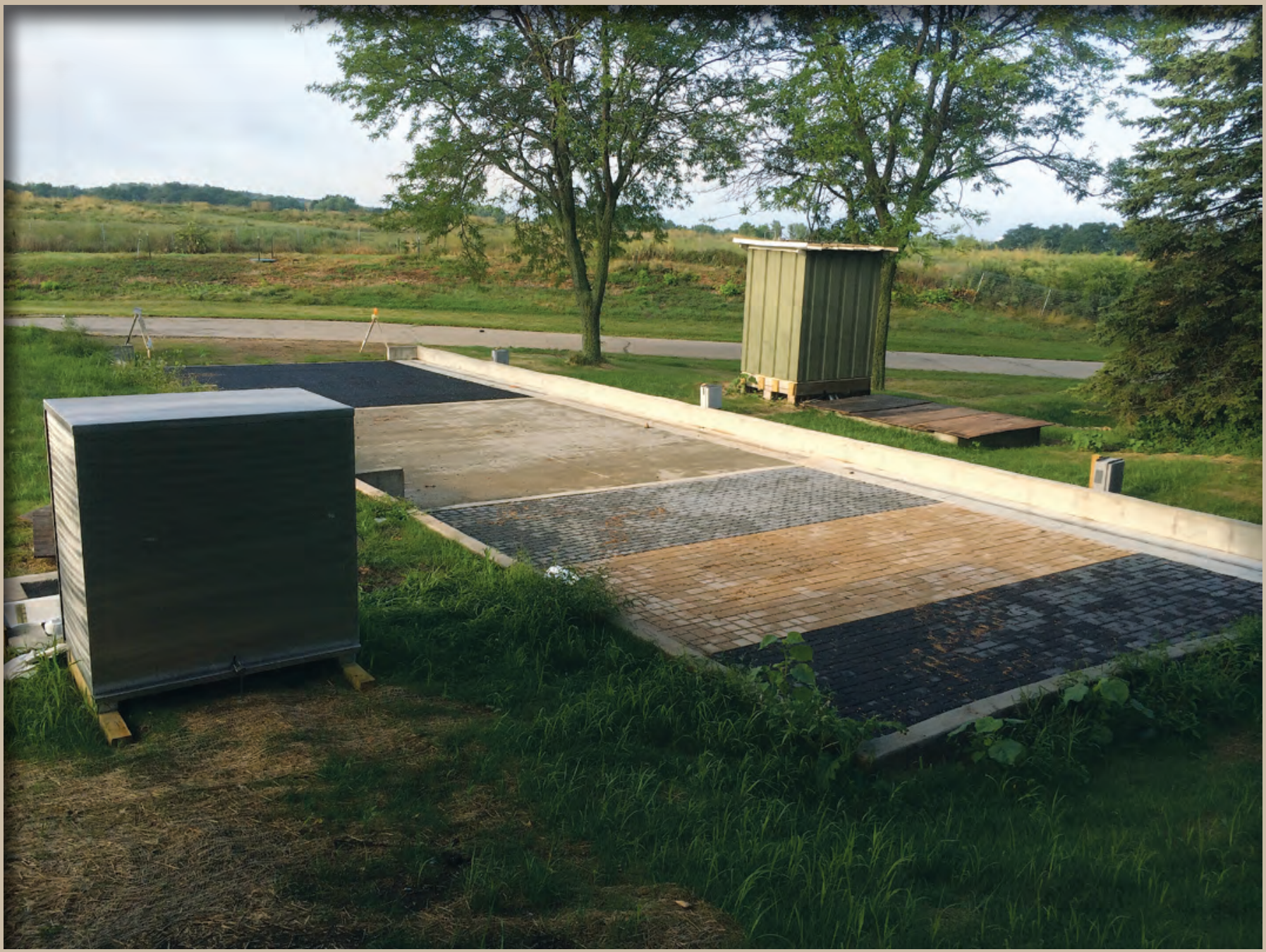

Scientific Investigations Report 2018-5037

U.S. Department of the Interior

U.S. Geological Survey 



\section{Hydraulic, Water-Quality, and Temperature Performance of Three Types of Permeable Pavement under High Sediment Loading Conditions}

By William R. Selbig and Nicolas Buer

Scientific Investigations Report 2018-5037 


\title{
U.S. Department of the Interior \\ Ryan K. Zinke, Secretary
}

\section{U.S. Geological Survey William H. Werkheiser, exercising the authority of the Director}

\author{
U.S. Geological Survey, Reston, Virginia: 2018
}

For more information on the USGS - the Federal source for science about the Earth, its natural and living resources, natural hazards, and the environment-visit https://www.usgs.gov or call 1-888-ASK-USGS.

For an overview of USGS information products, including maps, imagery, and publications, visit https://store.usgs.gov.

Any use of trade, firm, or product names is for descriptive purposes only and does not imply endorsement by the U.S. Government.

Although this information product, for the most part, is in the public domain, it also may contain copyrighted materials as noted in the text. Permission to reproduce copyrighted items must be secured from the copyright owner.

Suggested citation:

Selbig, W.R., and Buer, Nicolas, 2018, Hydraulic, water-quality, and temperature performance of three types of permeable pavement under high sediment loading conditions: U.S. Geological Survey Scientific Investigations Report 2018-5037, 44 p., https://doi.org/10.3133/sir20185037.

ISSN 2328-0328 (online) 


\section{Acknowledgments}

The authors would like to thank Roger Bannerman of the Wisconsin Department of Natural Resources (retired) and Bob Roehrig of County Materials Corporation for initiating and supporting this research effort; John McCarthy of Graef Engineering for designing the research facility; Chris Homburg of Homburg Construction for providing technical input and for leading the excavation and construction of the research facility; and Greg Fries and Tim Troester of the city of Madison for dedicating a portion of city property to locate the facility and for providing technical assistance. The authors also would like to thank Oldcastle Inc., Unilock, County Materials Corporation, Rock Roads, and Homburg Construction for donating materials and labor to install the permeable interlocking pavers, porous asphalt, and pervious concrete, respectively. The Wisconsin Department of Natural Resources, Wisconsin Department of Transportation, and County Materials Corporation provided financial support. Without the cooperation and effort of these individuals, agencies, and companies, this study would not have been possible. 



\section{Contents}

Acknowledgments ..................................................................................................................ii

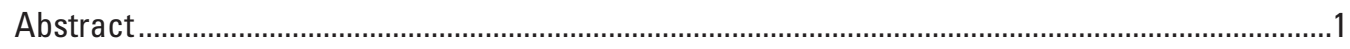

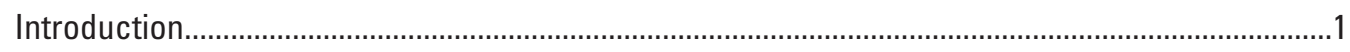

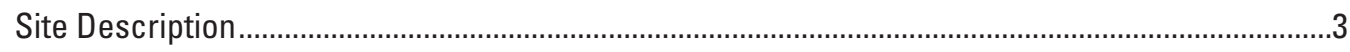

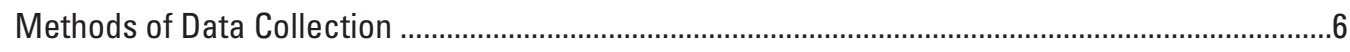

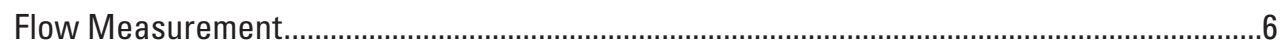

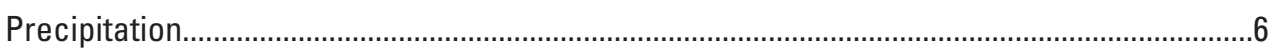

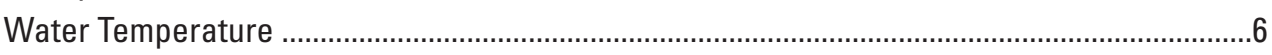

Runoff Sample Collection and Analyses ..............................................................................

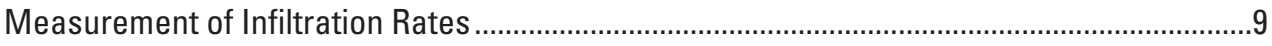

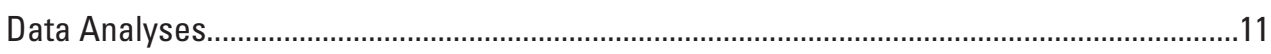

Quality Assurance and Quality Control ...................................................................................11

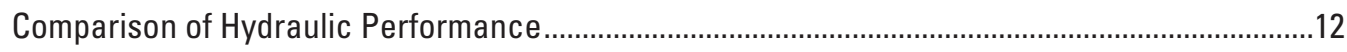

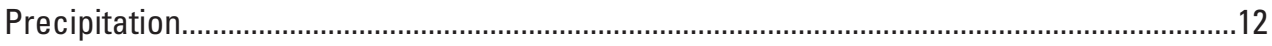

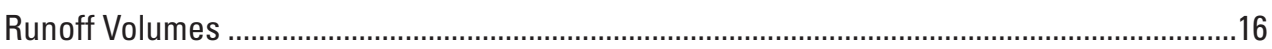

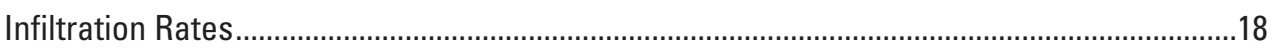

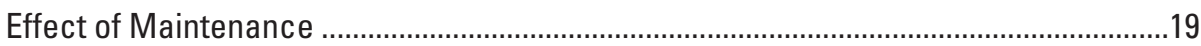

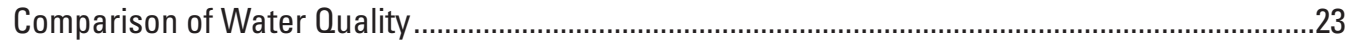

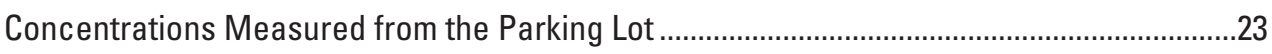

Concentrations Measured in the Underdrain .......................................................................2

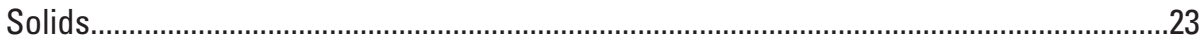

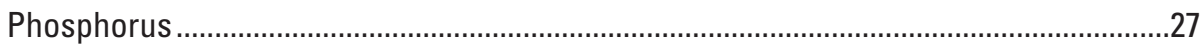

Chloride

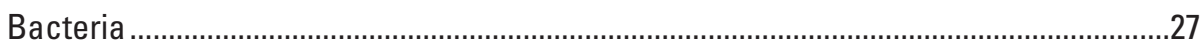

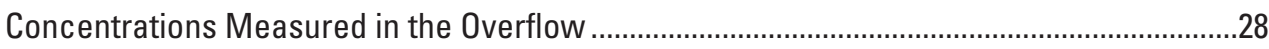

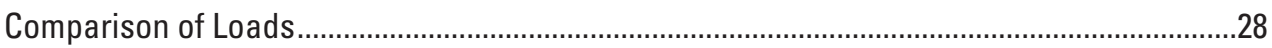

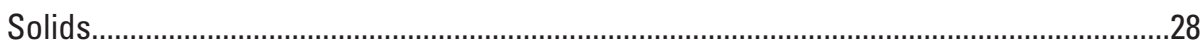

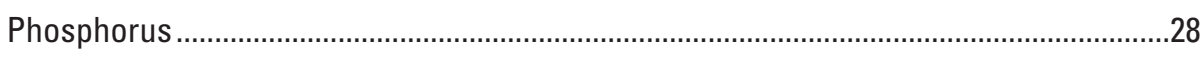

Chloride

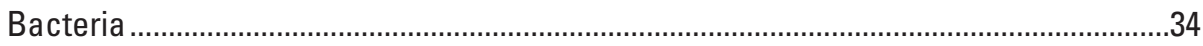

Combined Effect of Underdrain and Overflow .............................................................34

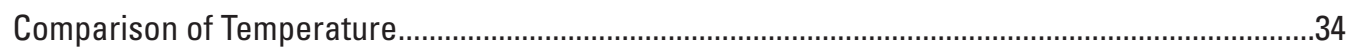

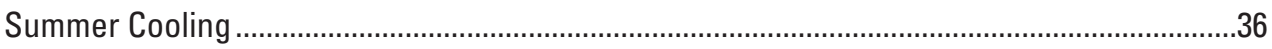

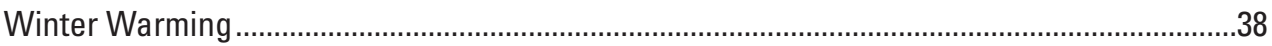

Summary and Conclusions.................................................................................................... 40

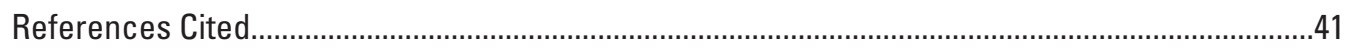




\section{Figures}

1. Map and corresponding aerial photograph showing $A$, location of permeable pavement research facility in Madison, Wisconsin, and $B$, schematic of drainage area and orientation of permeable pavements

2. Conceptual diagram showing cross-sectional profile of porous asphalt, pervious concrete, and permeable interlocking pavers test surfaces and aggregate base

3. Photographs showing hydraulic structures used to $A$, measure and distribute the flow of runoff from the parking lot; $B$, uniformly spread runoff across the test surface; and $C$, measure runoff that either passes through the underdrain of each permeable surface or bypasses as overflow

4. Photograph showing a network of temperature sensors placed in the porous asphalt test plot prior to installation of the aggregate base and asphalt surface.............8

5. Photographic illustration of device used to measure infiltration rates of porous asphalt, pervious concrete, and permeable interlocking pavers based on a modified version of ASTM C1701.

6. Graph showing monthly precipitation depth measured at the permeable pavement research facility from September 2014 through September 2016 compared to the 30-year normal (1981-2010)

7. Box plots showing seasonal precipitation depth and intensity for monitored events at the permeable pavement research facility.

8. Photograph showing zone of concentrated flow for runoff in the pervious concrete test plot.

9. Histogram showing the frequency of measurable runoff bypassing as overflow in the porous asphalt, pervious concrete, and permeable interlocking pavers test plots with increasing event precipitation depth

10. Graph showing the cumulative influent runoff volume measured from the parking lot compared to the cumulative effluent volume measured in the underdrains of the porous asphalt, pervious concrete, and permeable interlocking pavers test plots

11. Heat map illustrating spatial distribution of infiltration rates in the porous asphalt, pervious concrete, and permeable interlocking pavers test plots, in plan view, from 1 month to about 1 year after construction.

12. Chart and corresponding photograph showing response in infiltration rates at select locations premaintenance and postmaintenance of the pervious concrete surface

13. Chart and corresponding photograph showing spatial variation in infiltration rates before and after surface cleaning in the permeable interlocking pavers test plot.

14. Photograph of the profile of sediment captured into the aggregate used between the joints of the permeable interlocking pavers test surface.

15. Photograph of unmonitored sources of nutrients, seen here as the deposition of leaves from nearby trees, could potentially lead to effluent concentrations of dissolved phosphorus that are higher than the influent.

16. Graphs showing typical response to changing air temperatures at 0 (top), 6 (middle), and 12 (bottom) inches below the porous asphalt, pervious concrete, and permeable interlocking pavers surfaces during summer 
17. Graph showing influence of permeable pavement type on water temperature measured in the underdrains of the porous asphalt, pervious concrete, and permeable interlocking pavers test plots during a typical summer storm in June 2015

18. Graphs showing typical response to changing air temperature at 0 (top), 6 (middle), and 12 (bottom) inches below the porous asphalt, pervious concrete, and permeable interlocking pavers surfaces during winter

\section{Tables}

1. Constituents analyzed in influent and effluent runoff at the permeable pavement test site, Madison, Wisconsin.

2. Quality assurance sample results from the permeable pavement research facility in Madison, Wisconsin

3. Summary statistics for monitored and sampled precipitation events by month

4. Summary statistics of runoff volume that filtered through to the underdrain or bypassed as overflow in the porous asphalt, pervious concrete, and permeable interlocking pavers test plots.

5. Average surface infiltration rates in the porous asphalt, pervious concrete, and permeable interlocking pavers test plots

6. Summary statistics of event mean concentrations for pollutants measured from the parking lot and the underdrain and overflow monitoring points in the porous asphalt, pervious concrete, and permeable interlocking pavers test plots

7. Comparison of median effluent event mean concentrations of total suspended solids, total phosphorus, and chloride in porous asphalt, pervious concrete, and permeable interlocking pavers from select previous studies.

8. Decreasing concentrations of total suspended solids measured in the underdrain with time when surfaces of porous asphalt, pervious concrete, and permeable interlocking pavers were flushed with water from a nearby fire hydrant, September 18, 2014

9. Pearson correlation coefficients of chloride and total suspended solids concentrations in parking lot influent and porous asphalt, pervious concrete, and permeable interlocking pavers underdrain effluent

10. Summary statistics of pollutant loads with calculated removal efficiencies and statistical significance at the underdrain and overflow monitoring points in the porous asphalt, pervious concrete, and permeable interlocking pavers test plots.

11. Removal efficiency of each permeable pavement when loads measured in the underdrain and overflow effluent were combined 


\section{Conversion Factors}

U.S. customary units to International System of Units

\begin{tabular}{lcl}
\hline \multicolumn{1}{c}{ Multiply } & By & \multicolumn{1}{c}{ To obtain } \\
\hline inch (in.) & Length & \\
inch (in.) & 2.54 & centimeter $(\mathrm{cm})$ \\
inch (in.) & 25.4 & millimeter $(\mathrm{mm})$ \\
foot (ft) & 25,400 & micrometer $(\mu \mathrm{m})$ \\
\hline & 0.3048 & meter $(\mathrm{m})$ \\
\hline acre & Area & \\
acre & 4,047 & square meter $\left(\mathrm{m}^{2}\right)$ \\
acre & 0.4047 & hectare $(\mathrm{ha})$ \\
acre & 0.4047 & square hectometer $\left(\mathrm{hm}^{2}\right)$ \\
square foot $\left(\mathrm{ft}^{2}\right)$ & 0.004047 & square kilometer $\left(\mathrm{km}^{2}\right)$ \\
square foot $\left(\mathrm{ft}^{2}\right)$ & 929.0 & square centimeter $\left(\mathrm{cm}^{2}\right)$ \\
\hline & 0.09290 & square meter $\left(\mathrm{m}^{2}\right)$ \\
\hline ounce, fluid $(\mathrm{fl} . \mathrm{oz})$ & Volume & \\
gallon $(\mathrm{gal})$ & 0.02957 & liter $(\mathrm{L})$ \\
gallon $(\mathrm{gal})$ & 3.785 & liter $(\mathrm{L})$ \\
gallon (gal) & 0.003785 & cubic meter $\left(\mathrm{m}^{3}\right)$ \\
cubic foot $\left(\mathrm{ft}^{3}\right)$ & 3.785 & cubic decimeter $\left(\mathrm{dm}^{3}\right)$ \\
cubic foot $\left(\mathrm{ft}^{3}\right)$ & 28.32 & cubic decimeter $\left(\mathrm{dm}^{3}\right)$ \\
\hline & 0.02832 & cubic meter $\left(\mathrm{m}^{3}\right)$ \\
\hline foot per second $(\mathrm{ft} / \mathrm{s})$ & Flow rate & \\
cubic foot per second $\left(\mathrm{ft}^{3} / \mathrm{s}\right)$ & 0.3048 & meter per second $(\mathrm{m} / \mathrm{s})$ \\
inch per hour $(\mathrm{in} / \mathrm{h})$ & 0.02832 & cubic meter per second $\left(\mathrm{m}^{3} / \mathrm{s}\right)$ \\
\hline & 0.0254 & meter per hour $(\mathrm{m} / \mathrm{h})$ \\
\hline ounce, avoirdupois $(\mathrm{oz})$ & Mass & kilogram $(\mathrm{kg})$ \\
pound, avoirdupois $(\mathrm{lb})$ & 28.35 &
\end{tabular}

Temperature in degrees Celsius $\left({ }^{\circ} \mathrm{C}\right)$ may be converted to degrees Fahrenheit $\left({ }^{\circ} \mathrm{F}\right)$ as follows:

$$
{ }^{\circ} \mathrm{F}=\left(1.8 \times{ }^{\circ} \mathrm{C}\right)+32 .
$$

Temperature in degrees Fahrenheit $\left({ }^{\circ} \mathrm{F}\right)$ may be converted to degrees Celsius $\left({ }^{\circ} \mathrm{C}\right)$ as follows:

$$
{ }^{\circ} \mathrm{C}=\left({ }^{\circ} \mathrm{F}-32\right) / 1.8 .
$$




\section{Datum}

Vertical coordinate information is referenced to the North American Vertical Datum of 1988 (NAVD 88).

Horizontal coordinate information is referenced to the North American Datum of 1983 (NAD 83).

Altitude, as used in this report, refers to distance above the vertical datum.

\section{Supplemental Information}

Concentrations of chemical constituents in water are given in either milligrams per liter (mg/L) or micrograms per liter $(\mu \mathrm{g} / \mathrm{L})$. 



\title{
Hydraulic, Water-Quality, and Temperature Performance of Three Types of Permeable Pavement under High Sediment Loading Conditions
}

\author{
By William R. Selbig and Nicolas Buer
}

\section{Abstract}

Three permeable pavement surfaces—asphalt (PA), concrete (PC), and interlocking pavers (PIP) - were evaluated side-by-side to measure changes to the infiltrative capacity and water quality of stormwater runoff originating from a conventional asphalt parking lot in Madison, Wisconsin. During the 24-month monitoring period (2014-16), all three permeable pavements resulted in statistically significant reductions in the cumulative load of solids (total suspended solids and suspended sediment), total phosphorus, Escherichia coli (E. coli), and Enterococci. Most of the removal occurred through capture and retention in the void spaces of each permeable surface and aggregate base. The largest reduction in total suspended solids was for PC at 80 percent, followed by PIP and PA at 69 and 65 percent, respectively. Reductions (generally less than 50 percent) in total phosphorus also were observed, which might have been tempered by increases in the dissolved fraction observed in PIP and PA. Conversely, PC results indicated a slight reduction in dissolved phosphorus but failed to meet statistical significance. E. coli and Enterococci were reduced by about 80 percent for PC, almost twice the amount observed for PIP and PA.

Results for the PIP and PC surfaces initially indicated higher pollutant load reduction than results for the PA surface. The efficiency of PIP and PC surfaces capturing sediment, however, led to a decline in infiltration rates that resulted in more runoff flowing over, not through, the permeable surface. This result led to a decline in treatment until the permeable surface was partially restored through maintenance practices, to which PIP responded more dramatically than PC or PA. Conversely, the PA surface was capable of infiltrating most of the influent runoff volume during the monitoring period and, thus, continued to provide some level of treatment. The combined effect of underdrain and overflow drainage resulted in similar pollutant treatment for all three permeable surfaces.

Temperatures below each permeable surface generally followed changes in air temperature with a more gradual response observed in deeper layers. Therefore, permeable pavement may do little to mitigate heated runoff during summer. During winter, deeper layers remained above freezing even when air temperature was below freezing. Although temperatures were not high enough to melt snow or ice accumulated on the surface, temperatures below each permeable pavement did allow void spaces to remain open, which promoted infiltration of melted ice and snow as air temperatures rose above freezing. These open void spaces could potentially reduce the need for application of deicing agents in winter because melted snow and ice would infiltrate, thereby preventing refreezing of pooled water in what is known as the "black ice" effect.

\section{Introduction}

The adverse impacts of urbanization on the quantity and quality of stormwater runoff have been well documented (U.S. Environmental Protection Agency, 1983; Bannerman and others, 1993). Conversion of natural landscapes from pervious to impervious surfaces causes precipitation that previously would have infiltrated into soil to instead be collected into pipe and drainage networks allowing pollutants to migrate from source to stream resulting in what has been coined the "urban stream syndrome" (Walsh and others, 2005; Meyer and others, 2005; Wallace and others, 2008). Successful management of urban stormwater requires a diverse selection of tools to aid in the protection of water resources, aquatic habitat, and land from increased pollution and flood risks.

Traditional stormwater management has addressed hydrologic alterations caused by urbanization primarily with detention ponds as a means to reduce flood peaks and improve water quality. Although these practices have been successful in reducing episodic localized flooding, the practices are limited by a requirement of large tracts of land. Cities around the Nation lack limited open space for the construction of regional treatment structures, and although the possibility of retrofitting existing areas remains an option for environmental managers, costs may be prohibitive. For this reason, recent trends in 
urban stormwater management have shifted towards green infrastructure practices designed to reduce or delay peak flows of runoff by holding stormwater onsite, encouraging infiltration, and enhancing evapotranspiration. Permeable pavement is one type of green infrastructure practice that functions like traditional pavement for parking lots, sidewalks, and roadways but also allows for treatment and management of stormwater near its source (Drake and others, 2014a). Although permeable pavement has been in use for decades, quantifying the waterquantity and quality benefits of various forms of permeable pavement is ongoing. Some of the earliest investigations on the use of permeable pavements for urban runoff control were done by the U.S. Environmental Protection Agency in the 1970s (U.S. Environmental Protection Agency, 1983).

As technology evolves with better design, construction, and maintenance of stormwater control measures, environmental managers will need to develop and integrate strategies (such as permeable pavement) that promote a balance between existing and expanding urban areas and the environmental challenges they impose. The Wisconsin Department of Natural Resources promulgated a series of performance standards and prohibitions for nonpoint stormwater sources (Wisconsin Administrative Code, 2002). These standards are intended to be minimum benchmarks of performance necessary to achieve goals for water quantity and quality. A technical standard for permeable pavement, created in February 2016, describes required procedures and plans to design, install, and maintain permeable pavement in the State of Wisconsin in order to receive credits for reducing total suspended solids (TSS) and total phosphorus (Wisconsin Department of Natural Resources, 2016). Much of the language outlined in this guidance document was originally based on available literature; however, future versions will make use of data collected as part of this study.

Based on surface material, permeable pavements are typically grouped into either porous asphalt (PA), pervious concrete (PC), or permeable interlocking pavers (PIP). Despite variations in construction materials and binding agents, each type presents a rigid surface designed to reduce runoff by allowing infiltration through the surface and into a permeable base (Eisenberg and others, 2015; Bean and others, 2007). In most cases, the permeable base is built over underlying soils to allow for exfiltration of runoff. However, in some situations, such as locations with shallow groundwater or bedrock, an underdrain resting on top of an impermeable liner may be placed under the aggregate base.

Because of limitations in structural stability, permeable pavements are primarily used in low-volume traffic zones such as walkways, parking lots, driveways, and courtyards. The designers of each system must consider site-specific characteristics that include not only structural factors but also stormwater management goals (Eisenberg and others, 2015). In some cases, stormwater volume reduction may be the primary concern. Roseen and others (2012) determined that the use of PA in parking lots reduced peak stormflow by up to 90 percent. Use of PIP in low impact developments has increased runoff lag time and duration and decreased stormwater volume and peak flow compared to impermeable surfaces (Fassman and Blackbourn, 2010; Gilbert and Clausen, 2006). Exfiltration increased base flow in urban streams indicating greater groundwater connectivity and potential water cycle rejuvenation with the use of unlined permeable pavement systems (Roseen and others, 2012; Sansalone and others, 2012; Roseen and others, 2010).

Much of the volume reduction capabilities of permeable pavements can be attributed to the size of the contributing drainage area. A study of four different permeable pavements in Washington that received only direct precipitation determined that virtually all rainwater had infiltrated through the permeable surfaces with almost no surface runoff (Brattebo and Booth, 2003). Conversely, 16 and 32 percent reductions in stormwater volume were measured from two permeable pavement systems receiving runoff from catchments that were 7.2 and 2.2 times larger than the receiving permeable pavement area, respectively (Winston and others, 2016b). Because the hydraulic capacity of permeable pavement can vary depending on many site-specific characteristics such as age and maintenance practices, the contributing drainage area is often based on professional judgement; however, many guidance documents suggest the total drainage area be no greater than 2.5 times the permeable pavement surface area (Eisenberg and others, 2015). Additional research documenting site conditions with associated hydraulic and water-quality performance of permeable pavement could improve suggested drainage limits.

Permeable pavement also has been determined to change the quality of stormwater runoff. Several studies report high sediment removal rates (Roseen and others, 2012; Roseen and others, 2010; Barrett, 2008) and removal efficiency can vary in relation to particle size (Brown and others, 2009). Similarly, positive removal efficiencies of hydrocarbons, total metals, and total phosphorus have also been measured because of their strong association with particulate matter (Roseen and others, 2012; Gilbert and Clausen, 2006; Balades and others, 1995). The primary mechanism behind removal of sediment and sediment-associated pollutants is filtration and sedimentation, with the majority of sediment accumulation occurring within the top few inches of the pavement structure (Brown and others, 2009; Lucke and Beecham, 2011; Winston and others, 2016a). Despite the high efficiency in sediment removal, many studies report little to no treatment of dissolved-phase pollutants, particularly chloride, phosphorus, and nitrate; and, in some cases, have shown exports of these pollutants from permeable pavements (Drake and others, 2014a; Brown and Borst, 2015b; Winston and others, 2016b).

When the ability to infiltrate runoff diminishes as more sediment is captured and retained, regular maintenance in the form of cleaning becomes increasingly important to maximize performance and extend the life of permeable pavement. The American Society of Civil Engineers recommend vacuum sweeping for prevention and rehabilitation of permeable surfaces (Eisenberg and others, 2015). The maintenance practice of vacuum sweeping was determined to be variable, 
but somewhat effective, at improving the infiltrative capacity of severely clogged pavements (Chopra and others, 2010). Pressure washing, especially when combined with vacuum sweeping, was determined to result in greater rejuvenation of pervious concrete; however, vacuuming sweeping extracts particles closer to the surface, whereas pressure washing pushes the particles deeper inside the surface (Chopra and others, 2010). Deeper penetration of fine particles (silts and clays) accumulating near the bottom of PC were documented by Mata (2008). Milling away the top 1 inch of permeable asphalt was determined to be more effective than vacuum sweeping because milling removes deeper penetrating sediment (Winston and others, 2016a).

Additional information is needed to fully understand the physical, chemical, and biological processes of various permeable pavement systems and their impact to water quality. More data are also needed on the indirect environmental benefits of permeable pavement. For example, Roseen and others (2014) documented that the application of deicing salt on permeable pavements could potentially be reduced by 77 percent compared to impermeable asphalt while maintaining equivalent surface traction. The reduced need for deicers could have a profound environmental benefit in northern climates.

For these reasons, the U.S. Geological Survey led a study to evaluate the hydraulic and water-quality performance of three types of permeable pavement. A permeable pavement research facility was built to facilitate volumetric and water-quality measurements of stormwater runoff originating from a conventional asphalt parking lot that was equally distributed into one of three permeable pavements-PA, PC, and PIP. Data were collected from August 25, 2014 through September 7, 2016. This study supports an ongoing effort to identify existing and new methods to mitigate urban nonpoint stormwater as well as provide high-resolution data critical to understanding the urban component of the hydrologic cycle.

\section{Site Description}

In the summer of 2014, a permeable pavement test site was constructed adjacent to a public parking lot on the northeast side of Madison, Wisconsin, (fig. 1). The curbed asphalt lot provides parking for city of Madison employees as well as users of a nearby dog park. Asphalt berms were used to create an impermeable surface area ( 0.32 acre) with approximately 45 parking spaces and associated driving lanes that naturally drain towards the test site. The parking lot was approximately 25 years old at the time of the study and in poor condition. Maintenance of the parking lot was limited to a one-time repair of large potholes in May 2015. During the winter, snow and ice were removed from the parking lot by use of plows and a mixture of sand and salt when needed. Vehicles were restricted to the parking lot only and prohibited from accessing the permeable surfaces.
The test site was split into three individual plots designed to evaluate variations of permeable pavement-PA, PC, and PIP. The permeable surfaces were selected based on the overall prevalence of use by consumers and interest from industry representatives on the performance of their product. A conceptual diagram profiling each of the test plots is shown in figure 2. Each 500-square foot plot had a depth of approximately 21 inches with an impermeable membrane lining the sloped base (approximately 2 percent) to prevent exfiltration into underlying soils. A 6-inch diameter polyvinyl chloride (PVC) underdrain was placed upon the impermeable membrane in each cell to collect and route filtered stormwater towards a monitoring vault. The placement of the underdrain was chosen to minimize internal water storage thereby limiting removal of solids through settling. As such, measurements of hydraulic and water-quality performance are representative of only the combined effect for the permeable surface and aggregate base.

Overlying the underdrain was a layer of washed stone aggregate that was 15-18 inches. Based on American Society of Testing and Materials (ASTM) classification standards (American Society of Testing and Materials, 2002), the aggregate supporting PA and PC was a compacted number (no.) 57 stone (0.1-1.5 inches nominal diameter), whereas PIP used a gradation of compacted aggregate starting with a no. $2(0.75-$ 3.0 inches nominal diameter), followed by no. 57 , and finally a no. 9 (less than $0.1-0.2$ inch nominal diameter) stone immediately beneath the paving course (fig. 2). The no. 9 stone was also used to fill the 0.25 -inch joints between the PIP at the surface. The thickness of each permeable surface varied from 3.0 inches for PA (approximately 20 percent porosity), 3.13 inches for PIP (approximately 5-10 percent porosity), and 6.0 inches for PC (approximately 20 percent porosity). Concrete walls were placed around the perimeter of each plot (subgrade) to prevent lateral exfiltration into underlying soils or between test plots. Similarly, rubberized berms were used at the surface to prevent cross-contamination of surface flow between test plots above grade. Runoff that may have cascaded across each permeable surface as overflow was collected via surface grate and routed by PVC pipe towards the monitoring vault.

The drainage ratio, defined as the ratio of impervious run-on area to permeable pavement surface area, is specified by the Wisconsin Department of Natural Resources as a value less than or equal to three for roads and five for other impervious surfaces such as parking lots, rooftops, and driveways (Wisconsin Department of Natural Resources, 2016). These guidelines were established to minimize the surface clogging of permeable pavement; to extend the ability of permeable pavement to infiltrate runoff throughout several years. Other guidance documents adopt a more conservative approach by recommending a contributing drainage area that is typically less than twice the surface area of the permeable pavement (Minnesota Pollution Control Agency, 2017). The American Society of Civil Engineers recommends the ratio of drainage area to receiving permeable pavement area, in general, be 2:5 (Eisenberg and others, 2015). Exceptions are allowed 
$\boldsymbol{A}$

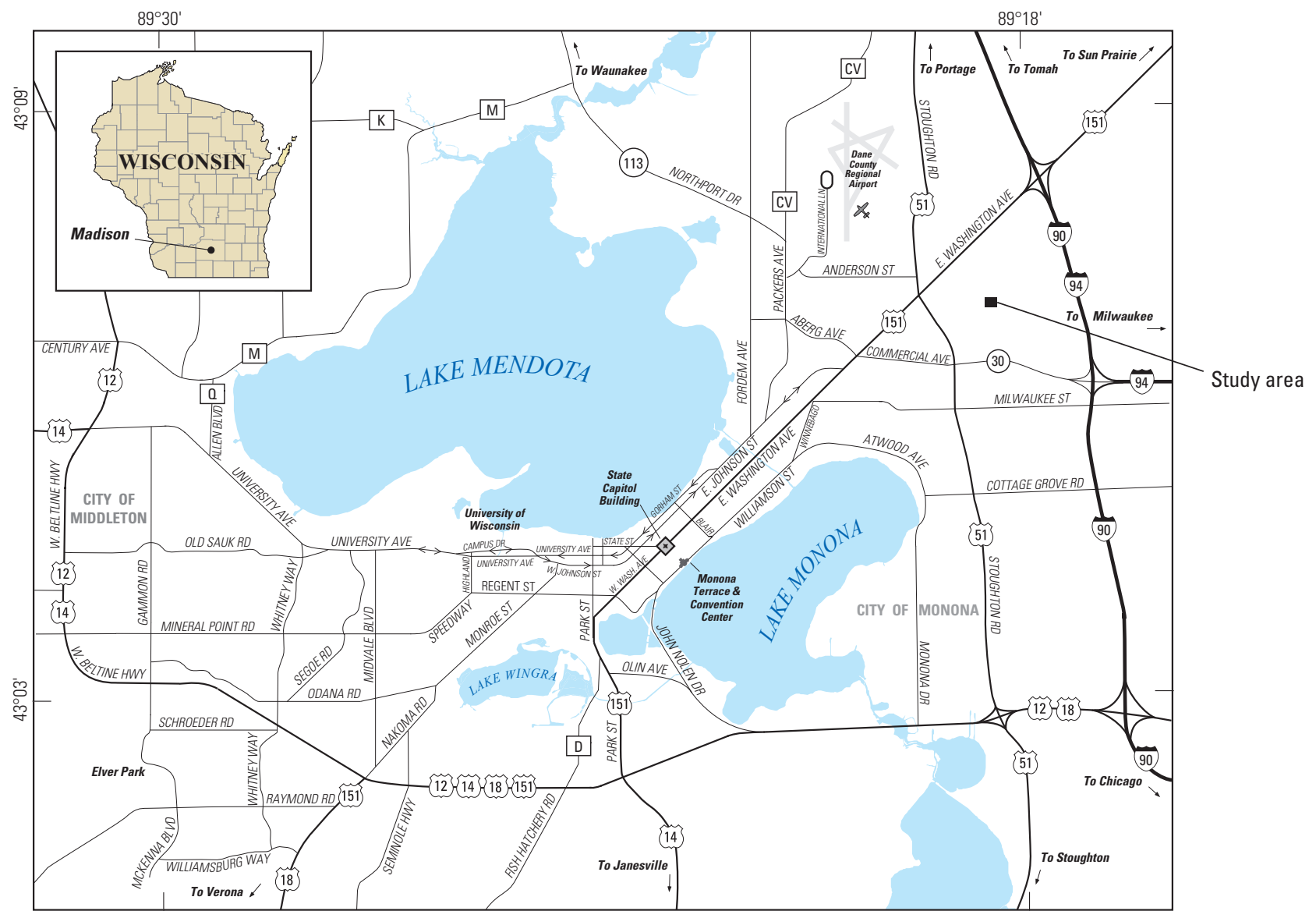

Base map from U.S. Geological Survey digital data

2 MILES

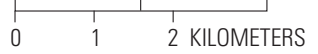

B

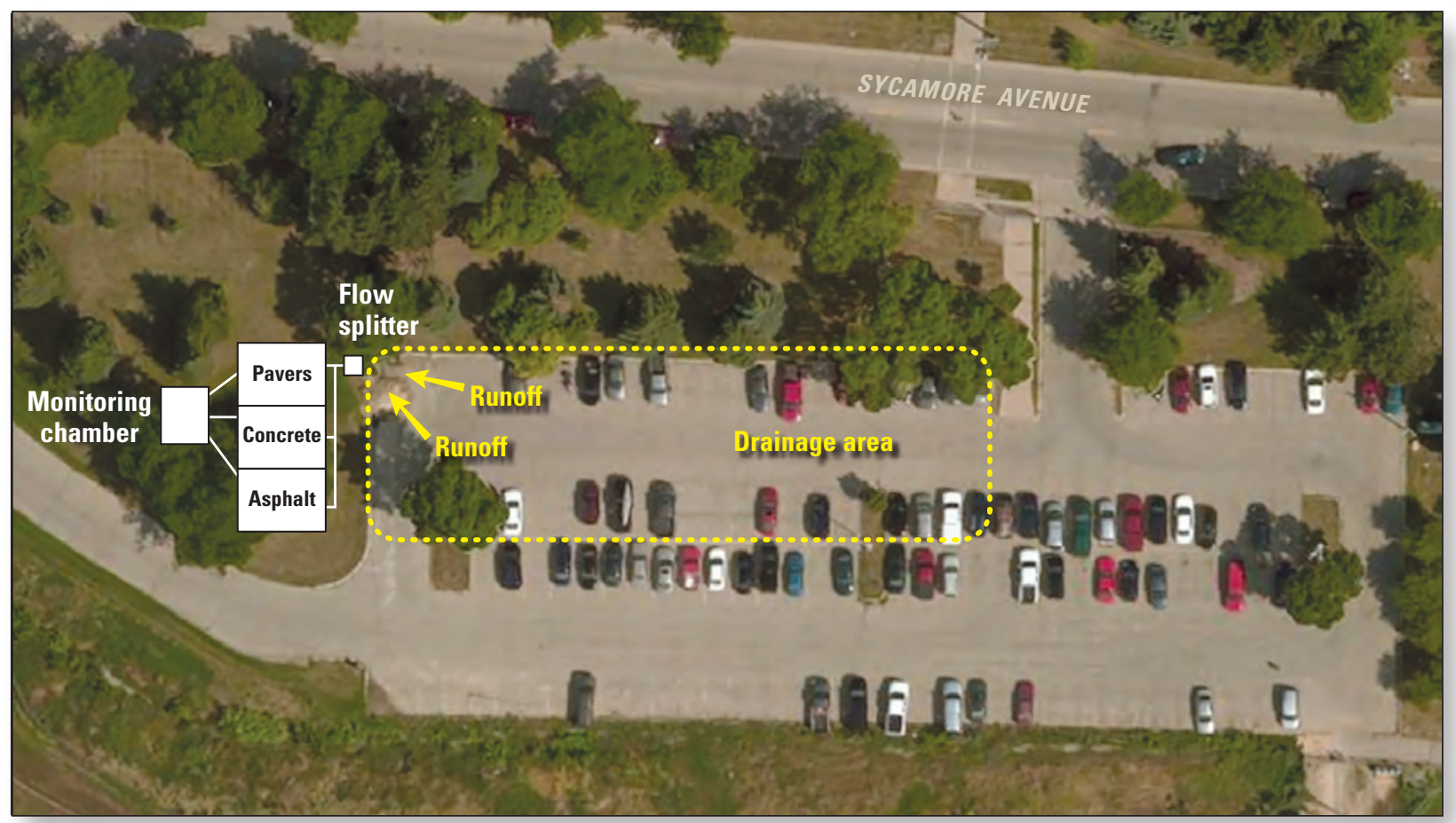

Schematic not drawn to scale.

Figure 1. Map and corresponding aerial photograph showing $A$, location of permeable pavement research facility in Madison, Wisconsin, and $B$, schematic of drainage area and orientation of permeable pavements. 


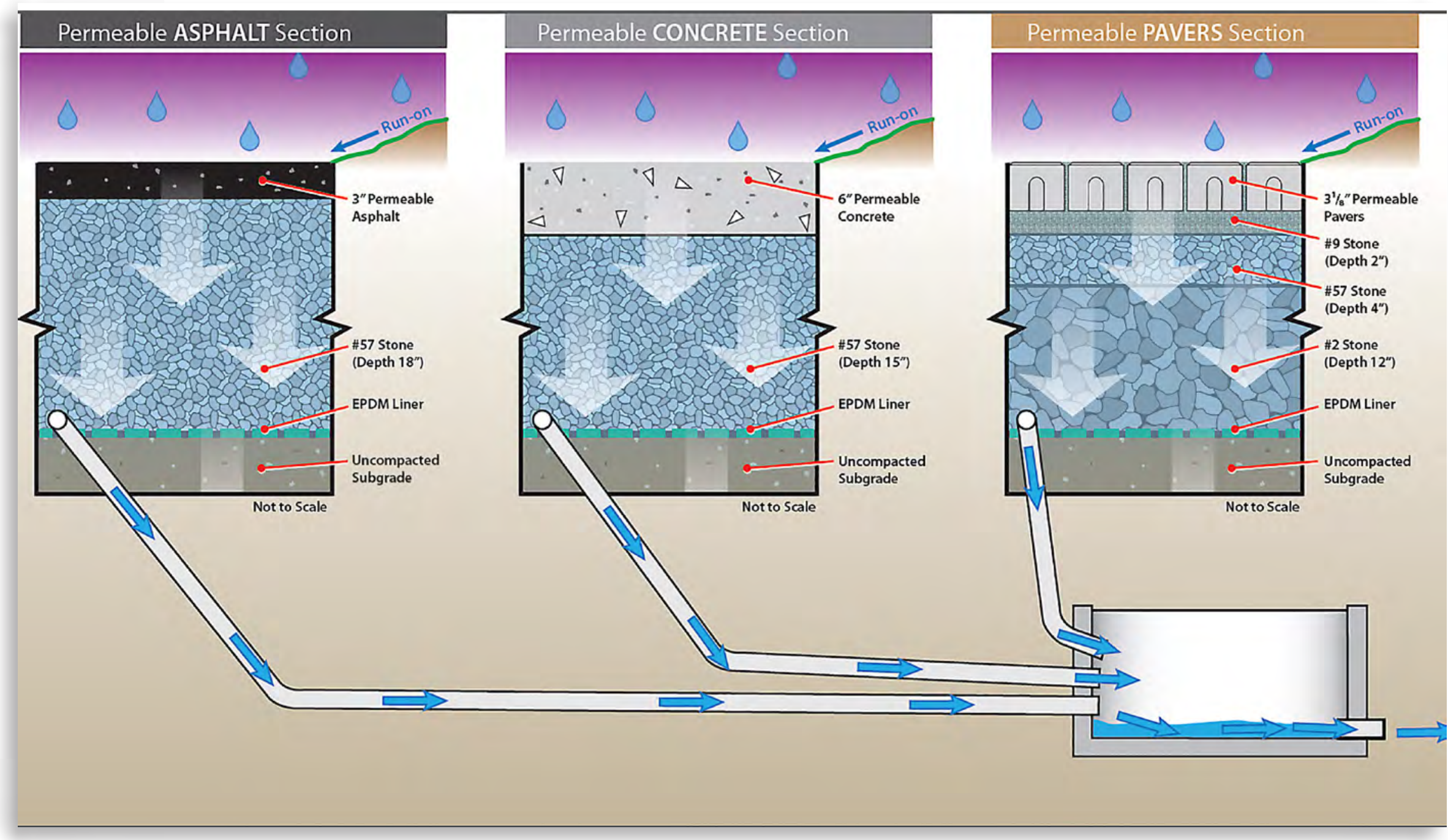

Figure 2. Conceptual diagram showing cross-sectional profile of porous asphalt, pervious concrete, and permeable interlocking pavers test surfaces and aggregate base. Blue arrows indicate flow of infiltrated runoff from the underdrain towards the monitoring chamber. (Courtesy of County Materials Corporation). 
if specific site conditions exist, such as if the permeable pavement is receiving runoff from roofs or if the pavement undergoes some form of pretreatment to remove sediment. This study stressed the permeable surfaces by increasing the drainage ratio beyond conventional guidelines as a way to accelerate clogging. By doing so, permeable pavement response to high sediment and hydraulic loading rates can be measured in a shorter period. To create a well-defined drainage boundary, impermeable asphalt berms were placed within the existing parking lot, thereby limiting contributions of runoff from undefined sources. The resulting drainage ratio for each permeable surface at the Madison test site was 9.3:1, almost twice the maximum amount currently allowed by the Wisconsin Department of Natural Resources (2016).

Maintenance of the test site was minimal once construction was complete. Approximately 1 month after construction, each test plot was flushed with a large volume of clean water from a nearby fire hydrant. This flushing was done to minimize the amount of residual dust that may have accumulated on the aggregate base during the construction process. The lawn was mowed by city personnel periodically throughout the summer, with vegetative debris discharged away from the test site. In the fall, leaf litter from the few trees surrounding the site, was allowed to accumulate on the test cells. During winter, snow accumulation that exceeded 2 inches was removed from the permeable test surfaces by a hand-operated snow thrower. Sand or salt was not applied on the permeable surfaces.

\section{Methods of Data Collection}

The monitoring period was from August 21, 2014, through September 6, 2016. Monitoring stations measured discharge and collected water-quality samples from seven locations at the test site - untreated runoff from the parking lot, runoff that filtered through each permeable surface, and runoff that cascaded across each permeable surface as overflow. Hydrologic data were continuously recorded at 1-minute increments during periods of runoff and hourly during interevent periods.

\section{Flow Measurement}

Stormwater runoff from the parking lot was measured by means of a 60 -degree trapezoidal flume with an attached stilling well (fig. $3 A$ ). A submersible pressure transducer, calibrated to the nearest 0.01 foot, measured the changing water level in the flume that was then used to compute instantaneous discharge by use of standard flume equations. Water passing through the flume emptied into a concrete structure with three 6-inch PVC pipes, each having the same invert elevation. The concrete structure was designed to minimize opportunities for sediment to settle out of suspension; however, runoff from the parking lot entered a shallow sump (approximately 4-inch depth) before passing through the PVC pipes. Based on visual observation, sediment did not accumulate in the sump after runoff events. The concrete structure and pipes served as a flow splitter designed to split the volume of runoff from the parking lot into three equal portions to the PA, PC, and PIP test plots (fig. 3A). This configuration is unique in that it allows for the direct measurement of the quantity and quality of runoff delivered from the parking lot to each permeable surface. Other studies (Winston and others, 2016b; Brown and Borst, 2015b; Drake and others, 2014a; Brattebo and Booth, 2003) simply measured the quantity and quality of runoff from a section of asphalt parking lot near, but not directly upstream of, the permeable test surface. Resulting runoff volumes and concentrations were then assumed the same as those delivered to the test surface. This "assessment by proxy" method could increase uncertainty when calculating pollutant removal efficiencies.

Once delivered to the test plot, runoff was spread across a serrated weir plate for even distribution of water across the permeable surface to prevent short-circuiting (fig. 3B). Stormwater would either filter through the permeable surface or bypass as overflow where stormwater was collected and conveyed separately to a concrete monitoring vault by use of 6-inch PVC pipes. Each pipe emptied into a fiberglass box equipped with a 6-inch H-flume for measurement of overflow or 8-inch $\mathrm{H}$-flume for measurement of underdrain discharge (fig. 3C). A submersible pressure transducer, calibrated to the nearest 0.01 foot, measured the changing water level in the $\mathrm{H}$-flumes that were then used to compute instantaneous discharge by use of standard flume equations.

\section{Precipitation}

Continuous precipitation data were collected by use of a tipping-bucket rain gage calibrated to 0.01 inch per tip. The rain gage was approximately 25 feet north of the permeable pavement research facility in an area free of overhead tree canopy or other larger structures. The rain gage was not designed to measure snowfall; however, some runoff events were during the winter when precipitation was in the form of rain instead of snow. Because of the roughness of the parking lot, runoff did not typically occur until rainfall exceeded $0.1 \mathrm{inch}$.

\section{Water Temperature}

Continuous water temperature was measured with an insulated thermocouple wire during periods of runoff. Thermocouples were placed at the flume approach and exit for runoff influent and underdrain effluent, respectively. The temperature of runoff that bypassed as overflow was not measured. Additionally, a matrix of 27 thermocouples was installed below each permeable surface to measure both ambient air and water temperature as runoff percolated across and through each system. The thermocouples were in a three by three matrix with measurements made at approximately 0,6 , and 12 inches below the permeable layer into the aggregate base (fig. 4). Additional thermocouples were used to measure the surface temperature of each permeable system. 


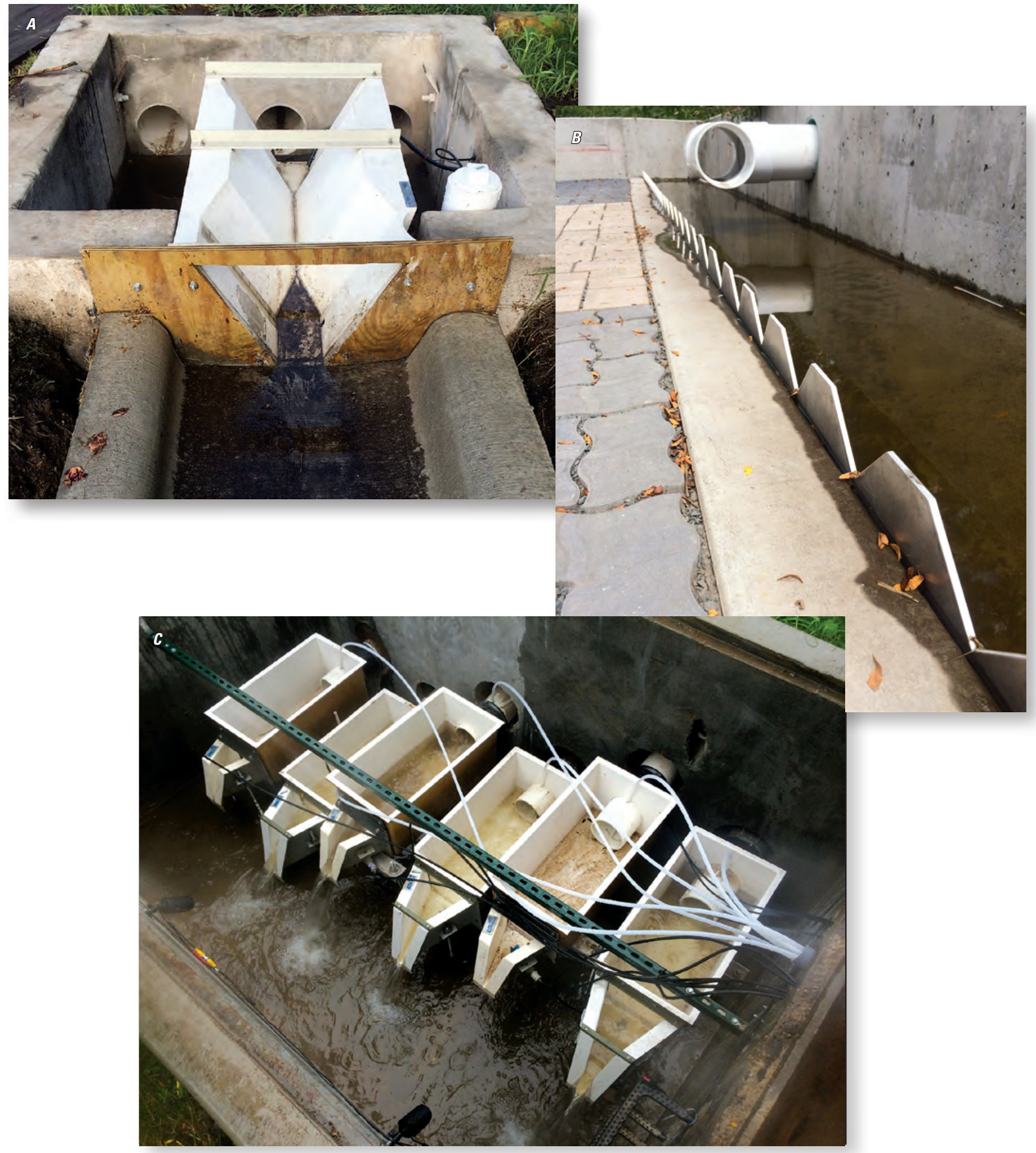

Figure 3. Hydraulic structures used to $A$, measure and distribute the flow of runoff from the parking lot; $B$, uniformly spread runoff across the test surface; and $C$, measure runoff that either passes through the underdrain of each permeable surface or bypasses as overflow. 


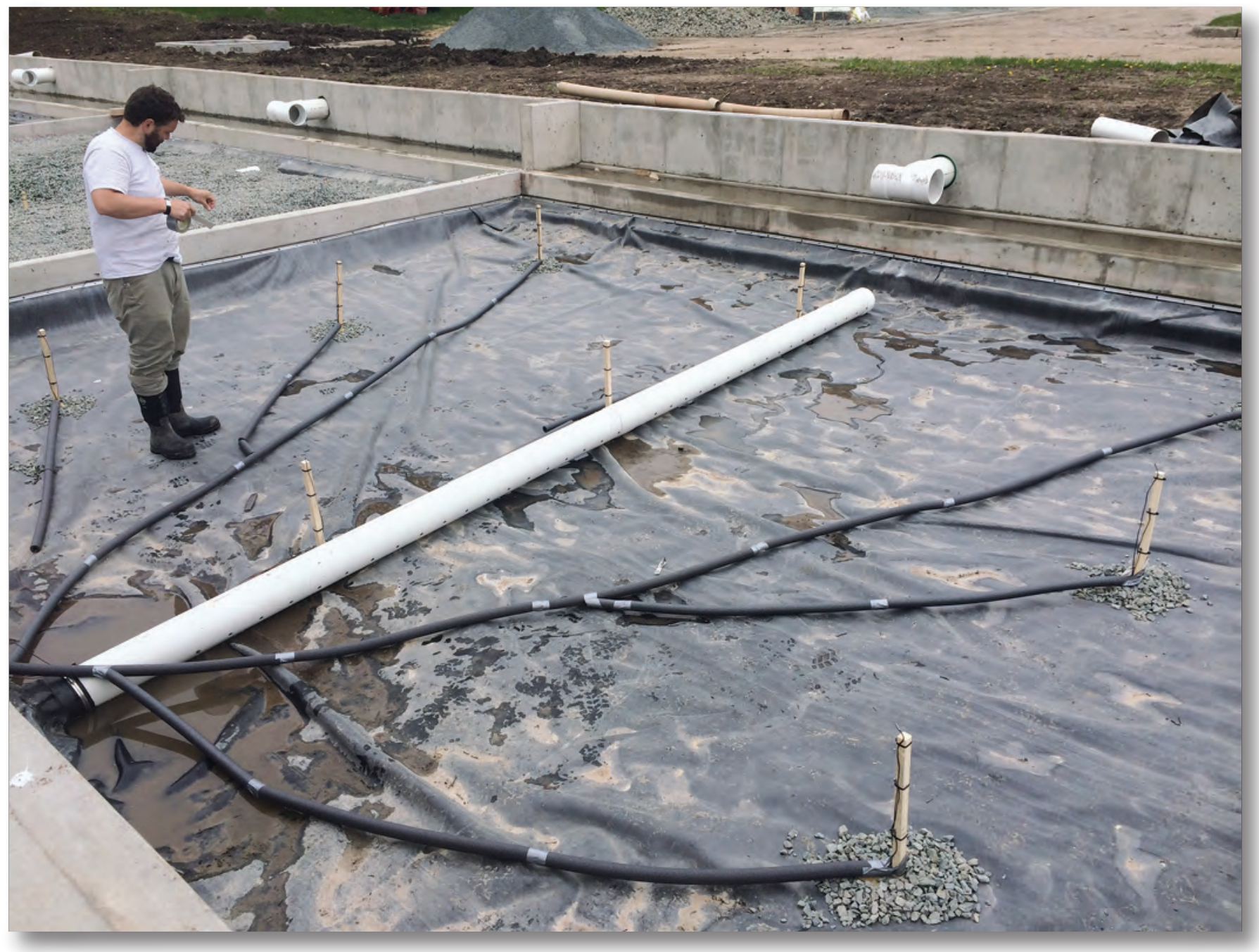

Figure 4. A network of temperature sensors placed in the porous asphalt test plot prior to installation of the aggregate base and asphalt surface. Attached to each wooden dowel placed in the three by three matrix were sensors spaced at about 0 (top), 6 (middle), and 12 (bottom) inches below the permeable surface. The pervious concrete and permeable interlocking pavers test plots had a similar configuration. 


\section{Runoff Sample Collection and Analyses}

The influent and effluent monitoring stations were equipped with refrigerated, automated samplers. Each sampler had an orifice diameter of approximately 0.375 inch and withdrawal velocity of approximately 3.0 feet per second. The sample intake for the parking lot influent was at the exit of the trapezoidal flume, whereas the intake for the underdrains and overflows were inside PVC pipes upslope of the $\mathrm{H}$-flume approach section (fig. 3C). Sample collection was activated by a rise in water level in the flumes during a precipitation or snowmelt event, or both. Once a water-level threshold was exceeded, typically 0.07 foot above the point of zero flow, the volume of water passing the station was measured and accumulated at 1-minute increments until a volumetric threshold was reached. At that point, a discrete water sample was collected, and the volumetric counter was reset. This process was repeated until the water level receded below the threshold. All flow-weighted discrete samples collected throughout the duration of an event hydrograph were combined into a single, composite sample, resulting in an event mean concentration (EMC) that represented a minimum of 80 percent of the storm hydrograph. Water-quality samples were collected within 24 hours after runoff cessation. A Teflon churn splitter was used to composite and split samples into smaller plastic sample containers to be delivered to the analytical laboratory. A portion of the composite sample was processed through a 0.45 micrometer filter for analyses of dissolved constituents. All processed samples were kept in a refrigerator at 4 degrees Celsius $\left({ }^{\circ} \mathrm{C}\right)$ until delivered to the analytical laboratory, usually within 48 hours after runoff cessation. Samples were analyzed at the Wisconsin State Laboratory of Hygiene (WSLH), in Madison, Wis., for determination of constituent concentrations (table 1).

\section{Measurement of Infiltration Rates}

Infiltration rates were measured using a modified version of the ASTM standard test method C1701/1701M (American Society of Testing and Materials, 2009). Although designed for PC, the method was applied to all three permeable surfaces in this study. This method measures the time required to infiltrate a known volume of water through a ring of known area sealed to the permeable surface. The device used to measure infiltration rates of each permeable surface is shown in figure 5. The ring consisted of a 12-inch diameter PVC pipe cut to 3.5 inches. The ring was sealed to the pavement by use of rolled coils of pottery clay. Water in the ring maintained a constant head of 0.4-0.6 inch by use of an automatic water feeder consisting of a 6-inch diameter PVC pipe with a tightfitting cap capable of holding 1 gallon of water. A total of 12 evenly spaced 0.25 -inch slits were cut into the cap at a depth of 0.6 inch. When inverted, the automatic water feeder filled the area inside the test ring with water to the height of the slits $(0.6$ inch). Once water in the ring reached this height, a vacuum inside the automatic water feeder prevented more water from escaping until the water level in the ring dropped again. This auto-regulation through water level manipulation, a commonly used principle in water tanks for livestock, was able to produce the constant head needed for this test.

Table 1. Constituents analyzed in influent and effluent runoff at the permeable pavement test site, Madison, Wisconsin.

[MDL, minimum detection limit; mg/L, milligram per liter; SM, Standard Methods (Eaton and others, 1998); ASTM, American Society of Testing and Materials (2013); EPA, U.S. Environmental Protection Agency (U.S. Environmental Protection Agency, 1993, 2003); cfu/100 mL, colony-forming units per 100 milliliters]

\begin{tabular}{llll}
\hline \multicolumn{1}{c}{ Constituent } & Units & MDL & \multicolumn{1}{c}{ Method } \\
\hline Total suspended solids (TSS) & $\mathrm{mg} / \mathrm{L}$ & 2.0 & SM 2540D \\
Suspended sediment concentration (SSC) & $\mathrm{mg} / \mathrm{L}$ & 2.0 & ASTM D3977-97B \\
Total phosphorus (TP) & $\mathrm{mg} / \mathrm{L}$ & 0.005 & EPA 365.1 \\
Dissolved phosphorus (DP) & $\mathrm{mg} / \mathrm{L}$ & 0.005 & EPA 365.1 \\
Chloride (Cl) & $\mathrm{mg} / \mathrm{L}$ & 1.0 & SM 4500-CL-E \\
Escherichia coli $($ E. coli) & $\mathrm{cfu} / 100 \mathrm{~mL}$ & 100 & SM 9223 BMPN \\
Enterococci & $\mathrm{cfu} / 100 \mathrm{~mL}$ & 100 & EPA 2003 \\
\hline
\end{tabular}




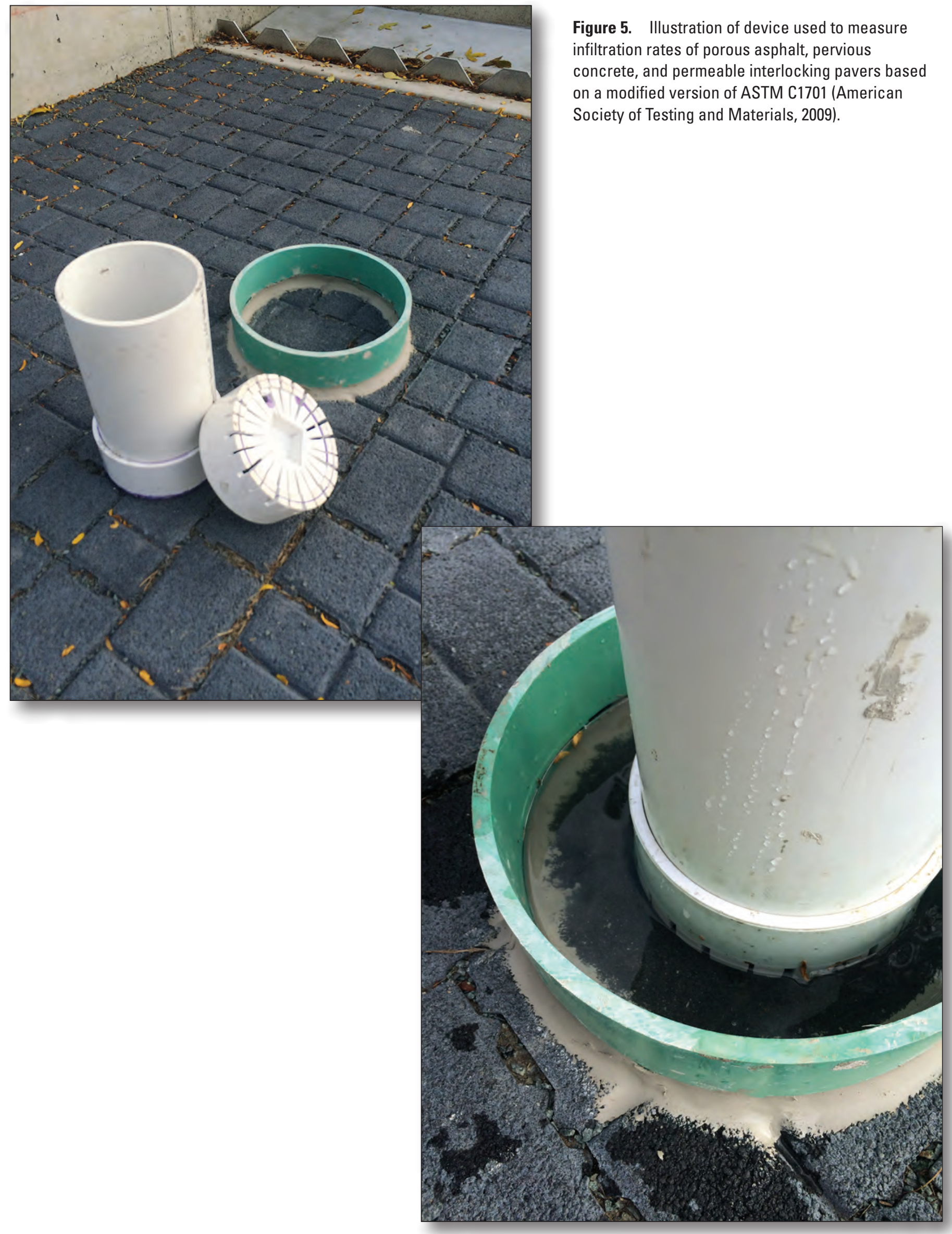


Each infiltration test was initially done using 1 gallon of water. If complete infiltration of 1 gallon occurred within 30 seconds, a second test was done using 5 gallons of water to provide a more accurate assessment of the infiltration rate. Infiltration tests were done at each permeable surface approximately once per month except in the winter (typically December through March). Each test location consisted of a three by three matrix spaced evenly across the 25 - by 20 -foot permeable pavement plot. Each monthly test was done in the exact same manner and in the exact same location. Infiltration rates were calculated using equation 1 .

$$
I=\frac{K M}{\left(D^{2 *} t\right)}
$$

where

$\begin{array}{cl}I & \text { is the infiltration rate, in inches per hour; } \\ K & \text { is a conversion factor equal to } 126,870 ; \\ M & \text { is the mass of infiltrated water, in pounds; } \\ D & \text { is the inside diameter of the infiltration ring, } \\ & \text { in inches; and } \\ t & \text { is the infiltration time, in seconds. }\end{array}$

\section{Data Analyses}

The performance of PA, PC, and PIP was based on a calculated removal efficiency. The calculated removal efficiency was based on comparisons of influent and effluent pollutant load for sampled events. Summary statistics for censored concentration data (below detection limits) were estimated by use of the Kaplan-Meier method (Helsel, 2005). Storm event loads at each monitoring location were computed by multiplying the EMC by event runoff volumes. For censored concentrations, a value of one-half the EMC was used to compute an event load. The EMC of pollutants influent to each permeable surface were assumed to be the same; however, load calculations applied a flow-proportional adjustment based on the ratio of underdrain and overflow effluent volume measured at each test plot to the total influent volume from the parking lot (eq. 2). Cumulative volumetric losses caused by evaporation in permeable pavement during a 2-year period were estimated to be about 5 percent of cumulative rainfall (Brown and Borst, 2015a). However, volumetric losses caused by evaporation and storage are not relevant when determining pollutant load.

$$
L_{\text {adj }}=L_{\mathrm{i}} *[\mathrm{Vu} / \mathrm{o} / \mathrm{Vi}]
$$

where
$L_{\text {adj }} \quad$ is the adjusted load delivered to each permeable surface, in grams;
$\mathrm{Li} \quad$ is the load measured from the parking lot, in grams;
$\mathrm{Vu} / \mathrm{o} \quad$ is the volume measured at the underdrain or overflow, in cubic feet; and
$V i$ is the volume measured from the parking lot, in cubic feet.

Load data were first tested for normality by use of the Shapiro-Wilk test (Helsel and Hirsch, 2002). Generally, the data followed a log-normal distribution in which the statistically significant differences between paired influent and effluent loads were evaluated by use of paired t-tests (Helsel and Hirsch, 2002). All other load data were evaluated by use of the nonparametric Wilcoxon signed-rank test (Helsel and Hirsch, 2002). All statistical tests were first done using an upper-tailed test in which the null hypothesis assumed that the influent and effluent loads were not different. If the null was rejected, tests were repeated to determine if the influent load was statistically greater or less than the effluent load. All tests used a 95 percent confidence level $(\alpha=0.05)$ unless otherwise noted.

\section{Quality Assurance and Quality Control}

Field and sample-processing equipment blanks were collected at all sample collection points, with the exception of the PA overflow, to evaluate the integrity of the water-quality sampling process, identify if sample contamination existed and, if so, to identify possible sources. Blank samples were obtained by drawing deionized water through the suction line and sampler into a glass collection bottle. The sample line and automatic sampler were not cleaned before obtaining blank samples. Collected blank water was then split through a Teflon churn splitter into plastic laboratory-prepared sample bottles. Samples were placed on ice and delivered to the WSLH for analysis. Deionized blank water also was used to isolate individual elements of the sampling process from source to delivery. These samples were not delivered to the WSLH unless erroneous concentrations were detected in the original blank sample. Blank-sample results are listed in table 2. A replicate sample was also collected to evaluate the inherent variability in sampling analyses and methods.

The blank samples were analyzed and results determined the bias and variability were within acceptable limits for dissolved phosphorus, chloride, TSS, suspended sediment, and Enterococci. Of the blank samples, three had concentrations above the detection limit for total phosphorus and two samples had concentrations above the detection limit for E. coli. Because the concentrations of total phosphorus and E. coli were much lower than those measured in water-quality samples, both constituents were considered insignificant to the overall integrity of the water-quality sampling process.

A replicate sample was submitted to verify reproducibility in the sample acquisition and splitting process as well as analytical methods conducted in the laboratory. The replicate sample was checked for precision based on an absolute relative percent difference (RPD). Results from the replicate samples are listed in table 2 . The majority of RPD values for replicate samples collected at the PIP underdrain were all within an acceptable range of error (less than 25 percent). Enterococci and E. coli were not replicated well in the laboratory with RPDs exceeding 65 percent. Some of the error could be due to timing of the analysis. For E. coli and Enterococci, 
Table 2. Quality assurance sample results from the permeable pavement research facility in Madison, Wisconsin.

[DP, dissolved phosphorus; TP, total phosphorus; TSS, total suspended solids; SSC, suspended sediment concentration; Cl, chloride; E. coli, Escherichia coli; $<$, less than; PA, porous asphalt; PC, pervious concrete; PIP, permeable interlocking pavers; RPD, relative percent difference; NA, not applicable; values are in grams except for $E$. coli and enterococci, which are in colonies]

\begin{tabular}{lcccccccc}
\hline \multicolumn{1}{c}{ Sample identification } & $\begin{array}{c}\text { Date } \\
\text { (month/day/ } \\
\text { year) }\end{array}$ & DP & TP & TSS & SSC & CI & E. coli & Enterococci \\
\hline & \multicolumn{7}{c}{ Blanks } \\
\hline Influent & $06 / 04 / 2015$ & $<0.005$ & 0.006 & $<2.0$ & $<2.0$ & $<1.00$ & $<1$ & $<1$ \\
PA underdrain & $06 / 04 / 2015$ & $<0.005$ & $<0.005$ & $<3.3$ & $<2.0$ & $<1.00$ & $<1$ & $<1$ \\
PC underdrain & $06 / 04 / 2015$ & $<0.005$ & $<0.005$ & $<2.0$ & $<2.0$ & $<1.00$ & $<1$ & $<1$ \\
PC overflow & $06 / 04 / 2015$ & $<0.005$ & $<0.005$ & $<2.0$ & $<2.0$ & $<1.00$ & $<1$ & $<1$ \\
PIP underdrain & $06 / 04 / 2015$ & $<0.005$ & 0.006 & $<2.0$ & $<2.0$ & $<1.00$ & 1 & $<1$ \\
PIP overflow & $06 / 04 / 2015$ & $<0.005$ & 0.006 & $<2.0$ & $<2.0$ & $<1.00$ & 6 & $<1$ \\
\hline & & \multicolumn{7}{c}{ Replicates } \\
\hline PIP underdrain (original) & $04 / 07 / 2015$ & 0.0503 & 0.266 & 209 & 168 & 11.8 & 6 & 3 \\
PIP underdrain (replicate) & $04 / 07 / 2015$ & 0.0505 & 0.265 & 165 & 169 & 11.8 & 12 & 21 \\
RPD (in percent) & NA & 0 & 0 & 24 & 1 & 0 & 67 & 150 \\
\hline
\end{tabular}

the concentration in the replicate sample was greater than in the original sample, indicating bacterial growth. Given the low concentrations of both the original and replicate samples compared to concentrations measured in water-quality samples, changes because of analytical bias were considered insignificant to the overall integrity of the water-quality sampling process.

\section{Comparison of Hydraulic Performance}

During the 24-month monitoring period, 98 runoff events were measured at the permeable pavement test site. Although most of events were a result of precipitation greater than 0.1 -inch, some runoff events were the result of snowmelt or a combination of rain and snowmelt.

\section{Precipitation}

The climate in Madison is typical of interior North America, with daily mean air temperatures ranging from $28{ }^{\circ} \mathrm{C}$ in July to $-12^{\circ} \mathrm{C}$ in January (National Oceanic and Atmospheric Administration, 2016). Based on the 30-year normal (1980-2010), annual precipitation for this area is 36 inches of which 13 percent occurs in winter (December-February), 26 percent in spring (March-May), 47 percent in summer (June-September), and 14 percent in fall (OctoberNovember). Departures from normal monthly precipitation depth during the monitored period are shown in figure 6. Winter months from December through February were excluded because the precipitation gage was not equipped to measure the water equivalency of snow. Monthly precipitation generally was below normal during the 2014 monitoring year. Monthly precipitation generally was within 1 inch of normal in 2015 except September and November, which were above normal. Monthly precipitation was similar in 2016, with August and September recording more than 6 inches.

Previous studies indicate that particulates in stormwater runoff could be related to seasonal patterns in precipitation characteristics in what is described as a "first flush" effect (Schiff and others, 2016; Borris and others, 2013). Winston and others (2016a) also highlighted the effect of seasonal precipitation characteristics by determining that the water-quality performance of permeable pavements could be conservative because collection of samples tends to represent only storms of high depth and intensity, whereas smaller storms are likely to be completely captured and retained in the underlying aggregate. Summary statistics for all monitored and sampled precipitation events with depths greater than 0.1 inch are listed in table 3. A minimum threshold of $0.1 \mathrm{inch}$ was selected because it represents the depth required to generate measurable runoff from the parking lot. Precipitation characteristics for all monitored and sampled events are in Selbig (2018). Except for December through February, each month had at least one runoff event that was sampled for water quality; with August having the most $(n=11)$ and June and November 


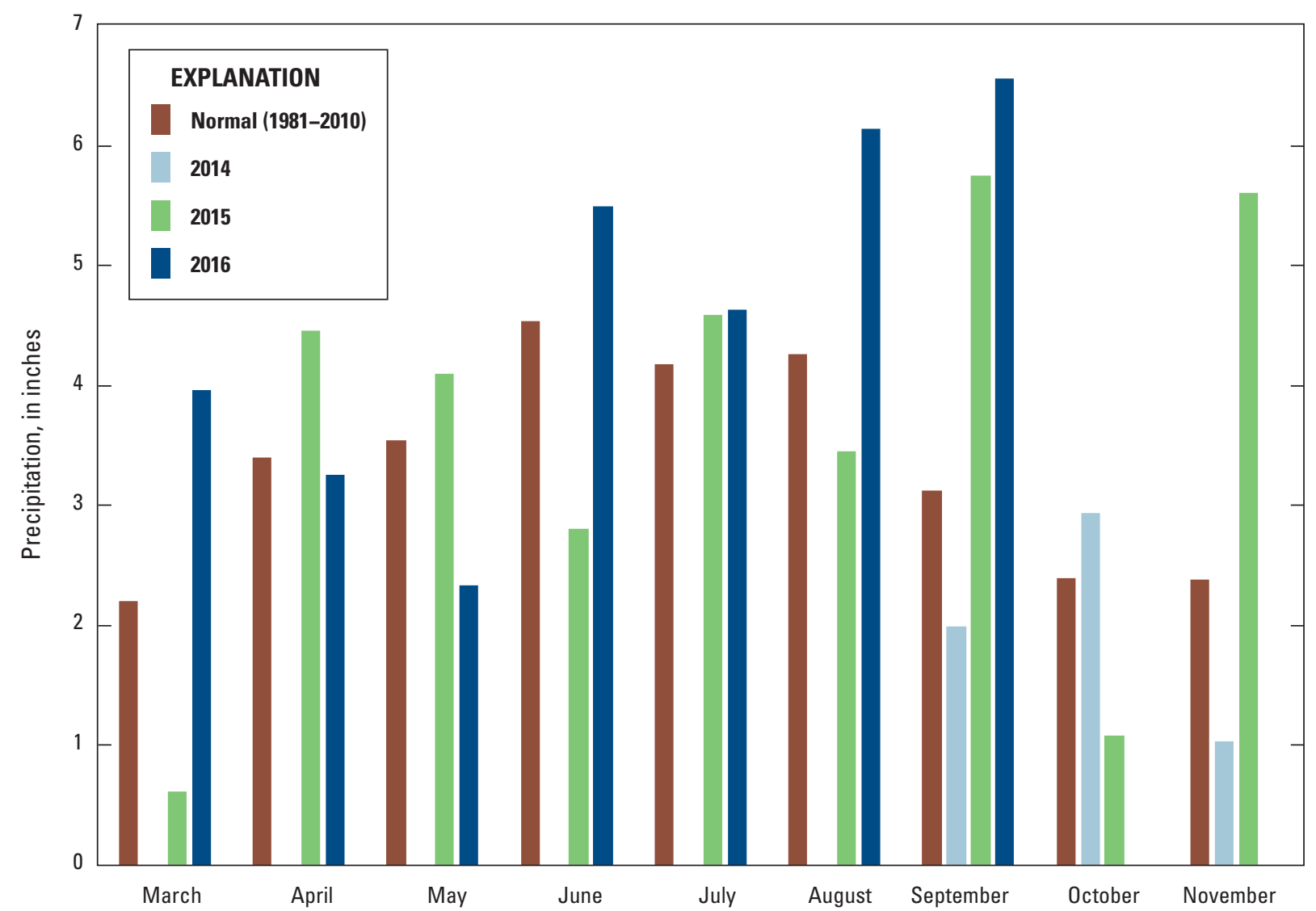

Figure 6. Monthly precipitation depth measured at the permeable pavement research facility from September 2014 through September 2016 compared to the 30-year normal (1981-2010).

having the least $(n=1)$ (table 3 ). The minimum requirements of precipitation depth and intensity for sufficient sample collection was, in most cases, greater than the minimum required to generate runoff. The summary statistics for sampled events listed in table 3 do not necessarily reflect minimum thresholds required for sample collection. Several runoff producing storm events were not sampled because of a combination of insufficient sample volume, equipment failure, or financial constraints. Therefore, the data listed in table 3 are to provide insight on the range of precipitation characteristics of sampled events as a subset of all monitored events.

Because the magnitude of precipitation events had some effect on the ability to collect a water-quality sample, the occurrence of larger storms could have exerted a seasonal bias that may be related to a higher clogging potential of permeable pavement. For this reason, seasonal differences in precipitation depth and intensity were tested by use of the KruskalWallis $k$ sample test (Helsel and Hirsch, 2002). Winter was excluded because of the low number of measured precipitation events $(n=3)$. If seasonal differences were significant ( $\alpha=0.05$ ), pairwise comparisons were made using Dunn's test with Bonferroni adjustment to determine seasons with greater storm depths or intensities (Winston and others, 2016b). Results of the test indicate significant seasonal differences in precipitation depth and 15-minute intensity. Spring precipitation depths and intensities were statistically lower than those measured in summer but were similar to those measured in fall (fig. 7). These data might indicate that clogging of permeable pavement could be accelerated during summer when energy is sufficient to transport fine and coarse particles in stormwater runoff; however, the availability and amount of source material should also be considered to determine if this factor is affecting performance. An analysis of seasonal concentrations from the parking lot (detailed later in this report) indicated that despite having higher precipitation intensities, concentrations of TSS in summer were generally lower than in spring. This result indicates that the amount of sediment available for washoff may be more limited in summer than in spring. 
Table 3. Summary statistics for monitored and sampled precipitation events by month.

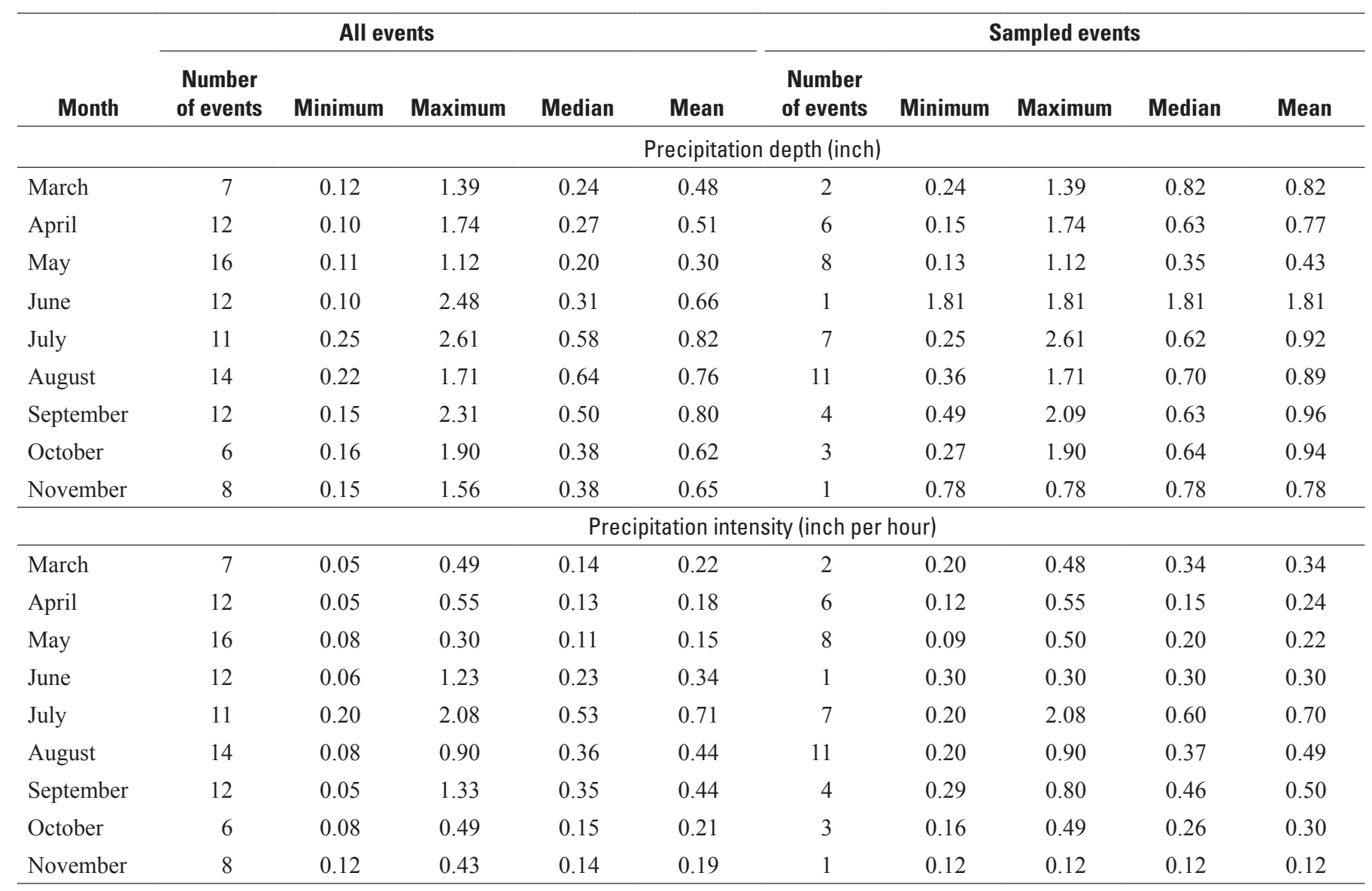



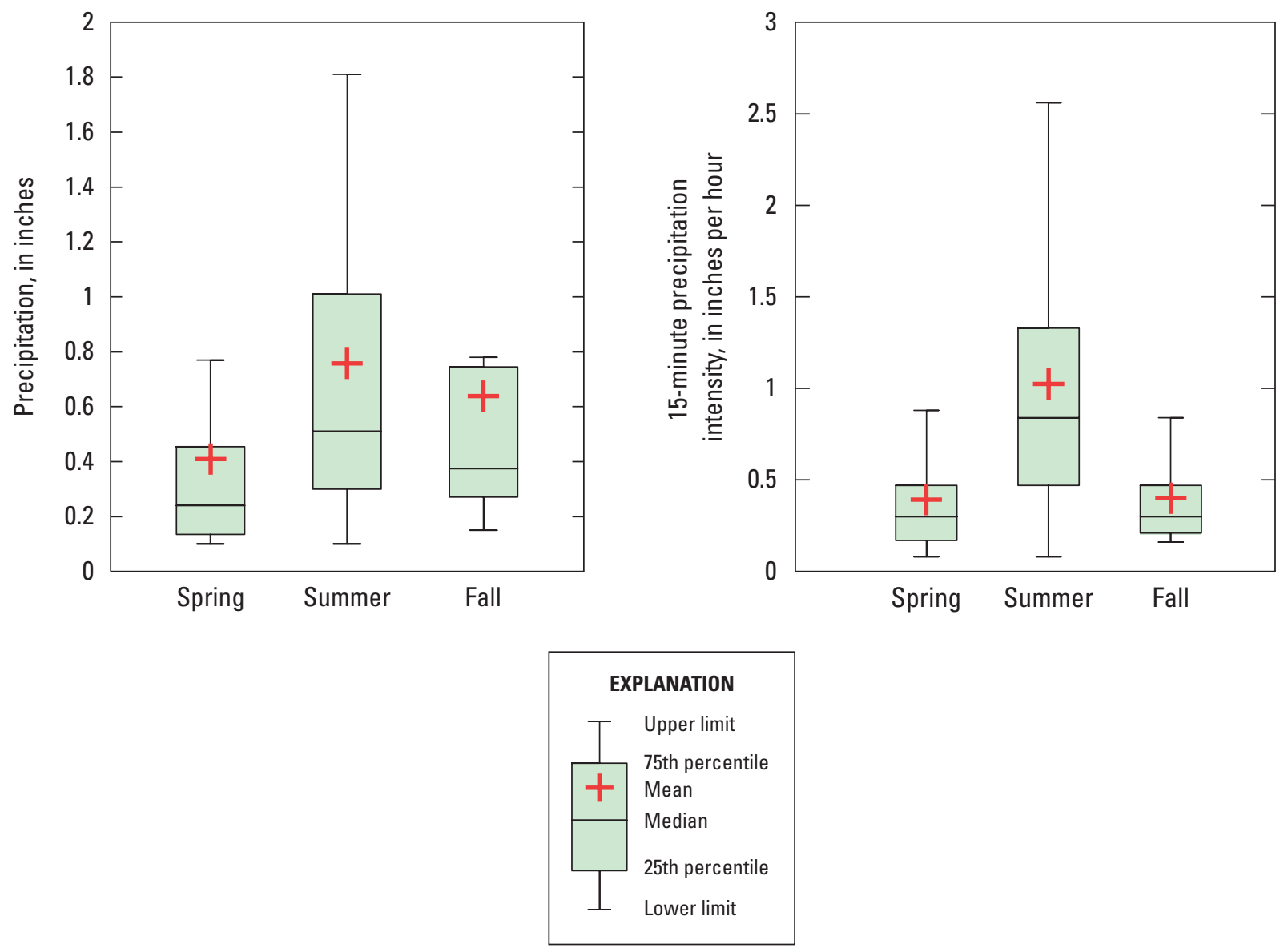

Figure 7. Box plots showing seasonal precipitation depth and intensity for monitored events at the permeable pavement research facility. 


\section{Runoff Volumes}

Summary statistics for event volumes measured at each permeable surface are presented in table 4. Each surface was separated into two categories representing the volume filtering through the surface to the underdrain or bypassing as overflow. The event volumes measured at each monitoring point are listed in Selbig (2018). The cumulative volume of runoff delivered from the flow splitter to each surface (the sum of underdrain and overflow) was largest in PA at 24,634 cubic feet $\left(\mathrm{ft}^{3}\right)$, followed by PIP and PC at 21,840 and 19,681 $\mathrm{ft}^{3}$, respectively. Although the differences seem minor, pairwise comparisons using Dunn's test indicate runoff volume influent to PA was significantly greater than PIP and PC ( $p$ value less than 0.05 ). Inspection of the flow splitter indicated slight differences in the flow path of influent volume from the parking lot for smaller, less intense runoff events that preferentially favored delivery to PA. As influent discharge increased (generally greater than 0.04 cubic foot per second), the flow splitter was better able to divide the volume of stormwater into equal proportions. Despite receiving more influent volume, PA hydraulically outperformed the other permeable surfaces, filtering 73 percent of total influent runoff. PIP and PC were not as efficient as PA, filtering 59 and 24 percent of influent runoff, respectively (table 4). Unlike PA and PIP, the majority of runoff influent to PC did not filter through the surface but rather bypassed as overflow. This overflow was mostly due to irregularities in the surface elevation created during the construction process. Despite best efforts to create a level surface, a small portion of the PC was deformed as the PC cured. Therefore, most of the runoff from small events collected in one area, leaving the remainder of the permeable surface exposed only to direct precipitation (fig. 8). Subsequently, this portion had a much higher loading rate than the rest of the PC surface and clogged very quickly. Histograms are presented in figure 9 for precipitation events generating overflow runoff volume from the PA, PC, and PIP test plots. More events with measurable overflow were in PC than in PA or PIP when precipitation depth was less than 0.5 inch. About 80 percent of the total volume of runoff influent to $\mathrm{PC}$ bypassed as overflow when precipitation depths were less than 0.5 inch compared to 44 and 24 percent for PIP and PA, respectively. Rainfall events with greater depth and intensity were capable of dosing the PC surface at a rate sufficient to disperse runoff across a larger surface area and, thereby, increasing infiltration. Attempts to remove embedded solids in the affected area and restore the infiltrative capacity of PC indicated temporary improvement (see "Effect of Maintenance" section) but were unable to correct the underlying problem.

Irregularities such as the settling of inadequately compacted aggregate may also have created opportunities to promote preferential pathways for runoff. The pathways identified for PC were the most obvious. However, pathways were later observed in PIP and were observed to a lesser degree in PA. Collins and others (2008) made similar conclusions when evaluating two variations of PIP. One of the PIP surfaces produced a higher amount of runoff despite having a higher void area and surface infiltration rate; therefore, differences in configurations and geometries may have influenced the way water flowed across each surface (Collins and others, 2008). Other than through visual observation, predicting where and when these pathways would emerge is difficult.

The ability to capture and filter runoff noticeably decreased with time for all permeable surfaces as the porous media clogged with sediment. Initially after construction, with the exception of PC, each permeable surface was able to filter most of the influent runoff; however, this capacity diminished with each successive runoff event (fig. 10). Because each curve in figure 10 represents the cumulative volume of runoff measured in the underdrain, the vertical distance between each curve and the line of equality can be interpreted as the cumulative volume measured as overflow. Therefore, a flatter slope indicates a greater proportion of overflow. PA was capable of infiltrating approximately $10,000 \mathrm{ft}^{3}$ of runoff before signs of clogging were present, more than twice the volume of PIP at approximately 4,000 $\mathrm{ft}^{3}$ (fig. 10). These thresholds were reached 12 and 9 months after construction of PA and PIP, respectively. PC showed signs of clogging soon after construction and did not improve with time. Removal and replacement of the PIP in July 2016 restored its infiltrative capacity, producing a noticeable increase in the slope of the cumulative influent/effluent curve (fig. 10). By the end of the monitoring period, PA had filtered 1.4 and 3.7 times more runoff than PIP and $\mathrm{PC}$, respectively.

Table 4. Summary statistics of runoff volume that filtered through to the underdrain or bypassed as overflow in the porous asphalt, pervious concrete, and permeable interlocking pavers test plots.

[PA, porous asphalt; PC, pervious concrete; PIP, permeable interlocking pavers; $<$, less than; all values are in cubic feet]

\begin{tabular}{lrrrrrrr}
\hline \multirow{2}{*}{ Statistic } & \multicolumn{3}{c}{ Underdrain volume } & & \multicolumn{3}{c}{ Overflow volume } \\
\cline { 2 - 4 } \cline { 6 - 8 } & PA & PC & PIP & & PA & PC & PIP \\
\hline Total & 17,918 & 4,799 & 12,862 & & 6,717 & 14,882 & 8,978 \\
Mean & 183 & 49 & 131 & & 69 & 152 & 93 \\
Median & 105 & 23 & 64 & & 10 & 80 & 25 \\
Maximum & 802 & 420 & 1,149 & & 688 & 980 & 1,031 \\
Minimum & 8 & 0 & $<1$ & & 0 & 0 & 0 \\
\hline
\end{tabular}




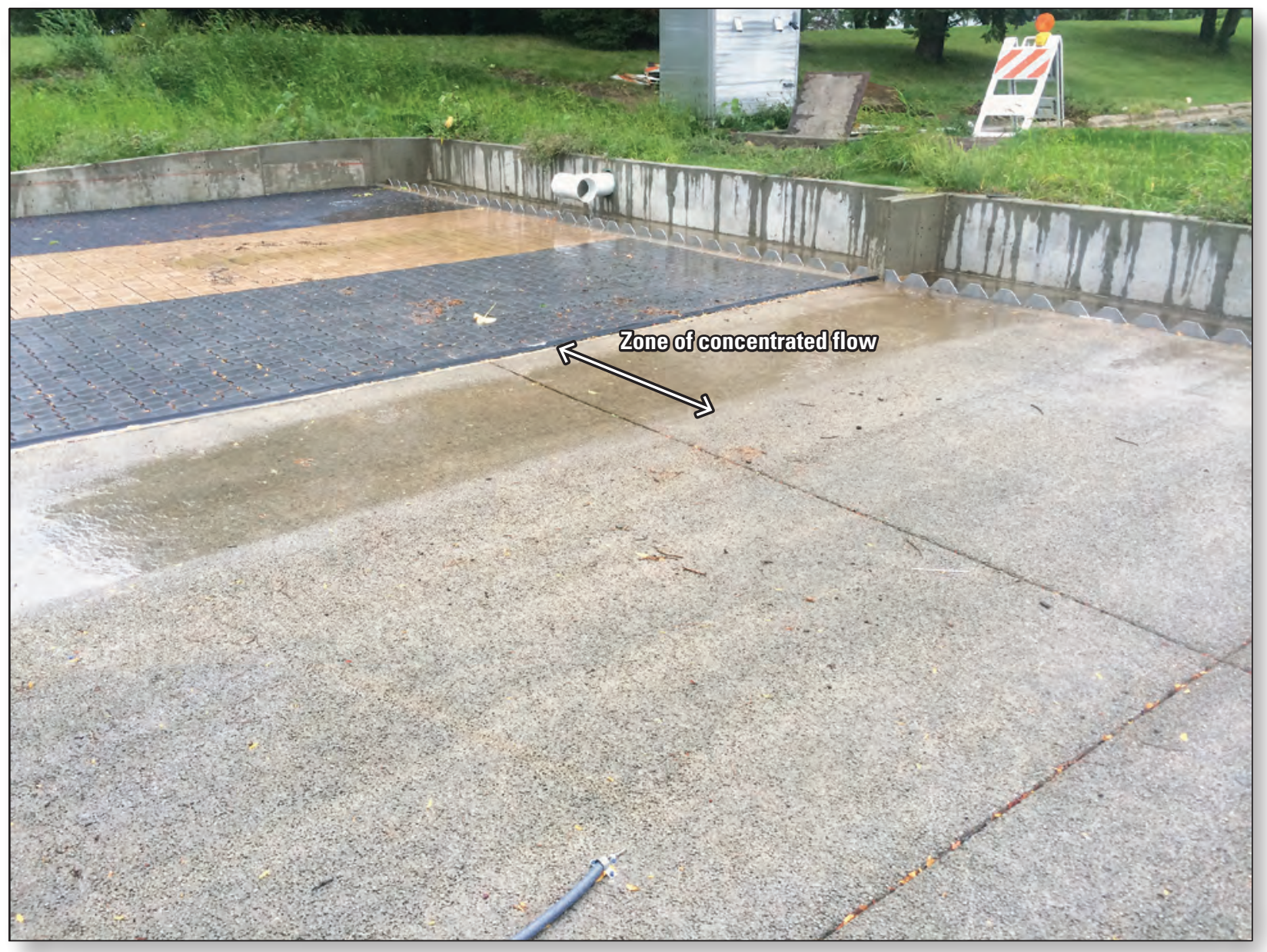

Figure 8. Photograph showing zone of concentrated flow for runoff in the pervious concrete test plot.

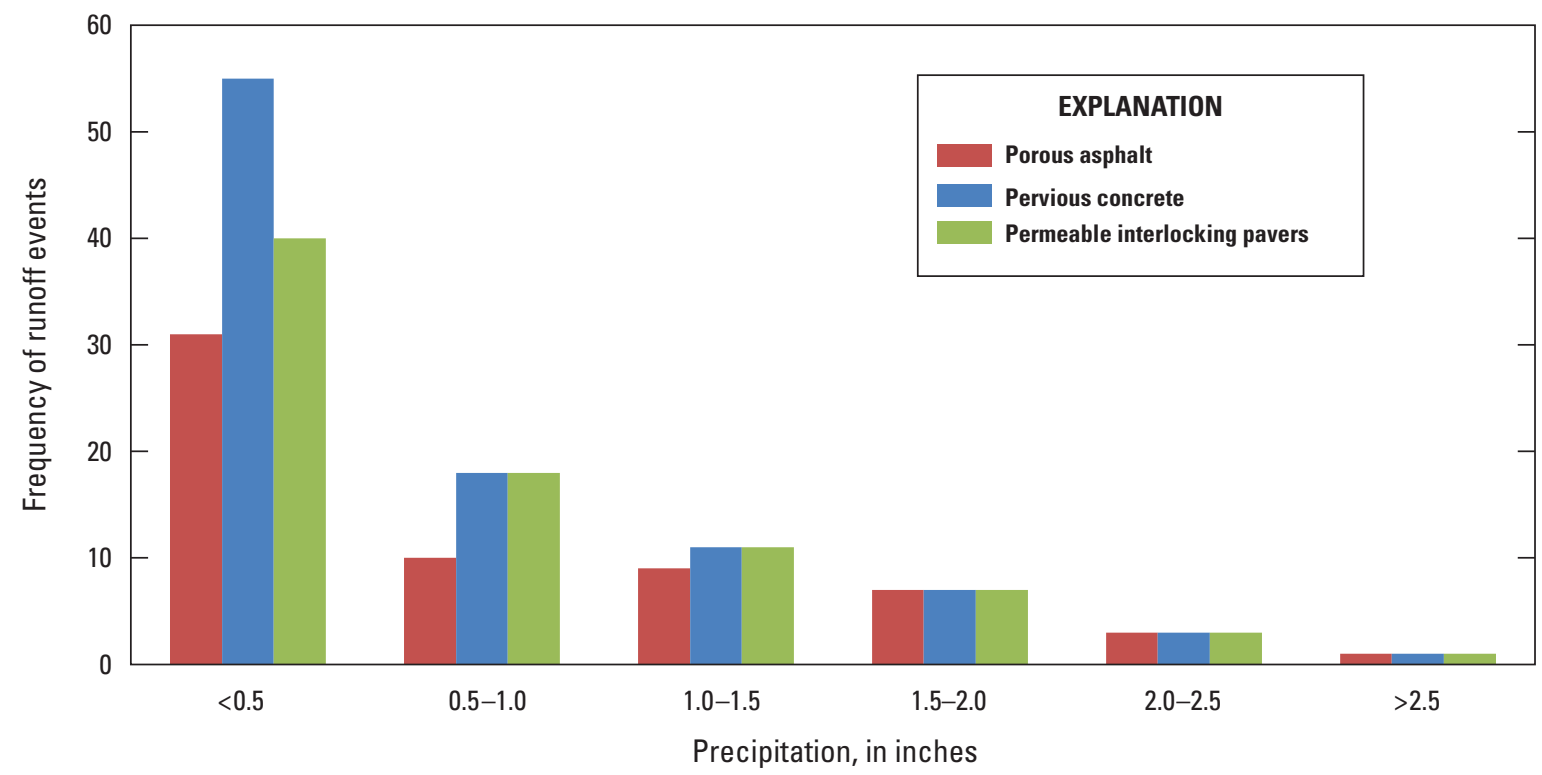

Figure 9. Histogram showing the frequency of measurable runoff bypassing as overflow in the porous asphalt, pervious concrete, and permeable interlocking pavers test plots with increasing event precipitation depth. 


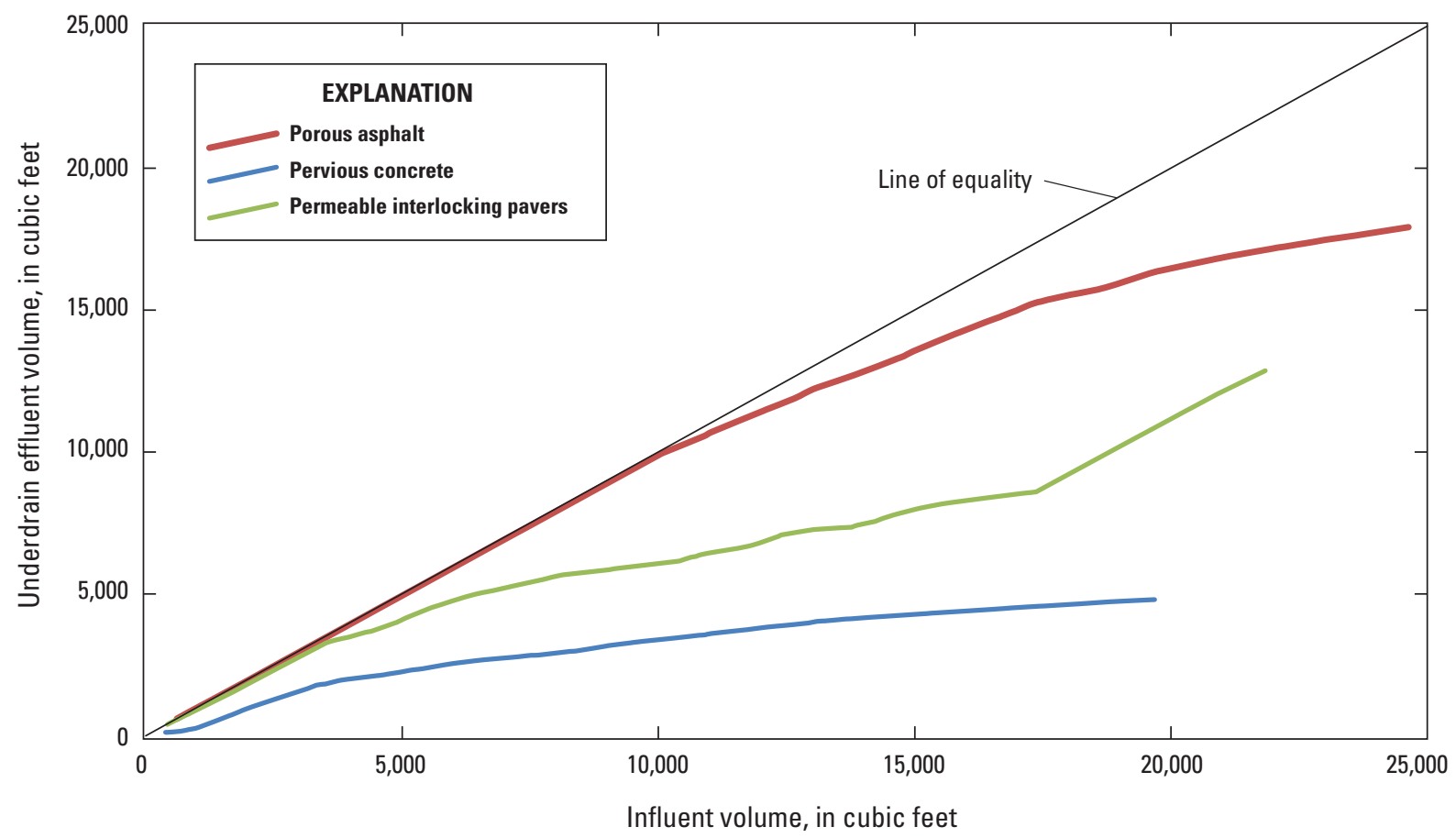

Figure 10. Cumulative influent runoff volume measured from the parking lot compared to the cumulative effluent volume measured in the underdrains of the porous asphalt, pervious concrete, and permeable interlocking pavers test plots.

\section{Infiltration Rates}

In general, surface infiltration rates of permeable pavement, along with contributing drainage area and pavement slope, could be used as predictors of the proportion of volume filtered or bypassed as overflow. Average infiltration rates of each permeable surface 1 month after construction were less than 325 inches per hour (in/hr), much lower than those reported in previous studies which in many cases exceeded $1,000 \mathrm{in} / \mathrm{hr}$ (Collins and others, 2008; Roseen and others, 2012). Much of the difference is likely due to about a 1-month period of sediment loading after final construction and before the first measurement of infiltration rates. Similar to these studies, however, average infiltration rates declined with time (table 5) as available void space in the permeable surface filled with sediment transported from the parking lot. As of June 2015, 10 months after construction, average infiltration rates for all permeable surfaces were still more than $100 \mathrm{in} / \mathrm{hr}$. Only a few months later, PC and PIP indicated a rapid decline in average infiltration rates, whereas the decline for PA was more gradual with only slight fluctuations through the remainder of the monitoring period.

Use of an average infiltration rate may be misleading on the overall performance of the permeable surface. A closer inspection of the spatial distribution of individual surface infiltration rates revealed that most (approximately 65 percent) of the PC and PIP surface was essentially clogged (less than $10 \mathrm{in} / \mathrm{hr}$ ) by October 2015, approximately 1 year after construction (fig. 11). The remaining 35 percent maintained a high rate of infiltration that skewed the overall average.
Table 5. Average surface infiltration rates in the porous asphalt, pervious concrete, and permeable interlocking pavers test plots.

[PA, porous asphalt; PC, pervious concrete; PIP, permeable interlocking pavers; - , not measured]

\begin{tabular}{lccc}
\hline \multirow{2}{*}{$\begin{array}{c}\text { Date } \\
\text { (month/day/ } \\
\text { year) }\end{array}$} & \multicolumn{2}{c}{ Average surface infiltration rate (inch per hour) } \\
\cline { 2 - 4 } \multicolumn{1}{c}{ PA } & PC & PIP \\
\hline $9 / 24 / 2014$ & 244 & 147 & 321 \\
$5 / 18 / 2015$ & 318 & 109 & 228 \\
$6 / 30 / 2015$ & 210 & 101 & 193 \\
$9 / 3 / 2015$ & 159 & 107 & 76 \\
$10 / 21 / 2015$ & 134 & 30 & 24 \\
$4 / 5 / 2016$ & 116 & 30 & 27 \\
${ }^{14} / 14 / 2016$ & 134 & 19 & 192 \\
$5 / 23 / 2016$ & 128 & 27 & 120 \\
${ }^{2} 7 / 12 / 2016$ & - & - & 815 \\
\hline
\end{tabular}

${ }^{1}$ Measurements taken after vacuum-enabled street cleaner maintenance on April 11, 2016.

${ }^{2}$ Measurement taken after replacement of PIP to restore infiltrative capacity. 
As expected, areas that received runoff first from the level spreader were also first to clog, the exception was PC, which failed along the aforementioned lateral portion of the test plot soon after construction. The decline in infiltrative capacity was less predictable as distance increased from the level spreader. Despite best efforts to create a level surface, a lack of uniform degradation in surface infiltration rates across the PC and PIP surface indicated that preferential flow left some sections subjected to only direct precipitation. The PA surface did not exhibit the same variability as PC and PIP. Although preferential pathways may have existed in the PA test plot, most of the runoff filtered through the surface within the first few feet of the level spreader (fig. 11).

\section{Effect of Maintenance}

Maintenance of permeable pavement, in the form of surface cleaning, is recommended at least twice per year using industry methods such as regenerative air or vacuum sweeping (Wisconsin Department of Natural Resources, 2016; Eisenberg and others, 2015). In Wisconsin, permeable pavements with surface infiltration rates less than $10 \mathrm{in} / \mathrm{hr}$ require action to restore infiltration rates by 50 percent (Wisconsin Department of Natural Resources, 2016). The numeric threshold of $10 \mathrm{in} /$ $\mathrm{hr}$, rather than the frequency of cleanings per year, was used to schedule when maintenance of each test plot was done as part of this study.

Maintenance of the PC surface was done in May 2015 as an attempt to restore the permeability of the surface caused by construction deformation. A high-powered, hand-held pressure washer was applied to the affected area followed by a highpowered vacuum suction to remove any dislodged material. The response in infiltration rates at select locations premaintenance and postmaintenance of the PC surface is shown in figure 12. Appreciable gains in infiltration rates were achieved at each location. Clogging was most pronounced near the influent level spreader, which, despite improvement from maintenance efforts, was still enough to limit infiltration rates to less than $15 \mathrm{in} / \mathrm{hr}$. Although postmaintenance infiltration rates in the affected area increased by more than 100 percent, the rates were still far lower than those measured at other locations within the PC surface. Although this level of maintenance effort might exceed normal industry recommendations, results indicate the potential outcome in extreme circumstances.

Based on the low average infiltration rate measured in October 2015, maintenance was done on the PIP surface by industry representatives. A cleaning approach similar to what might be done by a typical homeowner was used as a first attempt to restore surface infiltration rates. This process involved an initial clearing of debris using a high-powered leaf blower followed by sweeping using a bristled push broom. Any aggregate that was dislodged from the surface was removed and replaced with new aggregate. The variability in response to this activity based on premaintenance and postmaintenance infiltration measurements is shown in figure 13. The PIP configuration representing locations 1, 4, and 7 showed no improvement, a second paver configuration represented by locations 2,5 , and 8 had mixed results, and a third paver configuration represented by locations 3,6 , and 9 showed appreciable gains in postmaintenance infiltration rates. Despite little to no improvement in some areas of the PIP test plot, the overall average infiltration rate increased 114 percent from $24 \mathrm{in} / \mathrm{hr}$ premaintenance to $52 \mathrm{in} / \mathrm{hr}$ postmaintenance. Why each configuration of PIP produced varying improvement to surface infiltration rates is unclear. A clue may be in the geometry of the paver itself. Depending on the orientation of the channels between paver blocks, the bristles of the push broom may have been effective at penetrating and loosening the aggregate in one direction but not the other. The orientation of permeable channels between pavers may also have some bearing on how water is directed over a PIP surface.

Collins and others (2008) reported certain geometric patterns of PIP produced less runoff than others and determined that some paver configurations were better at forcing water to fill permeable channels before moving downslope. Additional research is needed to better characterize the role geometry may have on the hydraulic and water-quality performance of PIP.

On April 6, 2016, maintenance was done by use of a vacuum-assisted street cleaner. The sweeper operator passed across each surface twice using only the vacuum feature of the street cleaner. Postmaintenance measurements determined the average infiltration rate in the PIP to be $192 \mathrm{in} / \mathrm{hr}$, more than seven times greater than the premaintenance average of $27 \mathrm{in} / \mathrm{hr}$ (table 5). The street cleaner was unable to reach one-third of the PIP because of restrictions imposed by the concrete wall of the test site and wide wheelbase of the machine; therefore, results would have been greater had these restrictions not existed. Responses to maintenance in PC and PA were negligible with only slight changes from premaintenance levels (table 5). An appreciable increase in the infiltration rate of PIP but not PA or PC may have been related to the depth at which sediment becomes trapped in the permeable surface. The smaller void space of aggregate used in joints between PIP was able to retain more sediment at shallower depth than PA or PC. Visual inspection of the joint aggregate during replacement of the PIP in July 2016 indicated that most of the sediment seemed to be retained within approximately the first 0.5-1.0 inch (fig. 14). Lucke and Beecham (2011) similarly observed that most of sediment retained in PIP was in the upper 0.25 inch of aggregate bedding layer. Dierkes and others (2002) also determined that most pollutants were captured in the top 0.75 -inch layer of aggregates in the joints of PC blocks. The shallow penetration of sediment in PIP aggregate was, therefore, more easily removed by the vacuum suction of the street cleaner. Sediment in the PA and PC test plots may have penetrated deeper, outside the effect of the vacuum. However, Winston and others (2016b) suggested that most of the sediment captured by PA (and presumable PC) similarly resides within the top $1 \mathrm{inch}$. This idea was based on a significantly increased infiltration rate in PA after milling the top layer. Additional research is needed to determine the depth to which sediment penetrates into PA and PC. 
Porous asphalt

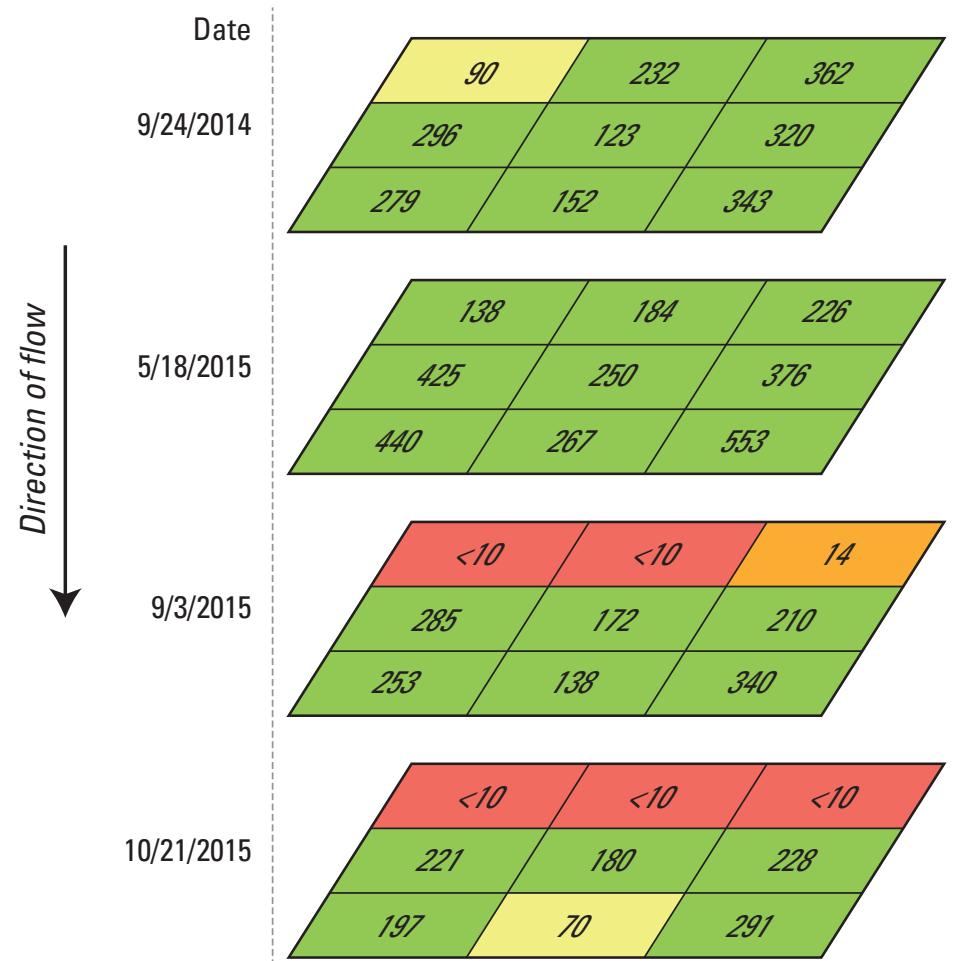

Pervious concrete
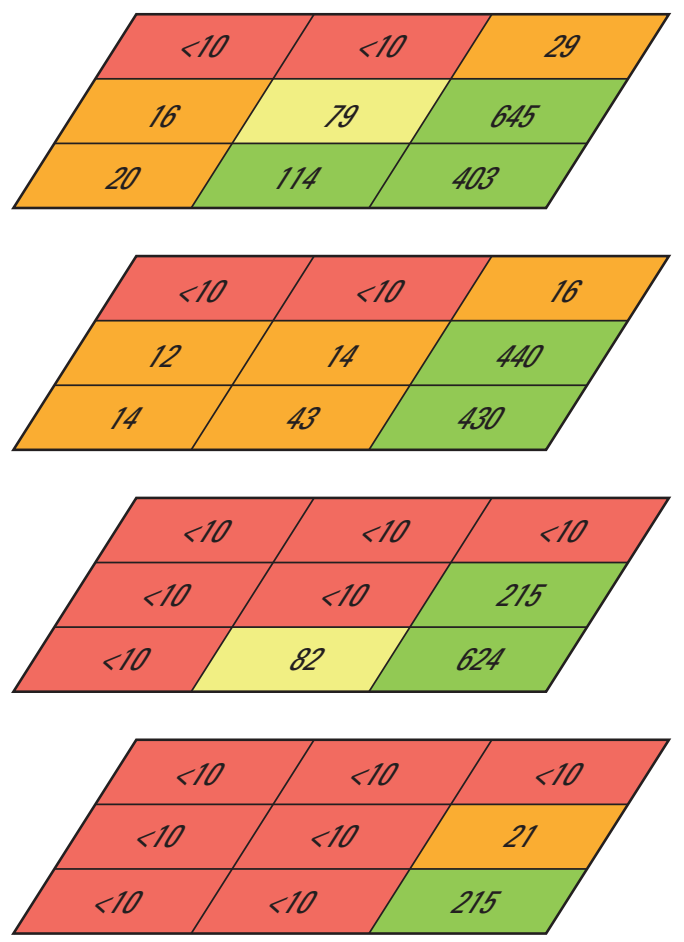

\section{EXPLANATION}

\section{Infiltration rate}

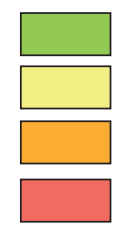

50 to $\leq 100$ inches per hour

$>10$ to $\leq 50$ inches per hour

$<10$ inches per hour
Permeable interlocking pavers
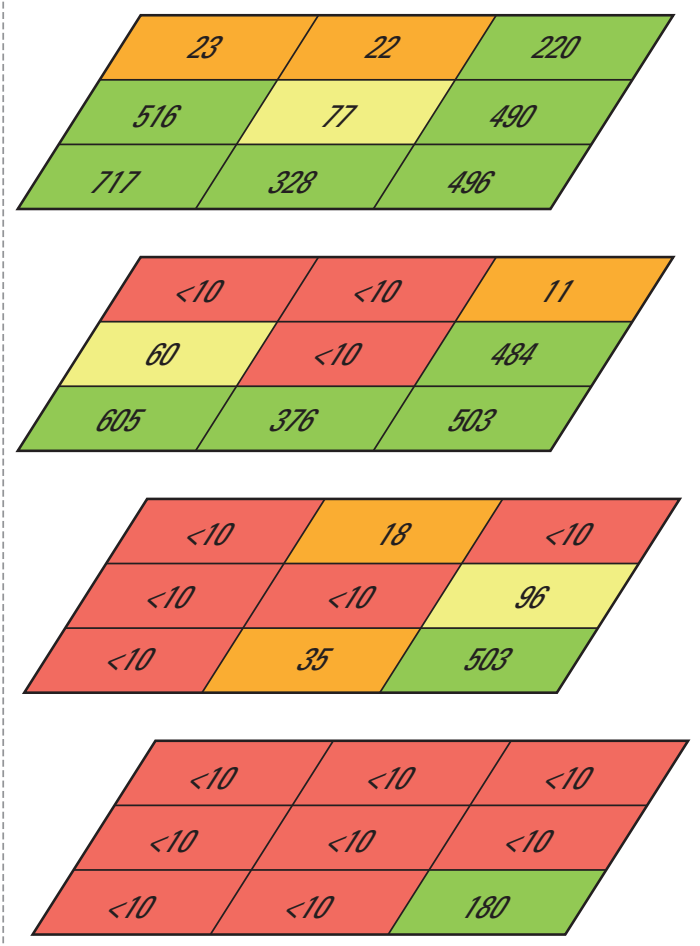

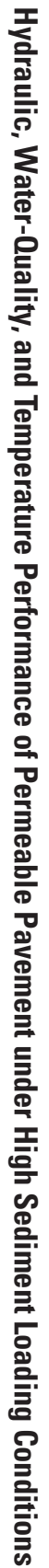

Figure 11. Heat map illustrating spatial distribution of infiltration rates in the porous asphalt, pervious concrete, and permeable interlocking pavers test plots, in plan view, from 1 month to about 1 year after construction. 


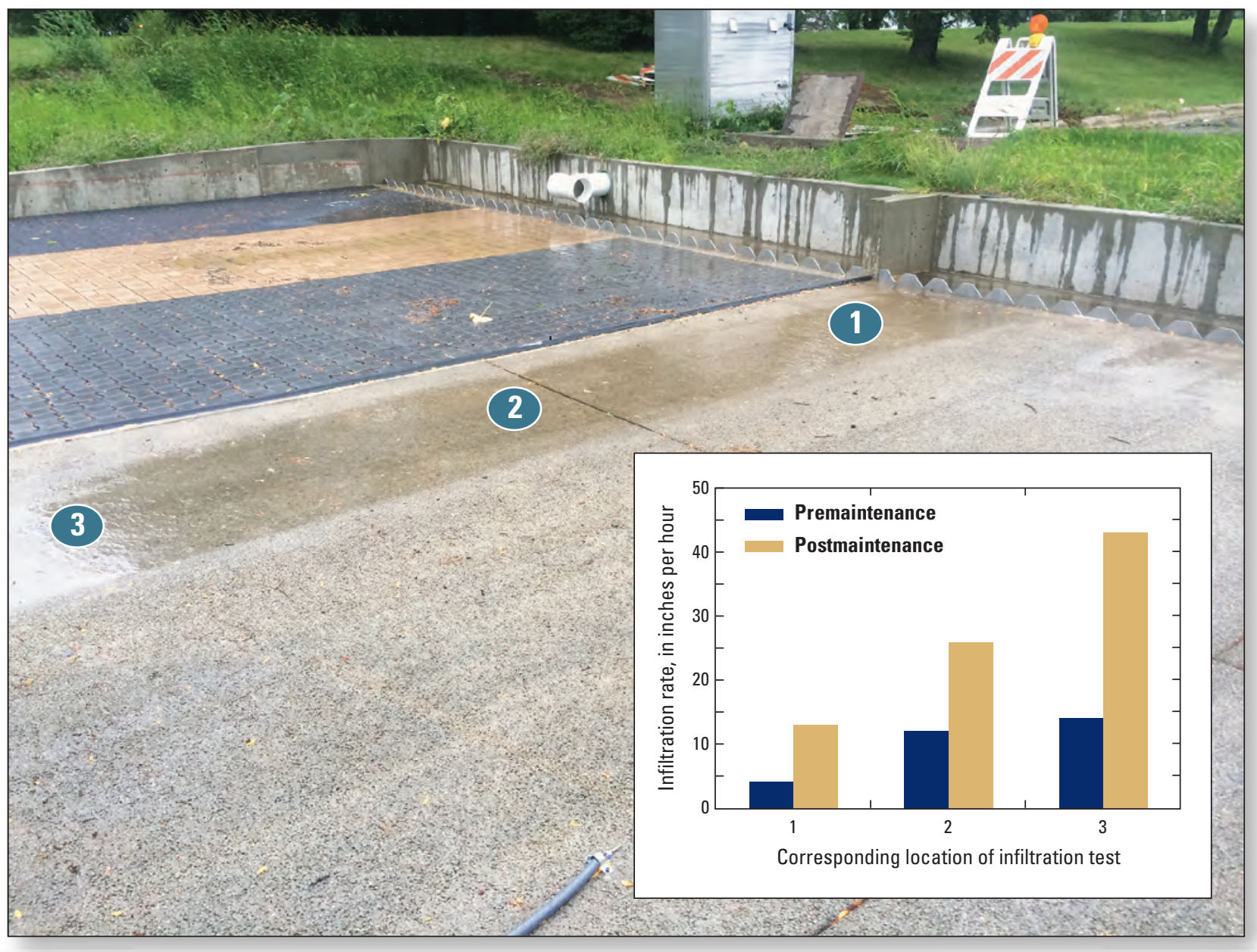

Figure 12. Response in infiltration rates at select locations premaintenance and postmaintenance of the pervious concrete surface. 


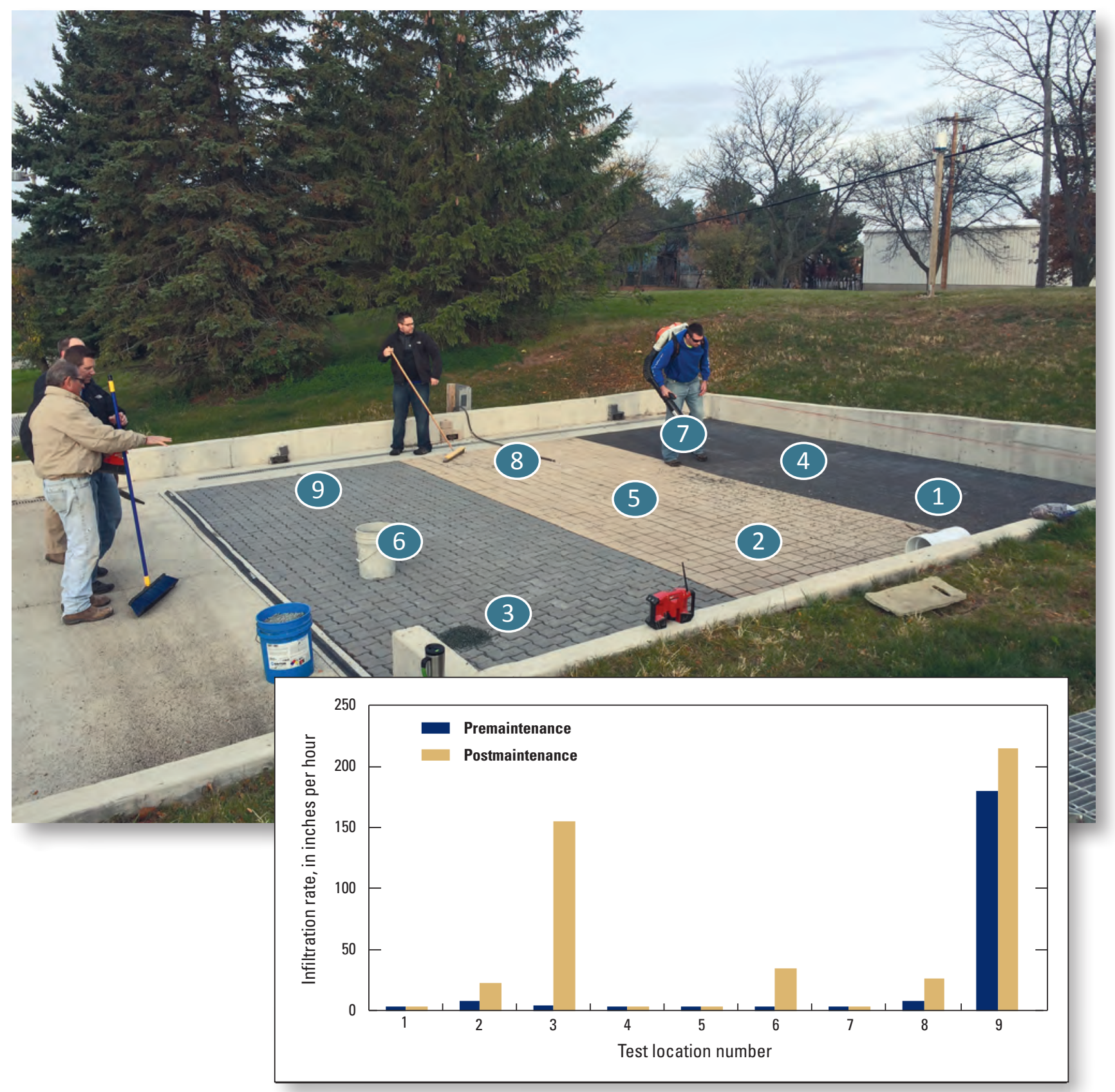

Figure 13. Spatial variation in infiltration rates before and after surface cleaning in the permeable interlocking pavers test plot. 


\section{Comparison of Water Quality}

Changes in the quality of stormwater were measured to determine how well each permeable surface could reduce pollutant concentrations and loads compared to untreated runoff from a parking lot. Of the 98 -runoff events measured at the permeable pavement test site (table 3), 43 were sampled for water quality. The remaining events were not sampled because of insufficient runoff volume at the underdrain and overflow monitoring points, equipment failure, laboratory error, or financial constraints. Sampled EMCs and loads are listed in Selbig (2018).

\section{Concentrations Measured from the Parking Lot}

A drainage ratio of 9.3:1 ensured a high volume of stormwater runoff was routed from the parking lot to the permeable surfaces. The large drainage ratio not only contributed an abundance of runoff volume but also an appreciable amount of suspended solids, likely because of the age and poor condition of the parking lot. These factors, when combined, produced a high rate of loading that greatly shortened the lifespan of each permeable surface. The median influent TSS concentration of 45 milligrams per liter $(\mathrm{mg} / \mathrm{L})$ was similar to what had been reported by other permeable pavement studies (Winston and others, 2016b; Drake and others, 2014a; Roseen and others, 2012); however, the mean concentration of $123 \mathrm{mg} / \mathrm{L}$ was much higher. The higher mean concentration was likely influenced by the amount of sediment used for traction control during the winter that later was washed from the parking lot during spring precipitation events (Selbig, 2018). Of the 10 highest TSS concentrations measured from the parking lot, 8 were collected during the spring, including the maximum of $677 \mathrm{mg} / \mathrm{L}$ in May 2016 (table 6). A Pearson correlation test was done to identify which climatic parameters (depth, intensity, and storm duration) might influence the concentration of TSS from the parking lot by season. Only 60-minute precipitation intensity indicated a significant positive correlation $(0.70, p$ less than 0.05$)$ to concentrations of TSS in the spring. A similar conclusion was made by Winston and others (2016a) when evaluating TSS concentrations from an asphalt parking lot in Ohio. This relation was not replicated in summer, where, despite having higher precipitation intensities (fig. 7), concentrations of TSS were generally lower than in spring. This result indicates that the parking lot may be source limited in the summer because precipitation events with higher intensity should have been able to mobilize more TSS. The high amount of residual material remaining on the parking lot after snowmelt contributed a high sediment load to the permeable pavement in the spring that accelerated its potential for clogging. This condition could potentially be avoided through implementation of pretreatment or timely source controls such as street cleaning.

\section{Concentrations Measured in the Underdrain}

With the exception of dissolved phosphorus and chloride, median concentrations of pollutants measured in the PA, PC, and PIP underdrain effluent were equal to or lower than those originating from the parking lot (table 6). Because concentrations were not normally distributed, a comparison of medians was more representative of the central tendency. Results of a Wilcoxon signed-rank test (Helsel and Hirsh, 1992) indicated a significant reduction between parking lot runoff and underdrain effluent concentrations for TSS, suspended sediment concentration (SSC), total phosphorus, Escherichia coli (E. coli), and Enterococci in the PA, PC, and PIP test plots at the 90-percent confidence level. Conversely, concentrations of dissolved phosphorus and chloride were significantly greater in the underdrain effluent than the parking lot influent at the 90-percent confidence level.

\section{Solids}

Median effluent concentrations of pollutants listed in table 6 were generally consistent, with slight differences among permeable surfaces. However, comparison to previous studies evaluating effluent concentrations from PA, PC, and PIP indicated substantial differences. Median concentrations of TSS were more than twice what had typically been previously reported (table 7). Most of the previous studies reported that effluent TSS concentrations ranged between 5 and $11 \mathrm{mg} / \mathrm{L}$, the exception being $24.9 \mathrm{mg} / \mathrm{L}$ reported by the International Stormwater Best Management Practices Database (Leisenring and others, 2014) based on a composite of eight studies. Variations in the physical characteristics of the contributing drainage area, configuration of paver geometry, gradations of aggregate, and design specifications for each permeable pavement may have been factors for differences in median TSS concentrations between the studies listed in table 7 and this study. Another factor may have been the influence of seasonally high sediment load delivered from the parking lot (as described in the previous section). A Pearson correlation test indicated a significantly positive correlation ( $p$ value less than 0.05 ) between influent and effluent concentration of TSS in the PA, PC, and PIP test plots. The greater frequency of runoff events with elevated TSS concentrations in this study, as indicated by a higher mean concentration, would support differences in effluent concentrations presented in table 7.

Permeable pavement has generally been reported to effectively reduce sediment and sediment-associated pollutants such as TSS and heavy metals. The primary mechanism is filtration by the permeable layer with underlying aggregate or exfiltration into native soils, or both. In some cases, however, permeable pavements have been noted to export TSS (Winston and others, 2016b). Although most of sampled runoff events 
Table 6. Summary statistics of event mean concentrations for pollutants measured from the parking lot and the underdrain and overflow monitoring points in the porous asphalt, pervious concrete, and permeable interlocking pavers test plots.

[n, number of observations; Min, minimum; Max, maximum; Std dev, standard deviation; TSS, total suspended solids; mg/L, milligram per liter; - , no data; PA, porous asphalt; PC, pervious concrete; PIP, permeable interlocking pavers; SSC, suspended sediment concentration; TP, total phosphorus; DP, dissolved phosphorus; Cl, chloride; E. coli; Escherichia coli; cfu/100 mL, colony-forming units per 100 milliliters; $<$, less than]

\begin{tabular}{|c|c|c|c|c|c|c|c|c|c|c|c|c|c|}
\hline \multirow{2}{*}{ Pollutant } & \multirow{2}{*}{ Pavement type } & \multicolumn{6}{|c|}{ Runoff/underdrain flow } & \multicolumn{6}{|c|}{ Overflow } \\
\hline & & $\mathbf{n}$ & Mean & Median & Min & Max & Std dev & $n$ & Mean & Median & Min & Max & Std dev \\
\hline \multirow[t]{4}{*}{ TSS (mg/L) } & Parking lot & 43 & 123 & 45 & 3 & 677 & 157 & - & - & - & - & - & - \\
\hline & PA & 41 & 48 & 24 & 6 & 372 & 66 & 11 & 48 & 25 & 14 & 183 & 58 \\
\hline & $\mathrm{PC}$ & 25 & 40 & 23 & 2 & 202 & 48 & 25 & 65 & 35 & 5 & 241 & 69 \\
\hline & PIP & 43 & 41 & 30 & 3 & 269 & 44 & 19 & 50 & 32 & 13 & 247 & 53 \\
\hline \multirow[t]{4}{*}{$\mathrm{SSC}(\mathrm{mg} / \mathrm{L})$} & Parking lot & 35 & 132 & 58 & 18 & 970 & 183 & - & - & - & - & - & - \\
\hline & $\mathrm{PA}$ & 28 & 34 & 24 & 4 & 118 & 27 & 9 & 65 & 31 & 18 & 317 & 90 \\
\hline & $\mathrm{PC}$ & 17 & 30 & 26 & 7 & 82 & 23 & 21 & 76 & 52 & 11 & 328 & 81 \\
\hline & PIP & 34 & 42 & 33 & 10 & 168 & 32 & 16 & 62 & 32 & 15 & 271 & 69 \\
\hline \multirow[t]{4}{*}{$\mathrm{TP}(\mathrm{mg} / \mathrm{L})$} & Parking lot & 42 & 0.24 & 0.16 & 0.04 & 0.88 & 0.19 & - & - & - & - & - & - \\
\hline & $\mathrm{PA}$ & 39 & 0.19 & 0.16 & 0.05 & 0.79 & 0.14 & 11 & 0.17 & 0.14 & 0.06 & 0.34 & 0.09 \\
\hline & $\mathrm{PC}$ & 22 & 0.16 & 0.13 & 0.06 & 0.48 & 0.10 & 24 & 0.21 & 0.17 & 0.08 & 0.49 & 0.11 \\
\hline & PIP & 42 & 0.19 & 0.17 & 0.05 & 0.62 & 0.11 & 18 & 0.18 & 0.17 & 0.07 & 0.42 & 0.08 \\
\hline \multirow[t]{4}{*}{$\mathrm{DP}(\mathrm{mg} / \mathrm{L})$} & Parking lot & 38 & 0.07 & 0.05 & 0.01 & 0.31 & 0.06 & - & - & - & - & - & - \\
\hline & $\mathrm{PA}$ & 33 & 0.11 & 0.07 & 0.01 & 0.70 & 0.12 & 10 & 0.09 & 0.08 & 0.03 & 0.24 & 0.06 \\
\hline & $\mathrm{PC}$ & 19 & 0.07 & 0.06 & 0.03 & 0.13 & 0.03 & 21 & 0.08 & 0.06 & 0.03 & 0.29 & 0.06 \\
\hline & PIP & 37 & 0.10 & 0.09 & 0.03 & 0.28 & 0.05 & 17 & 0.10 & 0.10 & 0.03 & 0.27 & 0.05 \\
\hline \multirow[t]{4}{*}{$\mathrm{Cl}(\mathrm{mg} /)$} & Parking lot & 34 & 8.9 & 2.4 & 1.3 & 115.0 & 20.3 & - & - & - & - & - & - \\
\hline & PA & 30 & 9.2 & 3.2 & 1.7 & 107.0 & 18.9 & 10 & 3.1 & 2.5 & 1.7 & 6.3 & 1.5 \\
\hline & $\mathrm{PC}$ & 15 & 14.9 & 3.7 & 1.5 & 94.7 & 24.8 & 19 & 4.7 & 2.8 & 1.8 & 13.0 & 3.4 \\
\hline & PIP & 32 & 10.6 & 3.4 & 1.7 & 122.0 & 22.5 & 15 & 3.6 & 2.4 & 1.4 & 11.1 & 2.8 \\
\hline \multirow{4}{*}{$\begin{array}{l}\text { E. } \text { coli } \\
\qquad(\mathrm{cfu} / 100 \mathrm{~mL})\end{array}$} & Parking lot & 29 & 7,080 & 2,420 & $<1$ & 32,550 & 9,535 & - & - & - & - & - & - \\
\hline & PA & 24 & 4,536 & 866 & $<1$ & 30,760 & 8,299 & 6 & 3,940 & 1,427 & 7 & 17,250 & 6,017 \\
\hline & $\mathrm{PC}$ & 9 & 1,759 & 633 & $<1$ & 9,600 & 3,014 & 18 & 2,511 & 830 & $<1$ & 13,960 & 3,920 \\
\hline & PIP & 28 & 3,847 & 1,162 & $<1$ & 28,510 & 6,421 & 13 & 4,896 & 1,300 & $<1$ & 21,430 & 7,160 \\
\hline \multirow{4}{*}{$\begin{array}{l}\text { Enterococci } \\
\qquad(\mathrm{cfu} / 100 \mathrm{~mL})\end{array}$} & Parking lot & 30 & 15,619 & 4,450 & 24 & 92,080 & 25,490 & - & - & - & - & - & - \\
\hline & $\mathrm{PA}$ & 26 & 8,161 & 2,504 & 26 & 92,080 & 18,208 & 6 & 30,508 & 8,955 & 29 & 129,970 & 45,820 \\
\hline & $\mathrm{PC}$ & 15 & 2,077 & 525 & 4 & 12,110 & 3,122 & 19 & 9,062 & 3,277 & 24 & 64,880 & 16,286 \\
\hline & PIP & 30 & 10,254 & 2,490 & 21 & 92,080 & 20,204 & 14 & 11,771 & 6,130 & 9 & 43,520 & 13,622 \\
\hline
\end{tabular}


Table 7. Comparison of median effluent event mean concentrations of total suspended solids, total phosphorus, and chloride in porous asphalt, pervious concrete, and permeable interlocking pavers from select previous studies.

$[\mathrm{mg} / \mathrm{L}$, milligram per liter; <, less than; PIP, permeable interlocking pavers; UNH, University of New Hampshire Stormwater Center; PC, pervious concrete; PA, porous asphalt; values reported from this study are in bold]

\begin{tabular}{|c|c|c|c|}
\hline Constituent & $\begin{array}{c}\text { Median } \\
\text { (mg/L) }\end{array}$ & Pavement & Source \\
\hline \multirow[t]{13}{*}{ Total suspended solids } & $<2$ & PIP & UNH (2012) \\
\hline & 5.1 & PIP & Van Seters (2007) \\
\hline & $5.7-9.2$ & PIP & Drake and others (2014a) \\
\hline & 8 & PIP & Bean and others (2007) \\
\hline & 30 & PIP & Present study \\
\hline & $97-154$ & PIP & Winston and others (2016b) \\
\hline & 6.5 & $\mathrm{PC}$ & Drake and others (2014a) \\
\hline & 11 & $\mathrm{PC}$ & UNH (2012) \\
\hline & 23 & PC & Present study \\
\hline & $<2$ & PA & UNH (2012) \\
\hline & 5 & PA & Roseen and others (2012) \\
\hline & 24 & PA & Present study \\
\hline & 24.9 & Composite $^{1}$ & Leisenring and others (2014) \\
\hline \multirow[t]{13}{*}{ Total phosphorus } & $<0.02$ & PIP & UNH (2012) \\
\hline & 0.02 & PIP & Van Seters (2007) \\
\hline & 0.03 & PIP & Drake and others $(2014 a)$ \\
\hline & $0.04-0.05$ & PIP & Winston and others (2016b) \\
\hline & ${ }^{2} 0.05$ & PIP & Bean and others (2007) \\
\hline & 0.17 & PIP & Present study \\
\hline & 0.12 & $\mathrm{PC}$ & Drake and others $(2014 a)$ \\
\hline & 0.13 & PC & Present study \\
\hline & 0.65 & $\mathrm{PC}$ & UNH (2012) \\
\hline & 0.04 & PA & UNH (2012) \\
\hline & 0.05 & PA & Roseen and others (2012) \\
\hline & 0.16 & PA & Present study \\
\hline & 0.10 & Composite $^{1}$ & Leisenring and others (2014) \\
\hline \multirow[t]{8}{*}{ Chloride } & 3.4 & PIP & Present study \\
\hline & 5.8 & PIP & Drake and others $(2014 a)$ \\
\hline & 61.4 & PIP & Van Seters (2007) \\
\hline & 24-101 & PIP & Winston and others (2016b) \\
\hline & 3.7 & PC & Present study \\
\hline & 5.8 & $\mathrm{PC}$ & Drake and others (2014a) \\
\hline & 3.2 & PA & Present study \\
\hline & 301 & PA & Roseen and others (2012) \\
\hline
\end{tabular}

${ }^{1}$ Median value for a composite of as many as eight studies.

${ }^{2}$ Mean value. 
had lower concentrations of TSS in the PA, PC, and PIP underdrains than the parking lot influent, some concentrations were higher (Selbig, 2018). Examination of EMCs detailed in Selbig (2018) indicates that effluent TSS increased shortly after construction of the study site. The cause of the increase was suspected to be a flushing of residual dust that had adhered to the aggregate during the construction process (Drake and others, 2014a). Approximately 1 month after construction of the study site, export of sediment from the aggregate was quantified in field tests where each permeable surface was flushed with clean water from a nearby fire hydrant. Waterquality samples collected at 5-minute intervals for $15 \mathrm{~min}$ utes indicated a decreasing concentration of TSS (table 8). Although this unmeasured contribution of sediment may have influenced effluent TSS concentrations early on, the impact likely declined with time as residual dust on the aggregate was washed away.

Table 8. Decreasing concentrations of total suspended solids measured in the underdrain with time when surfaces of porous asphalt, pervious concrete, and permeable interlocking pavers were flushed with water from a nearby fire hydrant, September 18, 2014.

[PA, porous asphalt; PC, pervious concrete; PIP, permeable interlocking pavers; $\mathrm{mg} / \mathrm{L}$, milligram per liter]

\begin{tabular}{cccc}
\hline $\begin{array}{c}\text { Cumulative time } \\
\text { (minutes) }\end{array}$ & $\begin{array}{c}\text { PA } \\
\text { (mg/L) }\end{array}$ & $\begin{array}{c}\text { PC } \\
\text { (mg/L) }\end{array}$ & $\begin{array}{c}\text { PIP } \\
\text { (mg/L) }\end{array}$ \\
\hline 5 & 337 & 315 & 358 \\
10 & 144 & 128 & 170 \\
15 & 38 & 68 & 86 \\
\hline
\end{tabular}

Another example of TSS export was documented by Winston and others (2016a). Later investigation revealed application of deicing salts in the winter and the resulting sodium adsorption ratio effect on underlying soils as the likely cause of the greater effluent TSS concentrations. An imbalance of sodium in relation to other cations in soils can cause deflocculation of clay particles and increase soil dispersion (Warrence and others, 2003; Mitchell and Soga, 2005; Kakuturu and Clark, 2015). Because of similarities in climate and the winter maintenance activities of the parking lot studied by Winston and others (2016a) and this study, a Pearson correlation test was used to determine if a link was between concentrations of TSS and chloride by season. Results of the test indicate a significantly positive correlation ( $p$ less than 0.05) in the underdrains of the PA and PC test plots in spring but not in summer (table 9). Similarly, chloride from the parking lot was positively correlated to TSS in the PA and PC underdrains but not TSS from the parking lot (table 9), meaning elevated concentrations of chloride from the parking lot may have contributed to the higher concentrations of TSS from the PA and PC underdrains. Fall was not evaluated because of the limited number of samples. These patterns were also observed in the PIP test plot but were not statistically significant. Application of deicing salts during winter seems to affect resulting effluent TSS concentrations as spring runoff events flush dispersed clays and silts captured in the permeable surface and aggregate or deposited on the surface of the impermeable membrane. The effect was less noticeable by summer as concentrations of chloride diminished. This process would be seasonal throughout the life of the pavement because the application of deicing agents is repeated each winter.

Table 9. Pearson correlation coefficients of chloride and total suspended solids concentrations in parking lot influent and porous asphalt, pervious concrete, and permeable interlocking pavers underdrain effluent.

[PA, porous asphalt; PC, pervious concrete; PIP, permeable interlocking pavers; - , no data; values in bold are significant at the 95 percent confidence level]

\begin{tabular}{|c|c|c|c|c|c|c|c|c|}
\hline \multirow{3}{*}{$\begin{array}{c}\text { Total } \\
\text { suspended solids }\end{array}$} & \multicolumn{8}{|c|}{ Chloride } \\
\hline & \multicolumn{4}{|c|}{ Spring } & \multicolumn{4}{|c|}{ Summer } \\
\hline & Parking lot & PA & PC & PIP & Parking lot & PA & PC & PIP \\
\hline Parking lot & 0.52 & 0.48 & 0.49 & 0.57 & 0.53 & -0.03 & 0.13 & -0.24 \\
\hline PIP & 0.25 & - & - & 0.37 & 0.30 & - & - & 0.01 \\
\hline $\mathrm{PC}$ & 0.89 & - & 0.84 & - & 0.48 & - & -0.42 & - \\
\hline PA & 0.86 & 0.83 & - & - & 0.47 & -0.15 & - & - \\
\hline
\end{tabular}




\section{Phosphorus}

Mean concentrations of total phosphorus measured in the underdrain effluent for all three permeable surfaces were lower than the parking lot (table 6). PA and PIP mean concentrations of total phosphorus were both reduced from 0.24 to $0.19 \mathrm{mg} / \mathrm{L}$ while PC mean concentrations of total phosphorus were reduced from 0.24 to $0.16 \mathrm{mg} / \mathrm{L}$. Conversely, median concentrations of total phosphorus in underdrain effluent were the same or slightly higher than those measured from the parking lot except for PC (table 6). Median and mean concentrations of dissolved phosphorous measured in the underdrain effluent of all three permeable pavements were the same or higher than those measured from the parking lot. Closer inspection of the ratio of total and dissolved phosphorus revealed a transition from a primarily particulate phase in the parking lot runoff to a primarily dissolved phase in the underdrain effluent because of filtration of TSS. Median values of dissolved phosphorus as a percent of total phosphorus were 60,67, and 62 percent for PA, PC, and PIP, respectively, compared to 33 percent for the parking lot. These values indicate that the PA, PC, and PIP surfaces were more efficient at filtering particle-bound phosphorus than dissolved phosphorus.

Despite similarities among permeable pavements, median effluent concentrations of total phosphorus observed in this study differed from what had previously been reported for PA, PC, and PIP. However, PC was an exception, with observed values almost identical to those reported by Drake and others (2014a) but less than one-quarter of what had been reported by the University of New Hampshire Stormwater Center (2012) (table 7). Concentrations of total phosphorus measured in the effluent of PA and PIP test plots were outside the range described by prior studies, oftentimes exceeding reported values by a factor of three. Some of the discrepancy could be due to differences in the magnitude of influent concentration. For example, Winston and others (2016a) reported a median influent concentration of total phosphorus from an asphalt parking lot to be $0.05 \mathrm{mg} / \mathrm{L}$ compared to $0.17 \mathrm{mg} / \mathrm{L}$ reported by Drake and others (2014a) and $0.16 \mathrm{mg} / \mathrm{L}$ observed in this study (table 6). Appreciable reductions in phosphorus and other pollutants may be beyond the removal capabilities of permeable pavement when influent concentrations are already low. Although influent concentrations were at the higher end of the reported range of prior studies, the PA, PC, and PIP test plots were unable to reduce total phosphorus below the waterquality target of $0.075 \mathrm{mg} / \mathrm{L}$ for surface waters in Wisconsin (Wisconsin Administrative Code, 2010).

\section{Chloride}

Mean and median effluent concentrations of chloride in all three permeable surfaces were higher than parking lot runoff (table 6) but lower than what had been reported in previous studies (table 7). More than 80 percent of all paired waterquality samples had a higher concentration of chloride in the underdrain effluent than the influent (Selbig, 2018). A pattern of elevated chloride concentrations from March through May in parking lot influent and underdrain effluent followed by a gradual decline through the summer also are indicated in Selbig (2018). None of the concentrations exceeded the U.S. Environmental Protection Agency chronic toxicity criterion of $230 \mathrm{mg} / \mathrm{L}$ (U.S. Environmental Protection Agency, 2012a). The application of deicers during winter might initially have been concentrated in parking lot runoff then diluted with subsequent runoff events. This result is consistent with Drake and others (2014b) who observed concentrations of chloride in winter to range between approximately 100 and 1,000 mg/L, an order of magnitude larger than nonwinter. Drake and others (2014b) indicate that some detention of deicer runoff is possible based on the ability of permeable pavements to retain small amounts of meltwater with high concentrations of chloride. Additional reductions were also noted through partial infiltration into native soils. Unlike results from Drake and others (2014b), results from this study do not indicate attenuation or mitigation of chloride concentrations by the permeable pavements - a conclusion made by most similar studies (Winston and others, 2016b; Roseen and others, 2012). Because the samples collected in March and April represent runoff from precipitation instead of snowmelt, resulting chloride concentrations may have already undergone some level of dilution. Snowmelt samples collected during winter may offer additional insight on the temporary storage of chloride in small amounts of meltwater and the dynamic exchange between seasonal retention and flushing of chloride in permeable pavement.

\section{Bacteria}

Compared to parking lot influent, mean and median concentrations of E. coli and Enterococci in the underdrain effluent decreased as runoff filtered through the permeable layer and aggregate base (table 6). Results indicated that PC had the largest reduction in concentration among the pavements but also had the fewest number of samples. Despite a reduction, mean and median effluent concentrations were still above the U.S. Environmental Protection Agency recreational water-quality criteria of 410 and 130 colony-forming units per 100 milliliters for E. coli and Enterococci, respectively (U.S. Environmental Protection Agency, 2012b), although concentrations occasionally were reduced to below detection limits (Selbig, 2018). Few data are available to compare with previous research. The International Stormwater Best Management Practices Database (Leisenring and others, 2014), a synthesis of the water-quality performance of stormwater best management practices, reports more than 200 EMCs from 8 different permeable pavement studies but none for Enterococci or E. coli. 


\section{Concentrations Measured in the Overflow}

Summary statistics for overflow concentrations are detailed in table 6. Median concentrations of measured pollutants for PA, PC, and PIP overflow were similar to those measured in their respective underdrains. Comparisons of paired concentrations between the underdrain and overflow for the PA, PC, and PIP, using the Wilcoxon signed-rank test at the 90-percent confidence level, indicated mixed results. Concentrations measured in the overflow of $\mathrm{PC}$ were greater than the underdrain for all but dissolved phosphorus, which indicated no difference. Conversely, results indicated no difference between PIP underdrain and overflow concentrations for all but SSC and chloride, which were greater in overflow. Results for PA indicated no difference for total phosphorus, chloride, and Enterococci but was greater in the overflow for dissolved phosphorus, TSS, SSC, and E. coli. Some of the inconsistencies could stem from fewer samples collected in overflow, especially for PA. Another explanation could be the dynamics between losses from physical processes and additions from unknown sources. The dissipation of energy as runoff is dispersed across the permeable surface allowing for some removal of solid-phase material through settling as a secondary form of treatment; however, pollutant concentrations also could increase through atmospheric deposition or organic detritus from nearby vegetation.

\section{Comparison of Loads}

Concentrations of pollutants measured from the parking lot were assumed to remain constant as runoff was split and delivered to each permeable pavement test plot. Because of slight variations in runoff volume amongst each test plot and between runoff events, calculation of pollutant loads that were influent to each test plot required an adjustment based on the proportion of flow measured in the PA, PC, and PIP underdrain and overflow flumes (see "Data Analyses" section). Because water was not allowed to exfiltrate into native soils, the percent change, herein referred to as removal efficiency, between the sum of paired influent and effluent loads represents the pollutant removal capabilities (or lack thereof) of only the permeable surface and aggregate base. Removal efficiencies were also computed for the underdrain and overflow separately to better understand the filtering capacity of the permeable surface and aggregate base independent of what may have bypassed as overflow. Removal efficiencies for each permeable pavement, as a complete system, were also determined by combining the underdrain and overflow loads.

\section{Solids}

TSS and SSC loads were significantly reduced ( $p$ less than 0.05) in the PA, PC, and PIP underdrain effluent when compared to untreated runoff (table 10). PA and PIP results indicated similar removal efficiencies for SSC ( 77 and 63 percent, respectively) and TSS (65 and 69 percent, respectively). PC was capable of removing the largest amount of solids at 82 and 80 percent for SSC and TSS, respectively. Unlike PA and PIP, however, the majority of TSS and SSC load influent to PC bypassed as overflow. Much of the divergence of flow in the PC can be attributed to its unleveled surface causing a narrow band to clog quickly. For runoff that did infiltrate through the PC, the combination of void space and depth of PC indicated that 80 percent of TSS was removed. By comparison, PA having a larger void space than PC or PIP, allowed more runoff to infiltrate but was unable to capture and retain as much TSS.

Based on visual observation, the majority of captured solids in PIP seemed to be concentrated within the first inch of the surface (fig. 14). The shallow penetration of solids into the aggregate used between PIP joints indicates efficient trapping of solids, which accelerated the rate of clogging. Thus, the filtering capacity of PIP can be restored through removal and replacement of the aggregate. The ability to promote sediment removal in PIP through restorative maintenance is indicated by increased infiltration rates after several passes by the vacuum street cleaner (table 5). Sediment captured by PA and PC may reside deeper in the permeable surface, outside the reach of vacuum suction.

Similar to the underdrains, sediment was significantly reduced in overflow (with the exception of PA), though to a lesser degree. PIP overflow indicated slightly higher removal efficiencies for TSS than PC with 50 and 42 percent reduction, respectively. Removal efficiencies for SSC were similarly greater in PIP than PC but approximately one-half of what was reported for TSS. The removal of sediment as a secondary form of treatment by permeable pavement is likely due to the dissipation of energy as runoff spreads across the permeable surface allowing for a portion of sediment to settle out of suspension. Deposition of sediment may have also come from unmeasured sources, such as the atmosphere.

\section{Phosphorus}

Only PC was able to significantly reduce the load of total phosphorus measured in the underdrain ( $p$ less than 0.05). PIP and PA results indicated 14 and 23 percent reductions in total phosphorus load, respectively, which were not significant. Similar to TSS and SSC, the sum of the total phosphorus load to the PC test plot was much less than PA or PIP with a disproportionate amount bypassing as overflow. The load of total phosphorus that bypassed as overflow generally indicated little to no change from the influent load for all three permeable surfaces, the exception being PA, which indicated an 11 percent increase ( $p$ less than 0.05) in total phosphorus load. Slight reductions, and in some cases increases, of total phosphorus load could be influenced by the proportion in the dissolved phase. Dissolved phosphorus and chloride, pollutants that are more mobile and difficult to remove, indicated significant increases in load measured in the underdrain and overflow (table 10). 
Table 10. Summary statistics of pollutant loads with calculated removal efficiencies and statistical significance at the underdrain and overflow monitoring points in the porous asphalt, pervious concrete, and permeable interlocking pavers test plots.

[PA, porous asphalt; PC, pervious concrete; PIP, permeable interlocking pavers; Influent ${ }_{\text {Adj }}$, adjusted influent load; n, number of observations; Min, minimum; Max, maximum; Std dev, standard deviation; RE, removal efficiency; NA, not applicable; \%, percent; negative RE values indicate pollutant export; values in bold indicate a significant increase (+) or decrease (-) in load at the 95 percent confidence level]

\begin{tabular}{|c|c|c|c|c|c|c|c|c|c|c|c|c|}
\hline \multirow{3}{*}{ Statistic } & \multicolumn{4}{|c|}{ PA } & \multicolumn{4}{|c|}{ PC } & \multicolumn{4}{|c|}{ PIP } \\
\hline & \multicolumn{2}{|c|}{ Underdrain } & \multicolumn{2}{|c|}{ Overflow } & \multicolumn{2}{|c|}{ Underdrain } & \multicolumn{2}{|c|}{ Overflow } & \multicolumn{2}{|c|}{ Underdrain } & \multicolumn{2}{|c|}{ Overflow } \\
\hline & Influent $_{\text {Adj }}$ & Effluent & Influent $_{\mathrm{Adj}}$ & Effluent & Influent $_{\text {Adj }}$ & Effluent & Influent $_{\mathrm{Adj}}$ & Effluent & Influent $_{\mathrm{Adj}}$ & Effluent & Influent $_{\text {Adj }}$ & Effluent \\
\hline \multicolumn{13}{|c|}{ Total suspended solids, in grams } \\
\hline $\mathrm{n}$ & 41 & 41 & 11 & 11 & 25 & 25 & 25 & 25 & 43 & 43 & 19 & 19 \\
\hline Min & 10 & 9 & 18 & 31 & 5 & 4 & 11 & 15 & 11 & 14 & 13 & 13 \\
\hline $\operatorname{Max}$ & 8,489 & 3,530 & 2,202 & 1,073 & 3,927 & 655 & 5,617 & 3,603 & 6,964 & 2,037 & 4,532 & 2,980 \\
\hline Median & 213 & 132 & 190 & 164 & 108 & 28 & 154 & 116 & 153 & 98 & 102 & 71 \\
\hline Mean & 974 & 344 & 384 & 249 & 476 & 95 & 593 & 345 & 675 & 208 & 395 & 240 \\
\hline Std dev & 1,993 & 655 & 597 & 285 & 1,021 & 172 & 1,224 & 732 & 1,475 & 332 & 986 & 648 \\
\hline Sum & 39,923 & 14,096 & 4,229 & 2,741 & 11,903 & 2,375 & 14,826 & 8,637 & 29,039 & 8,942 & 9,050 & 4,560 \\
\hline $\mathrm{RE}$ & NA & $65 \%$ & NA & $35 \%$ & NA & $80 \%$ & NA & $42 \%$ & NA & $69 \%$ & NA & $50 \%$ \\
\hline$p$ value & NA & $<0.01(-)$ & NA & 0.43 & NA & $0.02(-)$ & NA & $<0.01(-)$ & NA & $<0.01(-)$ & NA & $<0.01(-)$ \\
\hline \multicolumn{13}{|c|}{ Suspended sediment, in grams } \\
\hline $\mathrm{n}$ & 29 & 28 & 9 & 9 & 17 & 17 & 21 & 21 & 34 & 34 & 16 & 16 \\
\hline Min & 34 & 9 & 35 & 51 & 25 & 7 & 31 & 28 & 25 & 14 & 76 & 31 \\
\hline Max & 10,222 & 1,866 & 2,224 & 1,858 & 4,169 & 602 & 5,672 & 4,904 & 7,316 & 2,364 & 4,576 & 3,269 \\
\hline Median & 372 & 149 & 250 & 185 & 143 & 40 & 317 & 200 & 240 & 166 & 154 & 124 \\
\hline Mean & 1,495 & 346 & 530 & 467 & 637 & 118 & 750 & 536 & 935 & 348 & 507 & 357 \\
\hline Std dev & 2,807 & 503 & 652 & 572 & 1,223 & 176 & 1,316 & 1,039 & 1,807 & 553 & 1,062 & 771 \\
\hline Sum & 43,054 & 9,699 & 4,768 & 4,204 & 10,834 & 1,998 & 15,748 & 11,264 & 31,773 & 11,830 & 8,105 & 5,709 \\
\hline $\mathrm{RE}$ & NA & $77 \%$ & NA & $12 \%$ & NA & $82 \%$ & NA & $28 \%$ & NA & $63 \%$ & NA & $30 \%$ \\
\hline$p$ value & NA & $<0.01(-)$ & NA & 0.14 & NA & $0.02(-)$ & NA & $<0.01(-)$ & NA & $<0.01(-)$ & NA & $<0.01(-)$ \\
\hline \multicolumn{13}{|c|}{ Total phosphorus, in grams } \\
\hline $\mathrm{n}$ & 39 & 39 & 11 & 11 & 22 & 22 & 24 & 24 & 42 & 42 & 18 & 18 \\
\hline Min & 0.06 & 0.09 & 0.11 & 0.23 & 0.06 & 0.08 & 0.20 & 0.18 & 0.12 & 0.12 & 0.09 & 0.06 \\
\hline Max & 8.88 & 3.95 & 3.09 & 3.51 & 4.11 & 1.29 & 5.70 & 4.66 & 7.21 & 6.28 & 4.60 & 3.70 \\
\hline Median & 0.78 & 0.69 & 0.61 & 0.88 & 0.32 & 0.21 & 0.54 & 0.78 & 0.45 & 0.63 & 0.43 & 0.56 \\
\hline Mean & 1.63 & 1.26 & 0.97 & 1.07 & 0.79 & 0.38 & 0.96 & 0.94 & 1.25 & 1.08 & 0.68 & 0.69 \\
\hline Std dev & 2.12 & 1.18 & 0.91 & 0.92 & 1.11 & 0.37 & 1.19 & 0.90 & 1.65 & 1.25 & 0.99 & 0.78 \\
\hline Sum & 64 & 49 & 11 & 12 & 17 & 8 & 23 & 23 & 52 & 45 & 12 & 12 \\
\hline $\mathrm{RE}$ & NA & $23 \%$ & NA & $-11 \%$ & NA & $51 \%$ & NA & $1 \%$ & NA & $14 \%$ & NA & $-2 \%$ \\
\hline$p$ value & NA & 0.23 & NA & $0.02(+)$ & NA & $<0.01(-)$ & NA & 0.91 & NA & 0.35 & NA & 0.78 \\
\hline
\end{tabular}


Table 10. Summary statistics of pollutant loads with calculated removal efficiencies and statistical significance at the underdrain and overflow monitoring points in the porous asphalt, pervious concrete, and permeable interlocking pavers test plots.-Continued

[PA, porous asphalt; PC, pervious concrete; PIP, permeable interlocking pavers; Influent ${ }_{\text {did }}$, adjusted influent load; $n$, number of observations; Min, minimum; Max, maximum; Std dev, standard deviation; RE, removal efficiency; NA, not applicable; \%, percent; negative RE values indicate pollutant export; values in bold indicate a significant increase (+) or decrease (-) in load at the 95 percent confidence level]

\begin{tabular}{|c|c|c|c|c|c|c|c|c|c|c|c|c|}
\hline \multirow{3}{*}{ Statistic } & \multicolumn{4}{|c|}{ PA } & \multicolumn{4}{|c|}{ PC } & \multicolumn{4}{|c|}{ PIP } \\
\hline & \multicolumn{2}{|c|}{ Underdrain } & \multicolumn{2}{|c|}{ Overflow } & \multicolumn{2}{|c|}{ Underdrain } & \multicolumn{2}{|c|}{ Overflow } & \multicolumn{2}{|c|}{ Underdrain } & \multicolumn{2}{|c|}{ Overflow } \\
\hline & Influent $_{\text {Adj }}$ & Effluent & Influent $_{\text {Adj }}$ & Effluent & Influent $_{\text {Adj }}$ & Effluent & Influent $_{\text {Adj }}$ & Effluent & Influent $_{\text {Adj }}$ & Effluent & Influent $_{\text {Adj }}$ & Effluent \\
\hline \multicolumn{13}{|c|}{ Dissolved phosphorus, in grams } \\
\hline $\mathrm{n}$ & 33 & 33 & 10 & 10 & 19 & 19 & 22 & 21 & 37 & 37 & 17 & 17 \\
\hline Min & 0.06 & 0.06 & 0.07 & 0.16 & 0.01 & 0.02 & 0.04 & 0.06 & 0.02 & 0.07 & 0.02 & 0.04 \\
\hline $\operatorname{Max}$ & 2.78 & 2.89 & 1.85 & 2.26 & 1.71 & 0.94 & 0.77 & 1.13 & 2.29 & 3.13 & 0.61 & 0.61 \\
\hline Median & 0.26 & 0.39 & 0.25 & 0.46 & 0.08 & 0.14 & 0.16 & 0.25 & 0.14 & 0.36 & 0.09 & 0.33 \\
\hline Mean & 0.45 & 0.69 & 0.51 & 0.68 & 0.21 & 0.21 & 0.23 & 0.36 & 0.45 & 0.61 & 0.17 & 0.32 \\
\hline Std dev & 0.54 & 0.70 & 0.52 & 0.63 & 0.38 & 0.21 & 0.19 & 0.29 & 0.59 & 0.70 & 0.16 & 0.17 \\
\hline Sum & 15 & 23 & 5 & 7 & 4 & 4 & 5 & 8 & 17 & 23 & 3 & 5 \\
\hline $\mathrm{RE}$ & NA & $-52 \%$ & NA & $-34 \%$ & NA & $2 \%$ & NA & $-56 \%$ & NA & $-37 \%$ & NA & $-90 \%$ \\
\hline$p$ value & NA & $<0.01(+)$ & NA & $<0.01(+)$ & NA & 0.88 & NA & $<0.01(+)$ & NA & $<0.01(+)$ & NA & $<0.01(+)$ \\
\hline \multicolumn{13}{|c|}{ Chloride, in grams } \\
\hline $\mathrm{n}$ & 30 & 30 & 10 & 10 & 15 & 15 & 19 & 19 & 32 & 32 & 15 & 15 \\
\hline Min & 2.5 & 3.1 & 5.0 & 4.9 & 1.3 & 2.4 & 4.2 & 6.1 & 1.9 & 5.4 & 2.3 & 2.3 \\
\hline Max & 573.2 & 442.4 & 35.0 & 44.8 & 215.9 & 147.5 & 131.0 & 149.4 & 380.9 & 207.3 & 52.4 & 60.9 \\
\hline Median & 14.3 & 20.1 & 14.2 & 17.4 & 5.9 & 22.0 & 8.7 & 12.1 & 15.6 & 18.9 & 7.9 & 10.5 \\
\hline Mean & 57.8 & 60.7 & 16.2 & 20.6 & 42.6 & 36.1 & 21.7 & 24.4 & 40.4 & 39.1 & 11.4 & 14.8 \\
\hline Std dev & 125.8 & 97.4 & 8.8 & 11.7 & 69.4 & 42.8 & 31.6 & 32.9 & 77.8 & 50.5 & 12.1 & 15.5 \\
\hline Sum & 1,734 & 1,821 & 162 & 206 & 638 & 541 & 412 & 463 & 1293 & 1251 & 172 & 222 \\
\hline $\mathrm{RE}$ & NA & $-5 \%$ & NA & $-27 \%$ & NA & $15 \%$ & NA & $-12 \%$ & NA & $3 \%$ & NA & $-30 \%$ \\
\hline$p$ value & NA & $<0.01(+)$ & NA & $0.04(+)$ & NA & $0.03(+)$ & NA & $0.02(+)$ & NA & $<0.01(+)$ & NA & $<0.01(+)$ \\
\hline \multicolumn{13}{|c|}{ Escherichia coli (E. coli), in colonies } \\
\hline $\mathrm{n}$ & 26 & 26 & 6 & 6 & 15 & 15 & 19 & 19 & 29 & 29 & 14 & 14 \\
\hline Min & 197,820 & 14,583 & 109,007 & 410,311 & 4,814 & 3,398 & 113,840 & 8,637 & 3,610 & 2,548 & 140,695 & 10,477 \\
\hline $\operatorname{Max}$ & $2.29 \times 10^{9}$ & $3.18 \times 10^{9}$ & $5.78 \times 10^{9}$ & $3.36 \times 10^{9}$ & $2.83 \times 10^{8}$ & $9.79 \times 10^{7}$ & $7.87 \times 10^{8}$ & $4.86 \times 10^{8}$ & $9.40 \times 10^{9}$ & $6.60 \times 10^{9}$ & $9.33 \times 10^{8}$ & $6.08 \times 10^{8}$ \\
\hline Median & $8.36 \times 10^{7}$ & $4.00 \times 10^{7}$ & $4.28 \times 10^{8}$ & $6.22 \times 10^{7}$ & $1.03 \times 10^{7}$ & $1.68 \times 10^{5}$ & $4.77 \times 10^{7}$ & $2.58 \times 10^{7}$ & $5.50 \times 10^{7}$ & $2.46 \times 10^{7}$ & $7.18 \times 10^{7}$ & $2.82 \times 10^{7}$ \\
\hline Mean & $3.76 \times 10^{8}$ & $3.56 \times 10^{8}$ & $1.58 \times 10^{9}$ & $6.28 \times 10^{8}$ & $6.28 \times 10^{7}$ & $1.14 \times 10^{7}$ & $1.60 \times 10^{8}$ & $1.08 \times 10^{8}$ & $8.27 \times 10^{8}$ & $4.33 \times 10^{8}$ & $1.98 \times 10^{8}$ & $1.43 \times 10^{8}$ \\
\hline Std dev & $5.89 \times 10^{8}$ & $7.87 \times 10^{8}$ & $2.11 \times 10^{9}$ & $1.22 \times 10^{9}$ & $9.49 \times 10^{7}$ & $2.50 \times 10^{7}$ & $2.33 \times 10^{8}$ & $1.54 \times 10^{8}$ & $2.13 \times 10^{9}$ & $1.31 \times 10^{9}$ & $2.84 \times 10^{8}$ & $1.92 \times 10^{8}$ \\
\hline Sum & $9.8 \times 10^{9}$ & $9.2 \times 10^{9}$ & $9.5 \times 10^{9}$ & $3.8 \times 10^{9}$ & $9.4 \times 10^{8}$ & $1.7 \times 10^{8}$ & $3.0 \times 10^{9}$ & $2.1 \times 10^{9}$ & $2.4 \times 10^{10}$ & $1.3 \times 10^{10}$ & $2.8 \times 10^{9}$ & $2.0 \times 10^{9}$ \\
\hline $\mathrm{RE}$ & NA & $5 \%$ & NA & $60 \%$ & NA & $82 \%$ & NA & $32 \%$ & NA & $48 \%$ & NA & $28 \%$ \\
\hline$p$ value & NA & $0.04(-)$ & NA & 0.10 & NA & $<0.01(-)$ & NA & $<0.01(-)$ & NA & $<0.01(-)$ & NA & 0.11 \\
\hline
\end{tabular}


Table 10. Summary statistics of pollutant loads with calculated removal efficiencies and statistical significance at the underdrain and overflow monitoring points in the porous asphalt, pervious concrete, and permeable interlocking pavers test plots._-Continued

[PA, porous asphalt; PC, pervious concrete; PIP, permeable interlocking pavers; Influent ${ }_{\text {Adj }}$, adjusted influent load; $n$, number of observations; Min, minimum; Max, maximum; Std dev, standard deviation; $\mathrm{RE}$, removal efficiency; NA, not applicable; \%, percent; negative RE values indicate pollutant export; values in bold indicate a significant increase (+) or decrease (-) in load at the 95 percent confidence level]

\begin{tabular}{|c|c|c|c|c|c|c|c|c|c|c|c|c|}
\hline \multirow{3}{*}{ Statistic } & \multicolumn{4}{|c|}{ PA } & \multicolumn{4}{|c|}{ PC } & \multicolumn{4}{|c|}{ PIP } \\
\hline & \multicolumn{2}{|c|}{ Underdrain } & \multicolumn{2}{|c|}{ Overflow } & \multicolumn{2}{|c|}{ Underdrain } & \multicolumn{2}{|c|}{ Overflow } & \multicolumn{2}{|c|}{ Underdrain } & \multicolumn{2}{|c|}{ Overflow } \\
\hline & Influent $_{\text {Adj }}$ & Effluent & Influent $_{\text {Adj }}$ & Effluent & Influent $_{\text {Adj }}$ & Effluent & Influent $_{\text {Adj }}$ & Effluent & Influent $_{\text {Adj }}$ & Effluent & Influent $_{\text {Adj }}$ & Effluent \\
\hline \multicolumn{13}{|c|}{ Enterococci, in colonies } \\
\hline $\mathrm{n}$ & 26 & 26 & 6 & 6 & 15 & 15 & 19 & 19 & 29 & 29 & 14 & 14 \\
\hline Min & $1.47 \times 10^{6}$ & 57 & $1.91 \times 10^{6}$ & $1.70 \times 10^{6}$ & 388,000 & 47,600 & 654,000 & 292,000 & 361,000 & 107,000 & $1.05 \times 10^{6}$ & 9 \\
\hline Max & $1.44 \times 10^{10}$ & $7.09 \times 10^{9}$ & $1.64 \times 10^{10}$ & $2.53 \times 10^{10}$ & $2.39 \times 10^{9}$ & $4.42 \times 10^{8}$ & $8.48 \times 10^{9}$ & $8.42 \times 10^{9}$ & $1.95 \times 10^{10}$ & $1.59 \times 10^{10}$ & $2.65 \times 10^{9}$ & $1.85 \times 10^{9}$ \\
\hline Median & $2.25 \times 10^{8}$ & $1.43 \times 10^{8}$ & $8.46 \times 10^{8}$ & $3.62 \times 10^{8}$ & $2.61 \times 10^{7}$ & $1.28 \times 10^{7}$ & $1.03 \times 10^{8}$ & $1.74 \times 10^{8}$ & $1.04 \times 10^{8}$ & $1.11 \times 10^{8}$ & $1.35 \times 10^{8}$ & $1.57 \times 10^{8}$ \\
\hline Mean & $1.14 \times 10^{9}$ & $7.74 \times 10^{8}$ & $3.31 \times 10^{9}$ & $4.56 \times 10^{9}$ & $2.11 \times 10^{8}$ & $4.72 \times 10^{7}$ & $6.14 \times 10^{8}$ & $6.17 \times 10^{8}$ & $1.19 \times 10^{9}$ & $8.17 \times 10^{8}$ & $6.27 \times 10^{8}$ & $4.69 \times 10^{8}$ \\
\hline Std dev & $2.94 \times 10^{9}$ & $1.79 \times 10^{9}$ & $5.85 \times 10^{9}$ & $9.29 \times 10^{9}$ & $5.86 \times 10^{8}$ & $1.07 \times 10^{8}$ & $1.87 \times 10^{9}$ & $1.85 \times 10^{9}$ & $3.59 \times 10^{9}$ & $2.88 \times 10^{9}$ & $9.37 \times 10^{8}$ & $6.07 \times 10^{8}$ \\
\hline Sum & $3.0 \times 10^{10}$ & $2.0 \times 10^{10}$ & $2.0 \times 10^{10}$ & $2.7 \times 10^{10}$ & $3.2 \times 10^{9}$ & $7.1 \times 10^{8}$ & $1.2 \times 10^{10}$ & $1.2 \times 10^{10}$ & $3.4 \times 10^{10}$ & $2.4 \times 10^{10}$ & $8.8 \times 10^{9}$ & $6.6 \times 10^{9}$ \\
\hline $\mathrm{RE}$ & NA & $32 \%$ & NA & $-38 \%$ & NA & $78 \%$ & NA & $<1 \%$ & NA & $31 \%$ & NA & $25 \%$ \\
\hline$p$ value & NA & 0.06 & NA & 0.10 & NA & $<0.01(-)$ & NA & 0.43 & NA & $0.05(-)$ & NA & 0.46 \\
\hline
\end{tabular}




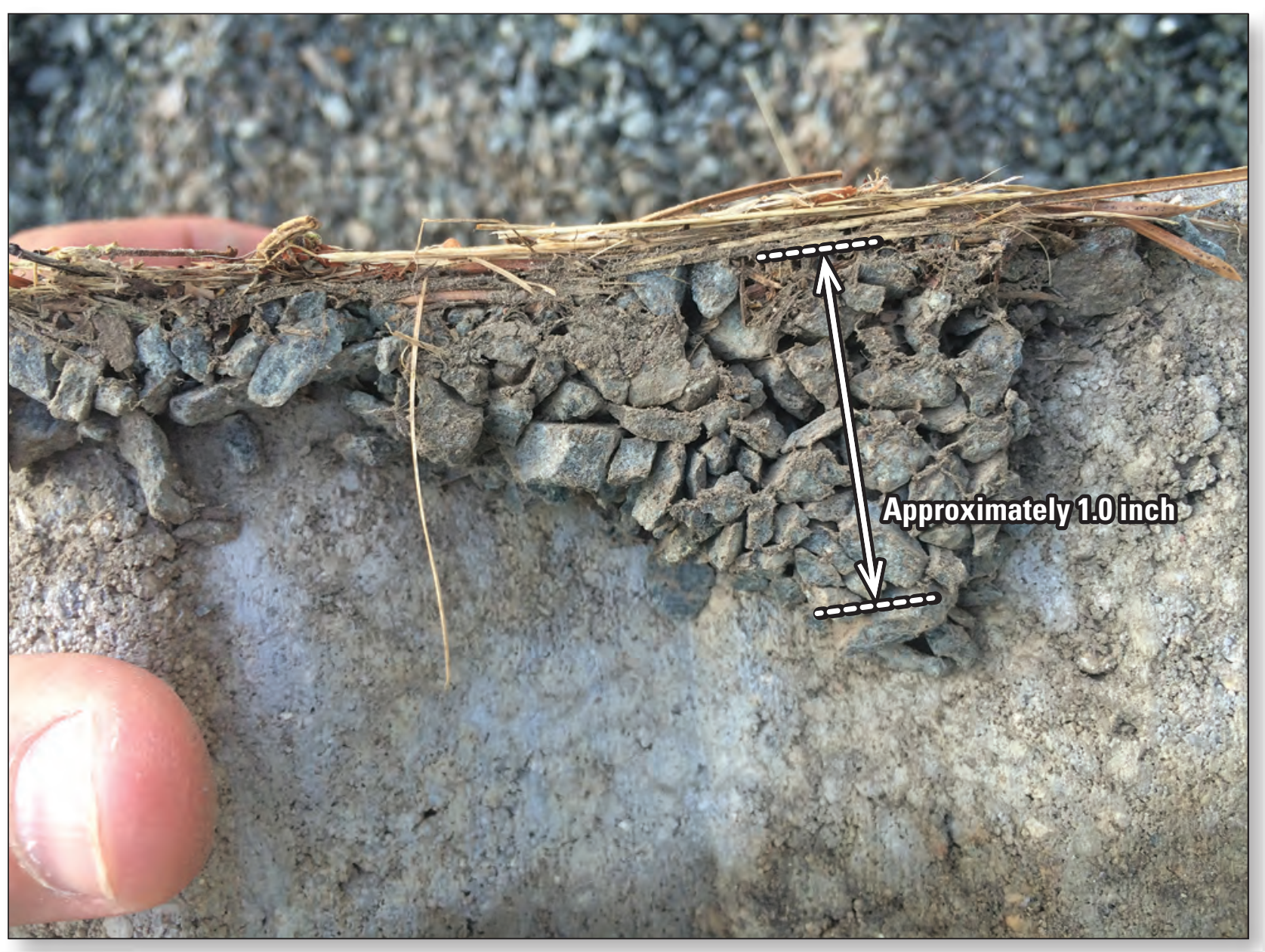

Figure 14. Profile of sediment captured into the aggregate used between the joints of the permeable interlocking pavers test surface.

Export of dissolved phosphorus ranged from 37 to 52 percent in the underdrain and 34 to 90 percent in the overflow (table 10). Only the PC underdrain indicated slight reductions in dissolved phosphorus but was not statistically significant $(p$ value $=0.88)$. Using a similar study design, Brown and Borst (2015b) also determined that the removal of dissolved phosphorus varied among permeable pavements. Reductions in dissolved phosphorus were thought to be associated with the precipitation of metal ions as $\mathrm{pH}$ increased in PA; however, PC and PIP were sources of dissolved phosphorus with significantly larger amounts in effluent than influent.

The inability to reduce total and dissolved phosphorus could be due to an already low influent concentration such that further reduction would require physical processes beyond those in permeable pavement. Winston and others (2016a) made similar conclusions after observing no change in median concentrations of orthophosphate between influent from an asphalt parking lot and effluent from two PIP retrofits. The idea of an "irreducible" concentration, as suggested by Strecker and others (2001), might be valid if no change was detected in the underdrain or overflow. Increases in concentration and load indicate otherwise. Removal of dissolved-phase material from suspension may have been offset by contributions from new sources such as atmospheric deposition and organic detritus from nearby vegetation (fig. 15). Application of fertilizers from adjoining landscapes, as suggested by Bean and others (2007), also may have contributed to higher effluent concentrations; however, this circumstance is unlikely because a county-wide ban of phosphorus in lawn fertilizers was enacted in 2005. 


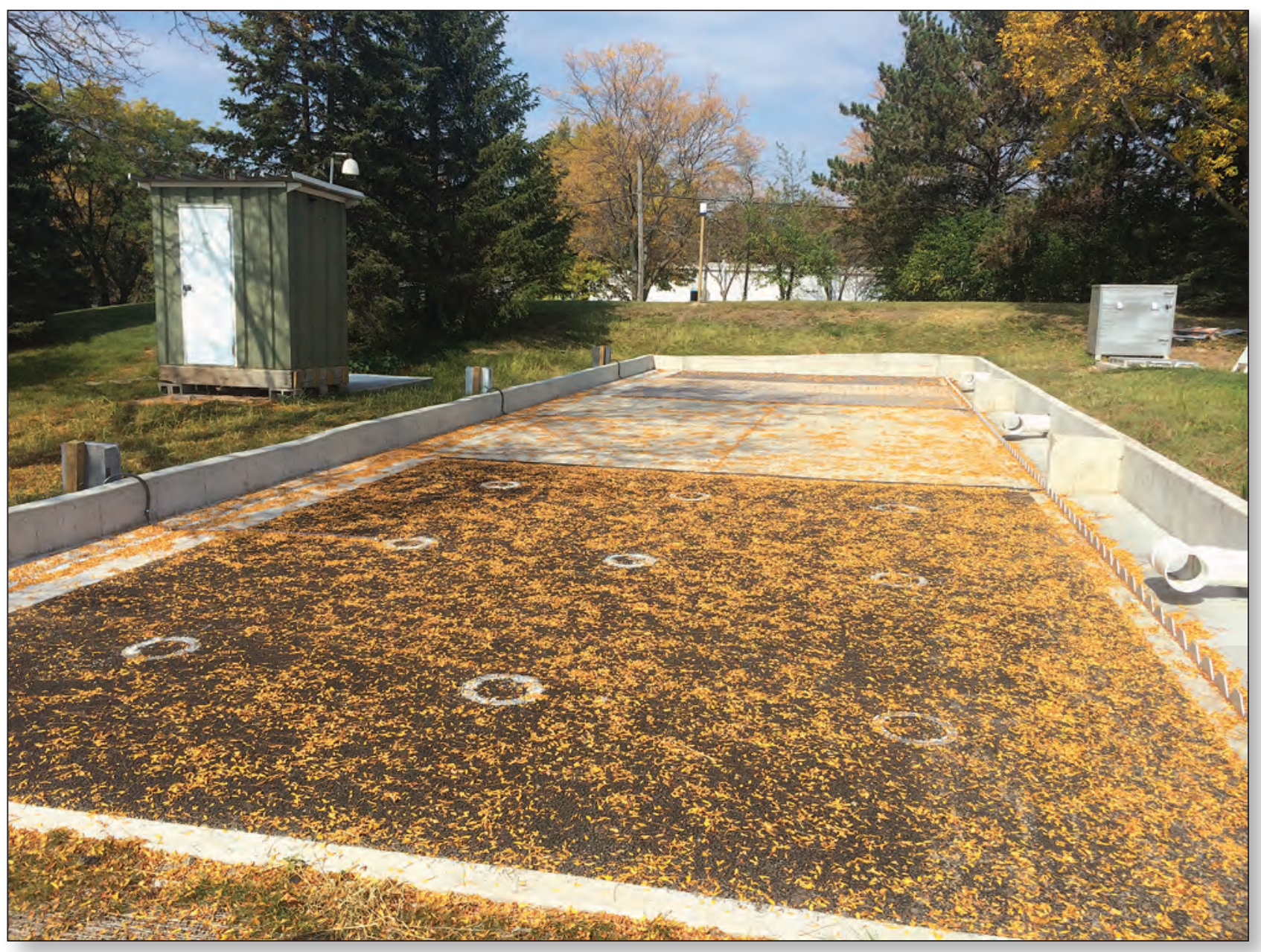

Figure 15. Unmonitored sources of nutrients, seen here as the deposition of leaves from nearby trees, could potentially lead to effluent concentrations of dissolved phosphorus that are higher than the influent.

\section{Chloride}

All three permeable pavements were unable to reduce the load of chloride in runoff from the parking lot. Although removal efficiencies in the PC and PIP underdrains indicated slight reductions in chloride, when the Wilcoxon signedrank test for paired samples (Helsel and Hirsch, 2002) was used, significant increases were observed in all underdrains and overflows ( $p$ less than 0.05) (table 10). The discrepancy between statistical comparison and computation of removal efficiencies can be explained by closer examination of discrete runoff events in Selbig (2018). A majority of the chloride load influent to PA, PC, and PIP was from the first four spring runoff events in late March and early April 2015, a result of elevated concentrations from prior winter deicing application. The adjusted influent load of chloride for these four events accounted for 77, 87, and 64 percent of the cumulative load in the PA, PC, and PIP test plots, respectively, during the 24-month study period. Underdrain effluent chloride load for these events were also some of the highest observed but were lower than the corresponding influent load resulting in a net reduction in load. These four events, therefore, substantially influenced resulting removal efficiencies, whereas the nonparametric statistical evaluation was not affected by skew. These results indicate that each permeable surface had some temporary storage of chloride after initial dosage. Effluent loads gradually declined throughout the year as chloride was slowly flushed from the permeable pavements until new sources were applied the following winter. Elevated levels of chloride were again observed in early spring 2016 (Selbig, 2018); however, because of an insufficient number of samples, few conclusions could be made. This cycle of elevated chloride concentrations and load, which is associated with early snowmelt and spring runoff and is followed by gradual dilution from subsequent storms, is expected to repeat if road salt is continued to be used as a deicing agent.

The export of chloride from permeable pavement is consistent with results from some previous studies (Roseen and others, 2012; Winston and others, 2016b) but is inconsistent with others (Drake and others, 2014b). Winston and others (2016a) observed a significant reduction in chloride load in one application of PIP but no change in a smaller application. 
Differences were attributed to improved exfiltration in the large application as well as a higher rate of winter salting in the small application. Drake and others (2014b) reported significant reductions of chloride and sodium loads in monitored permeable pavement systems but acknowledged that the reduction was primarily through exfiltration into native soils with little retention by the permeable pavement. Without an impermeable liner, permeable pavement provides little treatment for dissolved ions and may pose a risk to groundwater resources through exfiltration of chloride-enriched runoff rather than be sequestered in the permeable surface or aggregate base (Pitt and others, 1999).

\section{Bacteria}

E. coli and Enterococci loads were significantly reduced as runoff filtered through each permeable pavement (table 10). Compared to parking lot runoff, $\mathrm{PC}$ had the largest reduction followed by PIP and PA. In many cases, PC was able to reduce E. coli concentrations below detection levels (table 6) producing negligible load in the underdrain effluent. Loads of $E$. coli measured in the overflow effluent were also reduced but at a slightly higher level of significance than the underdrain $(p$ value less than 0.10 ). The reason why PC was better able to reduce bacterial pathogens than PA or PIP is unclear. Periodic measurements indicated that $\mathrm{pH}$ in the $\mathrm{PC}$ underdrain effluent ranged from 10 to 11 . The $\mathrm{pH}$ values were higher for $\mathrm{PC}$ than for PA and PIP, which were more neutral. The differences in $\mathrm{pH}$ were unexpected because geochemical buffering reactions should have occurred in all three permeable pavements given the similarities in aggregate mineralogy (limestone and dolomite). Cementitious materials used as ingredients in PC but not in PA or PIP, such as fly ash, may have elevated $\mathrm{pH}$ to levels unfavorable for bacteria proliferation, although previous research indicates that Enterococcus bacteria possibly can flourish in alkaline environments (Wahyuni, 2015). Biodegradation processes in permeable pavement, as seen from oxygen depletion and carbon dioxide production, resulted in more than 90 percent removal of E. coli and fecal Streptococci (Tota-Maharaj and Scholz, 2010). The presence of an underdrain would have likely prevented anoxic conditions as well as supported bacterial growth by maintaining a wet, nutrient rich environment that undergoes episodic flushing (Hathaway and others, 2009; Mohanty and others, 2013).

Regardless of the unit process responsible for bacteria reduction, a paucity of available data makes comparison difficult because few studies have documented the removal of fecal indicator bacteria in permeable pavements. In a review of current research on low-impact development practices, Dietz (2007) noted that information on bacteria and virus removal by permeable pavement is lacking. The majority of previous research has been directed more towards regulated pollutants such as TSS and total phosphorus.

\section{Combined Effect of Underdrain and Overflow}

The removal efficiency of each permeable pavement when loads measured in the underdrain and in the overflow effluent are combined is listed in table 11. Pollutant removal efficiencies are modest when the load bypassing as overflow is considered part of the overall performance of a permeable pavement system. The development of preferential pathways across each permeable surface reduced the effective area to maximize treatment. Distribution of runoff across the permeable surface was only possible for precipitation events with high intensity. This distinction is important considering that pollutant reduction credits prescribed by the Wisconsin technical standard for permeable pavement (Wisconsin Department of Natural Resources, 2016) address only the water-quality treatment of runoff that filters through the permeable surface. Techniques used to spread runoff across the permeable surface as part of this study are unlikely to be replicated in real-world applications, increasing the chance of preferential pathways. Therefore, when determining performance of permeable pavement as a water-quality treatment option, the proportion of pollutants transferred by overflow also should be considered.

\section{Comparison of Temperature}

The temperature of urban runoff is affected by the amount of heat that is absorbed from impervious surfaces such as roofs, driveways, streets, and parking lots (Oke, 1982; Roa-Espinosa and others, 2003). The large thermal inertia and dark surface of traditional asphalt, in particular, can contribute to the heat island effect through absorption of sensible heat and lack of evaporative cooling (Qin, 2015). Solutions to heat absorption include changing pavement materials or design to raise the solar reflectance, enhance evaporation, or harness the heat for other uses. Permeable pavement could mitigate heat absorption because water may be stored in the aggregate reservoir for evaporative cooling (Qin, 2015).

Because permeable pavement is porous, it also may be considered a beneficial technology when temperatures are below freezing, even during periods of prolonged frost penetration. Temperatures below permeable pavement responded more rapidly to changes in ambient air temperature compared to a nearby reference location (Roseen and others, 2012). This response was attributed to infiltration of meltwater. Although temperatures below permeable pavement would reach freezing sooner and deeper than the reference, the pores remained open. 
Table 11. Removal efficiency of each permeable pavement when loads measured in the underdrain and overflow effluent were combined.

[Influent ${ }_{\text {Adj }}$, adjusted influent load; values are in grams except for E. coli and enterococci, which are in colonies]

\begin{tabular}{|c|c|c|c|c|c|c|c|c|c|}
\hline \multirow{2}{*}{ Pollutant } & \multicolumn{3}{|c|}{ Influent $_{\text {Adj }}$} & \multicolumn{3}{|c|}{ Effluent } & \multicolumn{3}{|c|}{ Percent change } \\
\hline & Underdrain & Overflow & Total & Underdrain & Overflow & Total & Underdrain & Overflow & Total \\
\hline \multicolumn{10}{|c|}{ Porous asphalt } \\
\hline Total suspended solids & 39,923 & 4,229 & 44,151 & 14,096 & 2,741 & 16,837 & -65 & -35 & -62 \\
\hline Suspended sediment & 43,054 & 4,768 & 47,821 & 9,699 & 4,204 & 13,902 & -77 & -12 & -71 \\
\hline Total phosphorus & 64 & 11 & 74 & 49 & 12 & 61 & -23 & 11 & -18 \\
\hline Dissolved phosphorus & 15 & 5 & 20 & 23 & 7 & 30 & 52 & 34 & 47 \\
\hline Escherichia coli & $9.8 \times 10^{9}$ & $9.5 \times 10^{9}$ & $1.9 \times 10^{10}$ & $9.2 \times 10^{9}$ & $3.8 \times 10^{9}$ & $1.3 \times 10^{10}$ & -5 & -60 & -32 \\
\hline Enterococci & $3.0 \times 10^{10}$ & $2.0 \times 10^{10}$ & $4.9 \times 10^{10}$ & $2.0 \times 10^{10}$ & $2.7 \times 10^{10}$ & $4.7 \times 10^{10}$ & -32 & 38 & -4 \\
\hline \multicolumn{10}{|c|}{ Pervious concrete } \\
\hline Total suspended solids & 11,903 & 14,826 & 26,729 & 2,375 & 8,637 & 11,012 & -80 & -42 & -59 \\
\hline Suspended sediment & 10,834 & 15,748 & 26,582 & 1,998 & 11,264 & 13,263 & -82 & -28 & -50 \\
\hline Total phosphorus & 17 & 23 & 40 & 8 & 23 & 31 & -51 & -1 & -23 \\
\hline Chloride & 638 & 412 & 1,050 & 541 & 463 & 1,005 & -15 & 12 & -4 \\
\hline Escherichia coli & $9.4 \times 10^{8}$ & $3.0 \times 10^{9}$ & $4.0 \times 10^{9}$ & $1.7 \times 10^{8}$ & $2.1 \times 10^{9}$ & $2.2 \times 10^{9}$ & -82 & -32 & -44 \\
\hline Enterococci & $3.2 \times 10^{9}$ & $1.2 \times 10^{10}$ & $1.5 \times 10^{10}$ & $7.1 \times 10^{8}$ & $1.2 \times 10^{10}$ & $1.2 \times 10^{10}$ & -78 & 0 & -16 \\
\hline \multicolumn{10}{|c|}{ Permeable interlocking pavers } \\
\hline Total suspended solids & 29,039 & 9,050 & 38,089 & 8,942 & 4,560 & 13,502 & -69 & -50 & -65 \\
\hline Suspended sediment & 31,773 & 8,105 & 39,878 & 11,830 & 5,709 & 17,539 & -63 & -30 & -56 \\
\hline Total phosphorus & 52 & 12 & 65 & 45 & 12 & 58 & -14 & 2 & -11 \\
\hline Dissolved phosphorus & 17 & 3 & 19 & 23 & 5 & 28 & 37 & 90 & 44 \\
\hline Chloride & 1,293 & 172 & 1,465 & 1,251 & 222 & 1,474 & -3 & 30 & 1 \\
\hline Escherichia coli & $2.4 \times 10^{10}$ & $2.8 \times 10^{9}$ & $2.7 \times 10^{10}$ & $1.3 \times 10^{10}$ & $2.0 \times 10^{9}$ & $1.5 \times 10^{10}$ & -48 & -28 & -46 \\
\hline Enterococci & $3.4 \times 10^{10}$ & $8.8 \times 10^{9}$ & $4.3 \times 10^{10}$ & $2.4 \times 10^{10}$ & $6.6 \times 10^{9}$ & $3 \times 10^{10}$ & -31 & -25 & -30 \\
\hline
\end{tabular}




\section{Summer Cooling}

A typical response to changing atmospheric conditions during summer is presented in figure 16 that shows a single central profile of each permeable pavement at 0,6 , and 12 inches into the aggregate base, herein referred to as the top, middle, and bottom layers. Parking lot runoff discharged to the permeable pavement test plots and corresponding temperature also are shown in figure 16. Because of its location, the parking lot temperature sensor represents air temperature during dry weather and water temperature during periods of runoff.

In the summer, temperatures in the top layer of each test plot (just below the permeable surface) typically rise and fall with ambient air temperature prior to a runoff event. The rate of change in PA was much faster than PC or PIP, lagging air temperature by less than 10 minutes. As such, maximum temperatures in the top layer of PA on June 10, 2015, were only a few degrees cooler than the corresponding maximum air temperature. The larger void space and dark color of PA was better able to absorb and transfer heat from the surface to the bottom layer. PC and PIP, both lighter in color with smaller void space, were slower to adjust to changes in air temperature with approximately a 30- and 60-minute lag time, respectively. Unlike PA, PC and PIP maximum temperatures in the top layer on June 10,2015 , were approximately $10{ }^{\circ} \mathrm{C}$ cooler than the corresponding maximum air temperature. The rate of temperature increase slowed with increasing depth for all permeable pavements. As air temperature decreased, temperatures below each permeable surface also decreased. The PA, PC, and PIP surfaces, along with underlying aggregate, were able to retain some of the heat absorbed throughout the day allowing for a slower rate of cooling during the evening and nighttime hours. This diurnal fluctuation was repeated until the onset of runoff on June 11,2015, which was indicated by the presence of influent discharge. Despite cooler air temperatures prior to the onset of precipitation, the surface temperature of the parking lot remained elevated, causing slight increases in water temperature with each spike in discharge. As runoff filtered through PIP, a sudden change in temperature was observed across all depths as all three sensors converged to approximately the same value. The rapid response to infiltrating water was less pronounced in the PA and PC test plots, especially at the middle and bottom layers. This result could have been due to an insufficient volume of water influent to PA and PC whereby preferential pathways diverted most of the runoff to sections away from the temperature sensors shown in figure 16. This result could also have been due to reduced infiltration rates in the represented area that would have delayed the response of temperature change because of infiltrating runoff. A review of temperature response to runoff infiltrating near the front, rather than the center, of the PA and PC surfaces supports this assertion by indicating a convergence in PA similar to PIP, but not PC. Regardless, all three surfaces indicated a continued decline in temperature as the storm progressed, with the warmest layers at the bottom and the coolest near the surface. Despite the gradation in temperature below each permeable surface, all depths retained a higher temperature than that of parking lot runoff for the majority of the storm event. Only near the end of the storm does the top layer begin to converge with the temperature of influent runoff.

Permeable pavement was unable to cool runoff to a temperature below the temperature that was measured from the parking lot. The lack of cooling in each test plot is illustrated in figure 17 by comparing water temperatures in underdrain effluent to that of parking lot influent. During the period of runoff, the mean temperature of runoff from the parking lot was $17.5^{\circ} \mathrm{C}$. This mean temperature was more than $1^{\circ} \mathrm{C}$ cooler than the mean effluent temperatures of 18.7, 18.8, and 19.5 for the PIP, PA, and PC test plots, respectively. Further comparison of influent and effluent temperatures with the Kruskal-Wallis $k$ sample test (Helsel and Hirsch, 2002) and with followup pairwise comparisons using Dunn's test with Bonferroni adjustment indicated that influent temperatures were significantly lower than all underdrain effluent temperatures. Results also confirmed the effluent temperature from PC was higher than PA and PIP; PA and PIP were not different from one another.

Runoff filtering through permeable pavement may not be appreciably cooled during summer (figs. 16-17). The temperature of runoff from the parking lot seems to be mostly controlled by ambient air temperature with only slight increases in temperature after daytime heating. The absorption of heat at depth by each permeable pavement, although initially reduced by the onset of runoff, was enough to sustain temperatures above what were measured from the parking lot. Circumstances, however, could cause permeable pavement to provide cooling below ambient air temperature, such as runoff events that occur during midday, when air temperature is much warmer than the bottom layer of permeable pavement.

The lack of thermal mitigation in PA, PC, and PIP is somewhat inconsistent to other stormwater control measures that have been determined to buffer thermal impacts bypassing water through cooler subsurface media. Reduced temperatures were observed by Wardynski and others (2013) in effluent from three configurations of PIP in North Carolina that varied proportionally to rates of runoff reduction. The difference was attributed to an internal water storage that increased volume reduction through exfiltration. The PIP cell that did not have internal water storage had median stormwater effluent temperatures that exceeded the critical trout threshold temperature of $21^{\circ} \mathrm{C}$. Although these systems could provide some thermal mitigation between top and bottom profiles of PIP, the thermal mitigation was primarily done through volume reduction. Permeable pavements that incorporate an impermeable liner at the base, as in this study, are not designed for volume control and, therefore, may not have the same thermal benefits. 

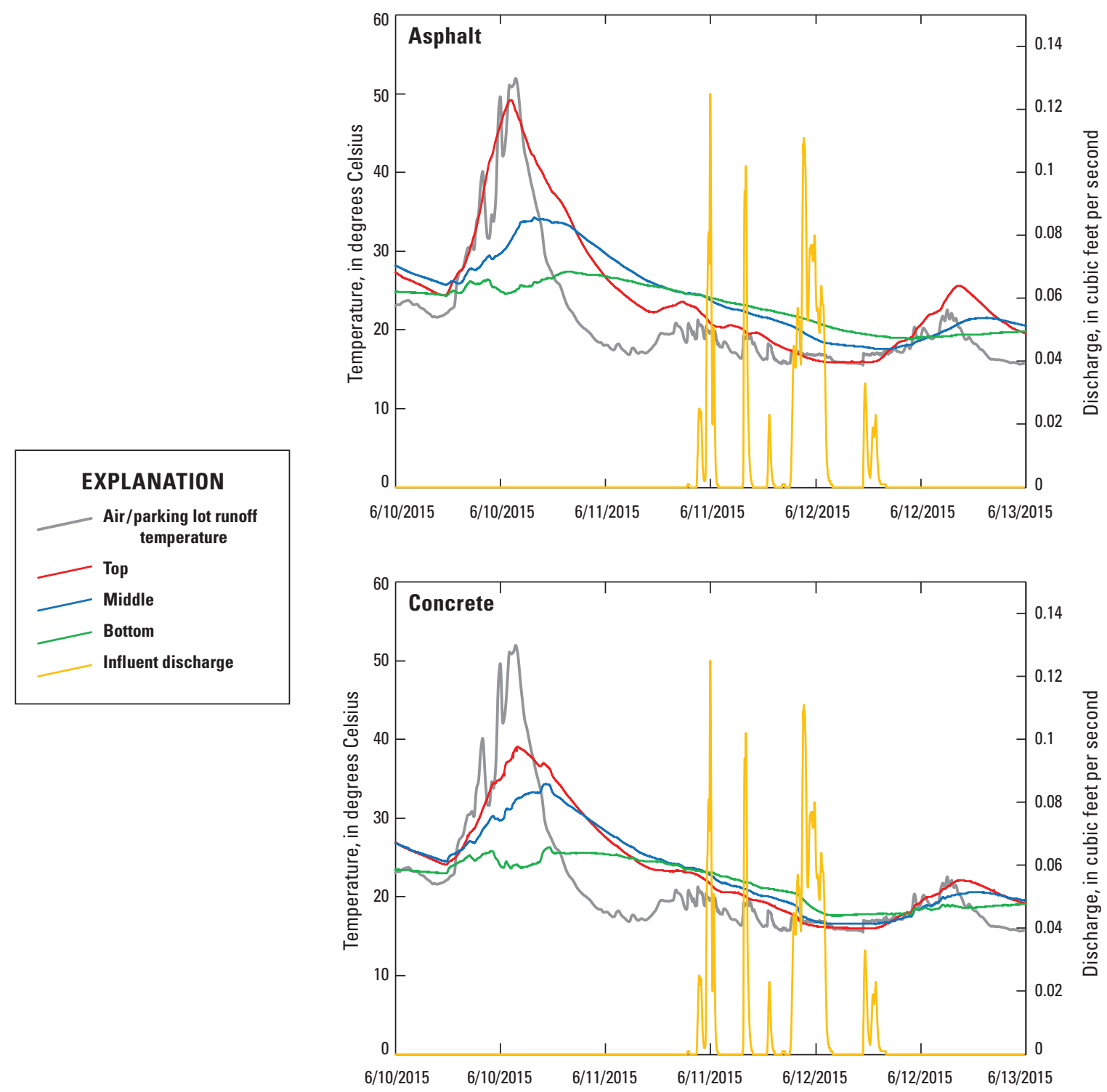

Figure 16. Typical response to changing air temperatures at 0 (top), 6 (middle), and 12 (bottom) inches below the porous asphalt, pervious concrete, and permeable interlocking pavers surfaces during summer. Air temperature becomes parking lot runoff temperature during periods of influent discharge.

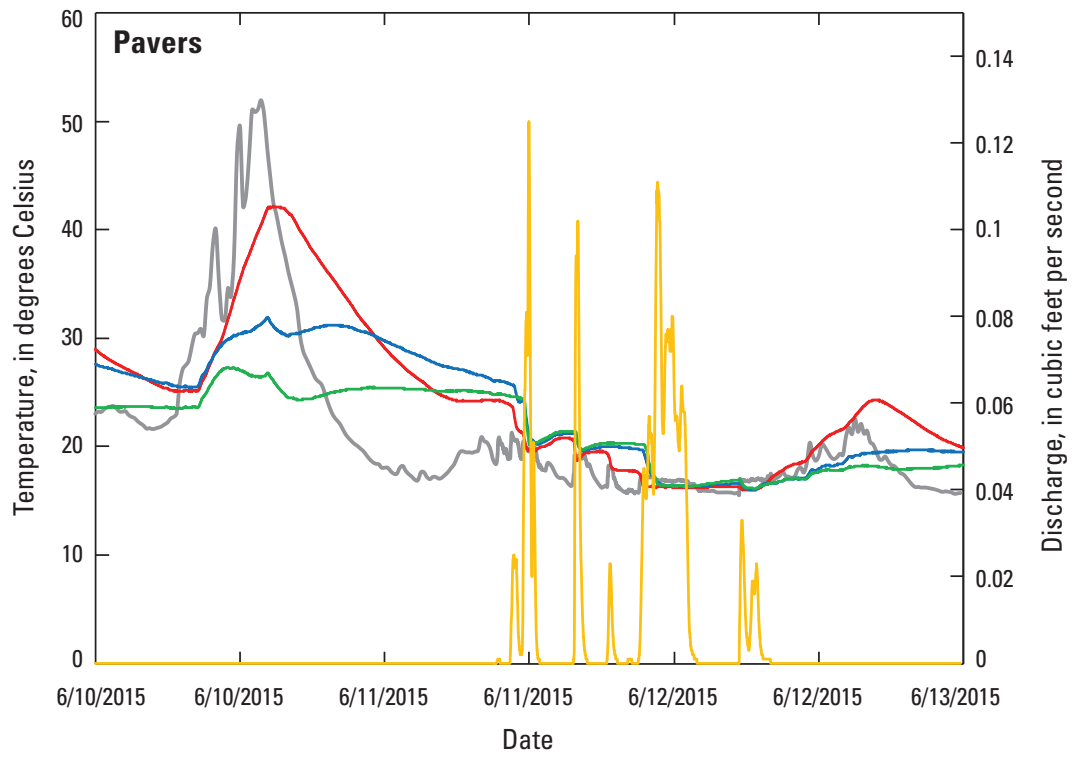




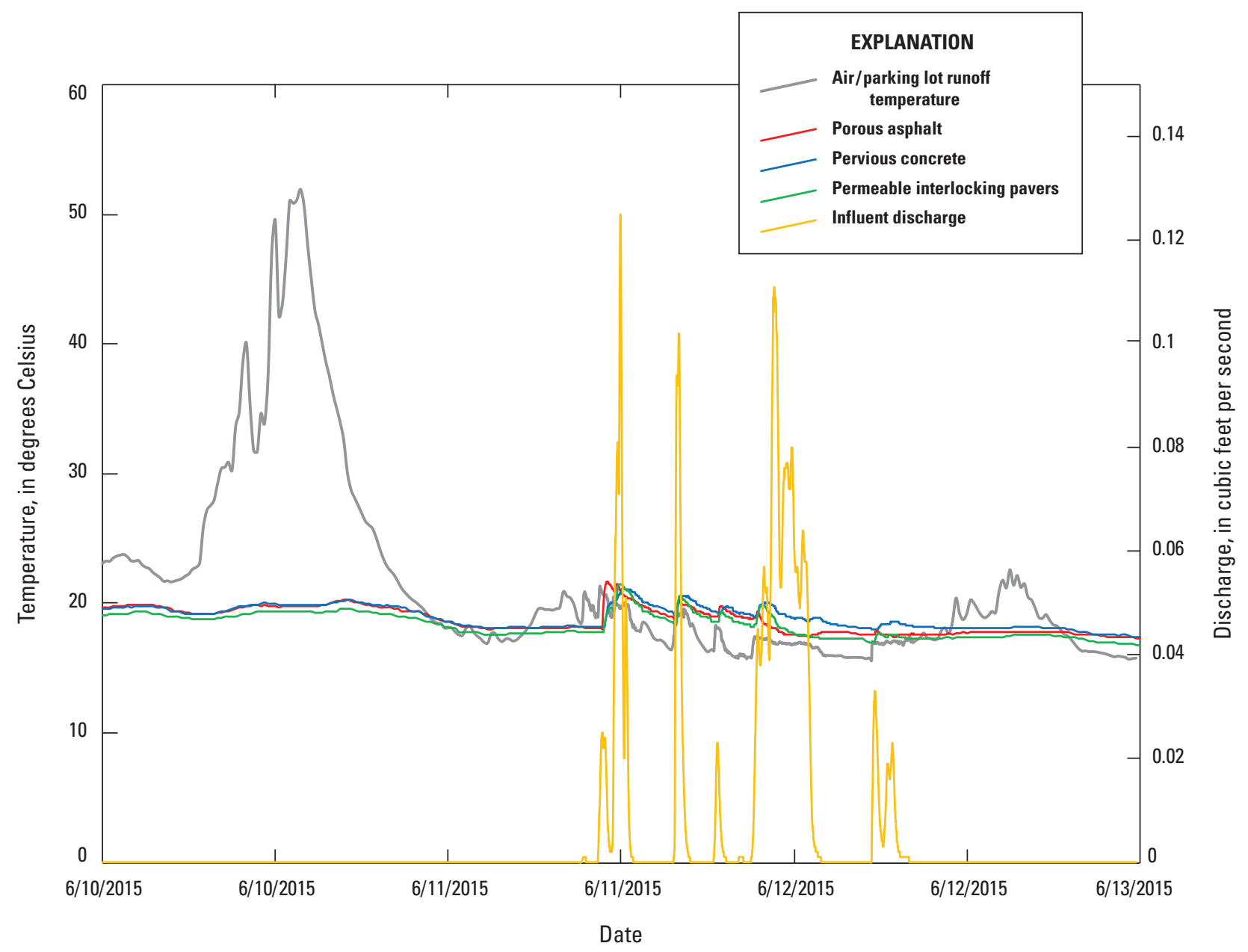

Figure 17. Influence of permeable pavement type on water temperature measured in the underdrains of the porous asphalt, pervious concrete, and permeable interlocking pavers test plots during a typical summer storm in June 2015. Air temperature becomes parking lot runoff temperature during periods of influent discharge.

\section{Winter Warming}

Similar to summer, temperatures just below each permeable surface closely followed diurnal changes in air temperature during winter, with rate and magnitude responding much faster in PA than in PC or PIP (fig. 18). The lag to peak behind air temperature for PA was approximately 45 minutes compared to 60 and 90 minutes for PIP and PC, respectively. Despite the rapid changes in temperature observed in the top layers, winter lag for all test plots was much slower than in summer. This result, in part, may be due to frozen pore openings in the permeable surface, thereby reducing exposure to atmospheric conditions. Temperatures at increasing depth below each surface were slower to respond. Even after several days with air temperature remaining below $0{ }^{\circ} \mathrm{C}$, temperature in the bottom layers declined but remained above freezing (fig. 18).
The patterns in temperature illustrated in figure 18 indicate that in the winter, permeable pavement may have certain advantages over impermeable asphalt pavement. Meltwater infiltrates into deeper layers of a permeable pavement system once air temperature goes above freezing, thereby preventing formation of ice on the pavement surface. This conclusion could potentially influence the way snow and ice are managed in areas where deicing salt application is the primary form of treatment for paved surfaces. This same conclusion was reached by Houle and others (2009), who suggested up to 75 percent less road salt was needed for PA to maintain equivalent or better traction as a reference impermeable asphalt lot. The reduced need of road salt was attributed to the well-drained nature of the reservoir base (Houle and others, 2009). More research is needed to better quantify the reduced need for road salt and other deicing agents on permeable pavements. 
Figure 18. Typical response to changing air temperature at 0 (top), 6 (middle), and 12 (bottom) inches below the porous asphalt, pervious concrete, and permeable interlocking pavers surfaces during winter.
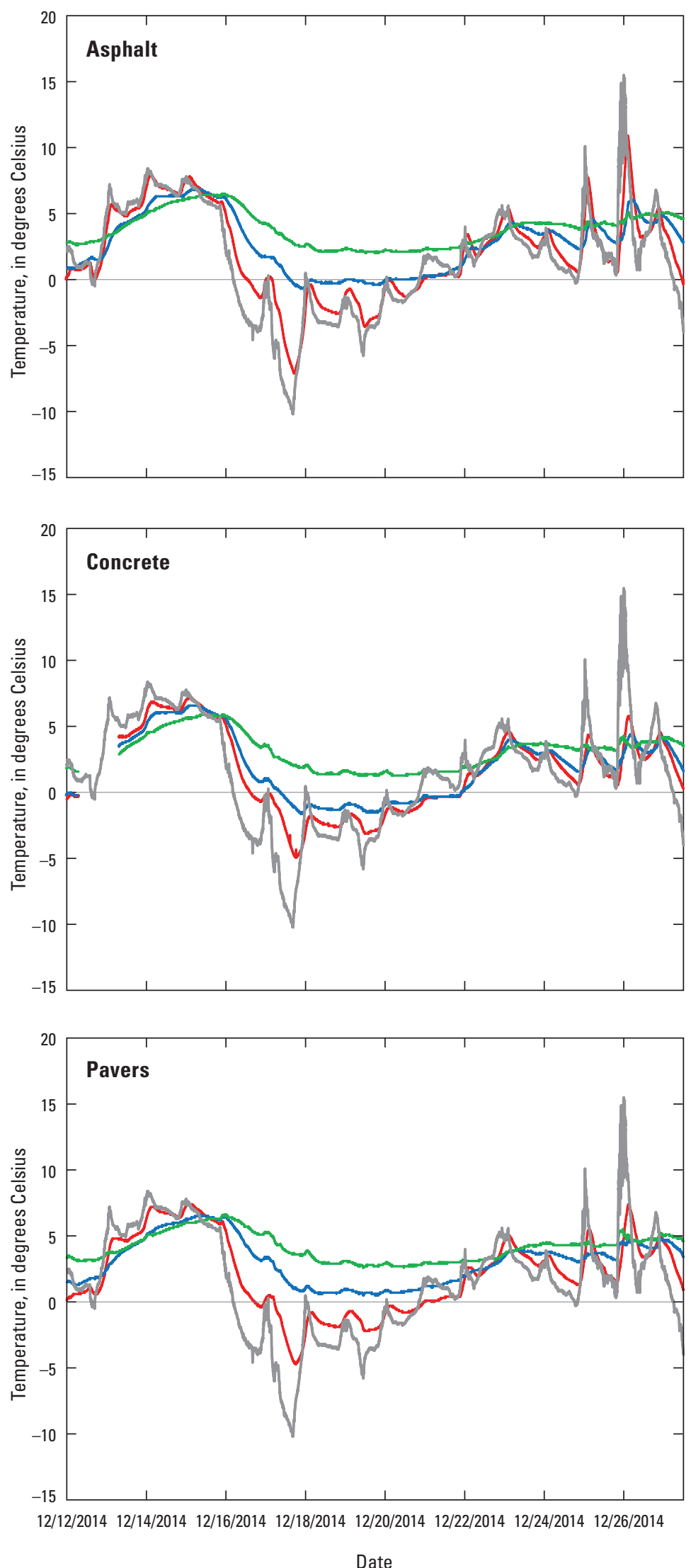


\section{Summary and Conclusions}

The U.S. Geological Survey evaluated the hydraulic, water-quality, and temperature performance of three permeable pavement systems during a 2-year period in Madison, Wisconsin. Stormwater runoff from an asphalt parking lot was routed to one of three test plots containing porous asphalt (PA), pervious concrete (PC), and permeable interlocking pavers (PIP). The drainage area of the parking lot was about 10 times larger than the receiving permeable pavement test area. Although this ratio is larger than most applications, the ratio provided an abundance of stormwater volume and sediment load to accelerate the rate of clogging for each permeable surface and an opportunity to assess how maintenance influenced performance. Each test plot was lined with an impermeable membrane to allow for measurement of runoff that would infiltrate through the permeable surface and underlying aggregate to an underdrain or bypass as overflow.

Despite the large ratio of draining to receiving area, all permeable surfaces were initially able to infiltrate most of the runoff. During several months, the infiltration rate gradually decreased as void space within each test plot filled with sediment and debris carried by successive precipitation events. PA, having the largest void space, was able to infiltrate runoff at a faster rate and during a longer period before signs of clogging were present. PIP similarly performed well after construction, despite the lowest percentage of void space of the three permeable surfaces. For PIP, signs of clogging were present after approximately 1 year, much sooner than for PA. Closer examination of the aggregate between paver joints indicated that much of the sediment entrained in runoff was captured within 1 inch of the surface. Most of the runoff in the PC test plot bypassed as overflow with only one-quarter of all flow infiltrating through to the underdrain. This result is mostly due to irregular surface elevations causing preferential clogging of low spots.

Maintenance efforts to restore the infiltrative capacity of each surface produced mixed results. The shallow penetration of solids in the PIP test plot indicates that infiltration rates can be improved through removal and replacement of the joint aggregate, whereas sediment captured by PA and PC seem to reside deeper into the permeable surface, outside the reach of commonly used maintenance practices. This result was determined by an appreciable increase in infiltration rates recorded in the PIP test plot after several passes by a vacuum street cleaner, whereas little to no change was measured in PA and PC. These permeable surfaces may benefit from maintenance practices that are better able to penetrate deeper into void spaces where sediment seems to be retained, such as removal of surface layers through milling or combining high-pressure washing with vacuum suction.

The large drainage area and high rate of sediment loading to the permeable test plots resulted in rapid clogging. PC and PIP were effectively impermeable about 1 year after construction. The decrease in infiltration rates is an indicator of sediment removal efficiency. PC had the highest sediment removal efficiency and was the first to clog. Similarly, PA was better able to infiltrate runoff during a longer period with mean infiltration rates exceeding 100 inches per hour 20 months after construction, but PA also had the lowest total suspended solids removal efficiency. Much of the clogging occurs in the spring when early precipitation events clean asphalt surfaces of residual sediment that accumulates during the winter. Subsequent precipitation events through summer and fall continue to deliver sediment to the permeable pavement test plots but with less of a cumulative impact. In addition to sediment, early spring rainfall delivers elevated concentrations of chloride from prior applications of deicing agents through the winter. Chloride has been determined to have some influence on the deflocculation of solids previously captured and retained in the permeable pavement through what is known as the sodium adsorption ratio effect. Therefore, the efficiency and longevity of permeable pavement could be extended through simple preventative measures such as timely removal of accumulated sediment on contributing surfaces by use of street cleaners after the last snowmelt and before the first spring rainfall.

Each permeable pavement was capable of reducing sediment and sediment-bound pollutants but lacked treatment processes needed to reduce dissolved pollutants, particularly chloride and dissolved phosphorus. Some of the net export of dissolved phosphorus may have come from unaccounted sources such as atmospheric deposition and the accumulation of organic detritus on the pavement surface. The removal of dissolved-phase pollutants is often difficult without specialized filter media or the addition of coagulants to improve settling. Permeable pavements have the potential to include such additives but would require additional testing to validate improved removal efficiencies. Therefore, minimizing export of dissolved pollutants might best be accomplished through source control such as locating permeable pavement systems away from areas with dense overhead tree canopy or the reduced application of road salt in winter.

Temperatures below each permeable surface generally followed diurnal changes in air temperature with a more gradual response observed in deeper layers. During summer, runoff filtering through permeable pavement may not be appreciably cooled because the temperature of runoff from the parking lot seems to be mostly controlled by ambient air temperature with only slight increases after daytime heating. The absorption of heat at depth by each permeable pavement, although initially reduced by the onset of runoff, was enough to sustain temperatures above what was measured from the parking lot. The absorption of heat was also observed during winter, allowing deeper layers to remain above freezing when air temperature was well below freezing, sometimes for several days. Although ambient subsurface temperatures of PA, PC, and PIP were not enough to melt snow or ice that had accumulated on the surface, void spaces did remain open. The open void spaces promoted infiltration of melting ice and snow as air temperatures once again rose above freezing. This melting of ice and snow could potentially reduce the need for application of deicing agents in winter because melted snow 
and ice would infiltrate below the surface thereby preventing refreezing of pooled water in what is known as the "black ice" effect. Additional research is needed to quantify application rates for deicing agents on permeable pavements that balance environmental protection and traffic safety.

\section{References Cited}

American Society of Testing and Materials, 2002, ASTM C33-02a-Standard specification for concrete aggregates: West Conshohocken, Pa., American Society of Testing and Materials International, accessed November 16, 2017, at https://www.astm.org/DATABASE.CART/HISTORICAL/ C33-02.htm.

American Society of Testing and Materials, 2009, ASTM C1701/C1701M-Standard test method for infiltration rate of in place pervious concrete: West Conshohocken, Pa., American Society of Testing and Materials International, accessed November 17, 2017, at https://www.astm.org/Standards/C1701.htm.

American Society of Testing and Materials, 2013, D397797- Standard test methods for determining sediment concentration in water samples: West Conshohocken, Pa., American Society of Testing and Materials International, accessed November 17, 2017, at http://www.doc88.com/p1824503598341.html.

Balades, J.-D., Legret, M., and Madiec, H., 1995, Permeable pavements - Pollution management tools: Water Science \& Technology, v. 32, no. 1, p. 49-56, accessed November 16, 2017, at https://doi.org/10.1016/0273-1223(95)00537-w.

Bannerman, R.T., Owens, D.W., Dodds, R.B., and Hornewer, N.J., 1993, Sources of pollutants in Wisconsin stormwater: Water Science and Technology, v. 28, no. 3-5, p. 241-259.

Barrett, M.E., 2008, Effects of a permeable friction course on highway runoff: Journal of Irrigation and Drainage Engineering, v. 134, no. 5, p. 646-651, accessed November 16, 2017, at https://doi.org/doi:10.1061/(ASCE)07339437(2008)134:5(646).

Bean, E.Z., Hunt, W.F., and Bidelspach, D.A., 2007, Evaluation of four permeable pavement sites in eastern North Carolina for runoff reduction and water quality impacts: Journal of Irrigation and Drainage Engineering, v. 133, no. 6, p. 583-592, accessed November 16, 2017, at https:// doi.org/doi:10.1061/(asce)0733-9437(2007)133:6(583).

Borris, Matthias, Viklander, Maria, Gustafsson, Anna-Maria, and Marsalek, Jiri, 2013, Modelling the effects of changes in rainfall event characteristics on TSS loads in urban runoff: Hydrological Processes, v. 28, no. 4, p. 1787-1796, accessed November 17, 2017, at https://doi.org/10.1002/ hyp. 9729.
Brattebo, B.O., and Booth, D.B., 2003, Long-term stormwater quantity and quality performance of permeable pavement systems: Water Research, v. 37, no. 18, p. 4369-4376, accessed November 17, 2017, at https://doi.org/10.1016/ S0043-1354(03)00410-X.

Brown, Chris, Chu, Angus, van Duin, Bert, and Valeo, Caterina, 2009, Characteristics of sediment removal in two types of permeable pavement: Water Quality Research Journal of Canada, v. 44, no. 1, p. 59-70.

Brown, R.A., and Borst, Michael, 2015a, Quantifying evaporation in a permeable pavement system: Hydrological Processes, v. 29, no., 9, p. 2100-2111, accessed November 17, 2017, at https://doi.org/10.1002/hyp.10359.

Brown, R.A., and Borst, Michael, 2015b, Nutrient infiltrate concentrations from three permeable pavement types: Journal of Environmental Management, v. 164, p. 74-85, accessed November 17, 2017, at http://doi.org/10.1016/j. jenvman.2015.08.038.

Chopra, Manoj, Kakuturu, Sai, Ballock, Craig, Spence, Joshua, and Wanielista, Marty, 2010, Effect of rejuvenation methods on the infiltration rates of pervious concrete pavements: Journal of Hydrologic Engineering, v. 15, no. 6, p. 426-433, assessed November 17, 2017, at https://doi. org/10.1061/(ASCE)HE.1943-5584.0000117.

Collins, K.A., Hunt, W.F., and Hathaway, J.M., 2008, Hydrologic comparison of four types of permeable pavement and standard asphalt in Eastern North Carolina: Journal of Hydrologic Engineering, v. 13, no. 12, p. 1146-1157, accessed November 17, 2017, at https://doi.org/10.1061/ (ASCE)1084-0699(2008)13:12(1146).

Deitz, M.E., 2007, Low impact development practices-A review of current research and recommendations for future directions: Water, Air, and Soil Pollution, v. 186, no. 1-4, p. 351-363, accessed November 17, 2017, at https://doi. org/10.1007/s11270-007-9484-z.

Dierkes, Carsten, Kuhlmann, Lothar, Kandasamy, Jaya, and Angelis, George, 2002, Pollution retention capability and maintenance of permeable pavements in International Conference on Urban Drainage, 9th, Portland, Oreg., 2002, Proceedings: Reston, Va., American Society of Civil Engineers, 13 p., accessed November 17, 2017, at https://doi. org/10.1061/40644(2002)40.

Drake, Jennifer, Bradford, Andrea, and Van Seters, Tim, 2014a, Stormwater quality of spring-summer-fall effluent from three partial-infiltration permeable pavement systems and conventional asphalt pavement: Journal of Environmental Management, v. 139, p. 69-79, accessed November 17, 2017, at https://doi.org/10.1016/j.jenvman.2013.11.056. 
Drake, Jennifer, Bradford, Andrea, and Van Seters, Tim, 2014b, Winter effluent quality from partial-infiltration permeable pavement systems: Journal of Environmental Engineering, v. 140, no. 11, 13 p., accessed November 17, 2017, at https://doi.org/10.1061/(ASCE)EE.1943-7870.0000854.

Eaton, A. D., Clesceri, L. S., Greenberg, A. E., Franson, M. A. H., 1998, Standard methods for the examination of water and wastewater, Washington, DC, American Public Health Association.

Eisenberg, Bethany, Lindow, K.C., and Smith, D.R., eds., 2015, Permeable pavements: Reston, Va., American Society of Civil Engineers, 249 p.

Fassman, E.A., and Blackbourn, Samuel, 2010, Urban runoff mitigation by a permeable pavement system over impermeable soils: Journal of Hydrologic Engineering, v. 15, no. 6, p. 475-485, accessed November 17, 2017, at https://doi. org/10.1061/(ASCE)HE.1943-5584.0000238.

Gilbert, J.K., and Clausen, J.C., 2006, Stormwater runoff quality and quantity from asphalt, paver, and crushed stone driveways in Connecticut: Water Research, v. 40, no. 4, p. 826-832, accessed November 17, 2017, at https://doi. org/10.1016/j.watres.2005.12.006.

Hathaway, J.M., Hunt, W.F., and Jadlocki, S., 2009, Indicator bacteria removal in stormwater best management practices in Charlotte, North Carolina: Journal of Environmental Engineering, v. 135, no. 12, p. 1275-1285, accessed November 17, 2017, at https://doi.org/10.1061/(ASCE) EE.1943-7870.0000107.

Helsel, D.R., 2005, Nondetects and data analysis-Statistics for censored environmental data: New York, John Wiley and Sons, $250 \mathrm{p}$.

Helsel, D.R., and Hirsch, R.M., 2002, Statistical methods in water resources: U.S. Geological Survey Techniques of Water Resources Investigations, book 4, chap. A3, 522 p., accessed November 17, 2017, at https://pubs.usgs.gov/twri/ twri4a3/.

Houle, K.M., Roseen, R.M., Ballestero, T.P., Briggs, J.F., and Houle, J.J., 2009, Examinations of pervious concrete and porous asphalt pavements performance for stormwater management in northern climates, in Low Impact Development International Conference, May 17-21, San Francisco, Calif., 2010, Proceedings: Kansas City, Mo., World Environmental and Water Resources Congress, accessed November 17, 2017, at http://ascelibrary.org/doi/ abs/10.1061/41099\%28367\%29111.

Kakuturu, S.P., and Clark, S.E., 2015, Effects of deicing salts on the clogging of stormwater filter media and on the media chemistry: Journal of Environmental Engineering, v. 141, no. 9, 7 p., accessed November 17, 2017, at https://doi. org/10.1061/(ASCE)EE.1943-7870.0000927.
Leisenring, M., Clary, J., and Hobson, P., 2014, International stormwater best management practices (BMP) databasePollutant category statistical summary report: accessed March 21, 2017, at http://www.bmpdatabase.org.

Lucke, Terry, and Beecham, Simon, 2011, Field investigation of clogging in a permeable pavement system: Building Research and Information, v. 39, no. 6, p. 603-615, accessed November 17, 2017, at https://dx.doi.org/10.1080/ 09613218.2011.602182.

Mata, L.A., 2008, Sedimentation of pervious concrete pavement systems: Raleigh, North Carolina State University, Ph.D. dissertation, 267 p., accessed October 19, 2017, at http://www.lib.ncsu.edu/resolver/1840.16/5749.

Meyer, J.L., Paul, M.J., and Taulbee, W.K., 2005, Stream ecosystem function in urbanizing landscapes: Journal of North American Benthological Society, v. 24, no. 3, p. 602-612, accessed November 17, 2017, at http://www.bioone.org/doi/ abs/10.1899/04-021.1.

Minnesota Pollution Control Agency, 2017, Minnesota stormwater manual-Design criteria for permeable pavement: Minnesota Pollution Control Agency web page, accessed June 26, 2017, at https://stormwater.pca.state.mn.us/index. php/Design_criteria_for_permeable_pavement.

Mitchell, J.K., and Soga, Kenichi, 2005, Fundamentals of soil behavior (3d ed.): Hoboken, N.J., Wiley, 592 p.

Mohanty, S.K., Torkelson, A.A., Dodd, Hanna, Nelson, K.L., and Boehm, A.B., 2013, Engineering solutions to improve the removal of fecal indicator bacteria by bioinfiltration systems during intermittent flow of stormwater: Environmental Science and Technology, v. 47, no. 19, p. 10791-10798, accessed November 17, 2017, at https://doi.org/10.1021/ es305136b.

National Oceanic and Atmospheric Administration, 2016, 1981-2010 station normal of temperature, precipitation, and heating and cooling degree days, Charmany Farm, Wisconsin.

Oke, T.R., 1982, The energetic basis of the urban heat island: Quarterly Journal of the Royal Meteorological Society, v. 108 , no. 455 , p. 1-24, accessed November 17, 2017, at https://doi.org/10.1002/qj.49710845502.

Pitt, Robert, Clark, Shirley, and Field, Richard, 1999, Groundwater contamination potential from stormwater infiltration practices: Urban Water, v. 1, no. 3, p. 217-236, accessed November 17, 2017, at https://doi.org/10.1016/ s1462-0758(99)00014-x.

Qin, Yinghong, 2015, A review on the development of cool pavements to mitigate urban heat island effect: Renewable and Sustainable Energy Reviews, v. 52, p. 445-459, accessed November 17, 2017, at https://doi.org/10.1016/j. rser.2015.07.177. 
Roa-Espinosa, A., Wilson, T.B., Norman, J.M., and Johnson, Kenneth, 2003, Predicting the impact of urban development on stream temperature using a thermal urban runoff model (TURM) in The National Conference on Urban Stormwater-Enhancing Programs at the Local Level, Proceedings: U. S. Environmental Protection Agency, National Risk Management Research Laboratory, p. 369-389, accessed December 28, 2017, at http://www.colowqforum.org/pdfs/ listing-methodology/10-2014/WQCD\%2020141001\%20 Roa-Espinosa\%20et\%20al\%202003\%20Article.pdf.

Roseen, R.M., Houle, James, Ballestero, T.P., and Puls, Timothy, 2010, Pre-construction, construction, and postconstruction monitoring report for Greenland Meadows for July 2007-October 2010: Durham, N.H., The University of New Hampshire Stormwater Center, 15 p., accessed January 5, 2018, at https://www.unh.edu/unhsc/sites/unh.edu.unhsc/ files/docs/2010\%20UNH\%20SC_Packard\%20Monitoring\%20interim\%20report_final.b.pdf.

Roseen, R.M., Ballestero, T.P., Houle, J.J., Briggs, J.F., and Houle, K.M., 2012, Water quality and hydrologic performance of a porous asphalt pavement as a storm-water treatment strategy in a cold climate: Journal of Environmental Engineering, v. 138, no. 1, p. 81-89, accessed November 17, 2017, at https://doi.org/10.1061/(asce)ee.19437870.0000459 .

Roseen, R.M., Ballestero, T.P., Houle, K.M., Heath, Douglas, and Houle, J.J., 2014, Assessment of winter maintenance of porous asphalt and its function for chloride source control: Journal of Transportation Engineering, v. 140, no. 2, 8 p., accessed November 17, 2017, at https://doi.org/10.1061/ (ASCE)TE.1943-5436.0000618.

Sansalone, J., Kuang, X., Ying, G., and Ranieri, V., 2012, Filtration and clogging of permeable pavement loaded by urban drainage: Water Research, v. 46, no. 20 , p. 6763-6774, accessed November 17, 2017, at https://doi. org/10.1016/j.watres.2011.10.018.

Selbig, W.R., 2018, Storm characteristics, concentrations, and loads measured at the permeable pavement research facility, Madison, Wisconsin, 2014-16: U.S. Geological Survey data release, https://doi.org/10.5066/F7RX9B09.

Schiff, K.C., Tiefenthaler, L.L., Bay, S.M., and Greenstein, D.J., 2016, Effects of rainfall intensity and duration on the first flush from parking lots: Water, v. 8, no. 8, 10 p., accessed November 17, 2017, at http://www.mdpi. com/2073-4441/8/8/320.

Tota-Maharaj, Kiran, and Scholz, Miklas, 2010, Efficiency of permeable pavement systems for the removal of urban runoff pollutants under varying environmental conditions: Environmental Progress and Sustainable Energy, v. 29, no. 3, p. 358-369, accessed November 17, 2017, at https:// doi.org/10.1002/ep.10418.
University of New Hampshire Stormwater Center, 2012, Biennial report: Durham, N.H., 36 p., accessed March 22, 2017, at http://www.unh.edu/unhsc/sites/unh.edu.unhsc/files/docs/ UNHSC.2012Report.10.10.12.pdf.

U.S. Environmental Protection Agency, 1983, Results of the Nationwide Urban Runoff Program - Volume 1-Final report: Washington D.C., Water Planning Division, National Technical Information Service PB84-185552 [variously paginated].

U.S. Environmental Protection Agency, 1993, Methods for the determination of inorganic substances in environmental samples: Environmental Monitoring Systems Laboratory, EPA 600/R-93/100, 18 p.

U.S. Environmental Protection Agency, 2003, Guidelines establishing test procedures for the analysis of pollutants; analytical methods for biological pollutants in ambient water; final rule: Federal Register, v. 68, no. 139, 13 p., accessed January 26, 2017, at https://www.federalregister. gov/d/03-18155.

U.S. Environmental Protection Agency, 2012a, National recommended water quality criteria-Aquatic life criteria table: accessed April 27, 2017, at https://www.epa.gov/wqc/ national-recommended-water-quality-criteria-aquatic-lifecriteria-table.

U.S. Environmental Protection Agency, 2012b, Recreational water quality criteria: Office of Water 820-F-12-058, accessed April 27, 2017, at https://www.epa.gov/sites/production/files/2015-10/documents/rwqc2012.pdf.

Van Seters, T., 2007, Performance evaluation of permeable pavement and a bioretention swale-Seneca College, King City, Ontario: Downsview, Ontario, Toronto and Region Conservation Authority, Interim Report 3, 71 p., accessed December 28, 2017, at https://www.icpi.org/sites/default/ files/Seneca\%20College\%20TRCA\%202007\%20report.pdf.

Wahyuni, E.A., 2015, The influence of $\mathrm{pH}$ characteristics on the occurance of coliform bacteria in Madura Strait: Procedia Environmental Sciences, v. 23, p. 130-135, accessed November 17, 2017, at https://doi.org/10.1016/j. proenv.2015.01.020.

Wallace, T.A., Ganf, G.G., and Brookes, J.D., 2008, A comparison of phosphorus and DOC leachates from different types of leaf litter in an urban environment: Freshwater Biology, v. 53, no. 9, p. 1902-1913, accessed November 17, 2017, at http://onlinelibrary.wiley.com/doi/10.1111/j.13652427.2008.02006.x/abstract. 
Walsh, C.J., Roy, A.H., Feminella, J.W., Cottingham, P.D., Groffman, P.M., and Morgan II, R.P., 2005, The urban stream syndrome - Current knowledge and the search for a cure, Journal of the North American Benthological Society, v. 24, no. 3, p. 706-723, accessed November 17, 2017, at http://www.bioone.org/doi/full/10.1899/04-028.1.

Wardynski, B.J., Winston, R.J., and Hunt, W.F., 2013, Internal water storage enhances exfiltration and thermal load reduction from permeable pavement in the North Carolina mountains: Journal of Environmental Engineering, v. 139, no. 2, p. 187-195, accessed November 17, 2017, at https:// doi.org/10.1061/(ASCE)EE.1943-7870.0000626.

Warrence, N.J., Bauder, J.W., and Pearson, K.E., 2003, Basics of salinity and sodicity effects on soil physical properties: Montana State University, Land Resources and Environmental Sciences Department, accessed March 21, 2017, at http://www.soilzone.com/Library/Salinity/.

Winston, R.J., Davidson-Bennet, K.M., Buccier, K.M., and Hunt, W.F., 2016a, Seasonal variability in stormwater quality treatment of permeable pavements situated over heavy clay and in a cold climate: Water, Air, \& Soil Pollution, v. 227, no. 140, 21 p., accessed November 17, 2017, at https://doi.org/10.1007/s11270-016-2839-6.
Winston, R.J., Al-Rubaei, A.M., Blecken, G.T., Viklander, M., and Hunt, W.F., 2016b, Maintenance measures for preservation and recovery of permeable pavement surface infiltration rate - The effects of street sweeping, vacuum cleaning, high pressure washing, and milling: Journal of Environmental Management, v. 169, p. 132-144, accessed November 17, 2017, at http://dx.doi.org/10.1016/j.jenvman.2015.12.026.

Wisconsin Administrative Code, 2002, Runoff management, chap. NR 151.00: accessed July 30, 2017, at http://docs. legis.wisconsin.gov/code/admin_code/nr/100/151/II/01.

Wisconsin Administrative Code, 2010, Water quality standards for Wisconsin surface waters, Chapter NR102.06 Phosphorus: accessed April 25, 2017, at: https://docs.legis.wisconsin.gov/code/admin_code/nr/100/102/I/06.

Wisconsin Department of Natural Resources, 2016, Stormwater post-construction technical standards for permeable pavement (1008): accessed December 19, 2016, at http:// dnr.wi.gov/topic/Stormwater/standards/postconst_standards. html. 
For additional information contact:

Director, Upper Midwest Water Science Center U.S. Geological Survey

8505 Research Way

Middleton, WI 53562

Publishing support provided by the Madison and Rolla Publishing Service Centers 
